\title{
Judicial Federalism and the Administrative States
}

\author{
Ann Woolhandler $\dagger$ \\ Michael G. Collins
}

\section{TABLE OF CONTENTS}

Introduction

I. Federal Courts and the Pre-Administrative States.

A. Federal Judicial Review of Pre-Modern "Agencies":

Scrutinizing Local Governinent Power.

1. Municipal Financing.

2. Local Powers of Eminent Domain.

B. Federal Judicial Review of Early State Rate-Setting Agencies.

1. Policing Delegation of Rate-Setting Authority

2. Policing Rate Reasonableness.

C. Local Governments and Early State Agencies:

The Parallels.

1. Lack of Uniform Outcomes.

2. Lack of Deference to Party Structure or Standards of Review.

3. Differentiating Administrative and Judicial Process...637

4. Forum Restrictions and Diversity as a "Constitutional Right".

II. Federal Courts and Modern State Agencies.

A. Recasting Judicial Federalisin.

1. Statutory Limits on the Federal Courts

2. Judge-Made Abstention Doctrines

Copyright (C) 1999 California Law Review, Inc.

$\dagger \quad$ Professor of Law, Tulane Law School. J.D., Harvard; B.A., Yale.

$\pm \quad$ Professor of Law, Tulane Law School. J.D., Harvard; B.A., Pomona College. The authors would like to thank Richard Fallon, Barry Friedman, Johnathan Gutoff, John Jeffries, John Kramer, Richard McAdams, Richard Matasar, Daniel Meltzer, Michael Wells, Keith Werhan, Larry Yackle, and participants in the Boston University Faculty Workshop for their suggestions and comments on earlier drafts. 
B. Shifting Background Assumptions.................................646

1. The Retreat from Economic Due Process.................647

2. The Decline of the General Common Law .................648

3. Commingling Court and Agency Functions...............650

III. State-Law Challenges to Agency Action in the

Federal Courts

A. Federalism and Jurisdiction

B. Erie's Impact on Judicial Review of State Agency

Action

1. Deferential Review as "Policy Making"... .657

2. Deferential Review as "Appellate" Process. .660

C. Uniformity's Limits and the Role of Diversity .667

1. Lawmaking by Judgment Versus Lawmaking by Legislation. .668

2. Abstention and Judgments with Class-Wide Fallout ...672

3. Risks of Error and the Federal Forum. .674

IV. Federal-Law Challenges to State Agency Action in the Federal Courts

A. Challenges Implicating Administrative Unreasonableness 682

1. Ad Hoc Denials of Nonfundamental Rights .682

2. Systemic Denials and Legislation .686

B. Challenges Beyond Administrative Unreasonableness 687

C. The Impact of Complexity and Specialization. 690

1. Uniformity and Agency Fact-Finding .690

2. Fimality and Agency Adjudication .694 


\title{
Judicial Federalism and the Administrative States
}

\author{
Ann Woolhandler \\ Michael G. Collins
}

Federal courts are reluctant to review the work of state and local administrative agencies. Despite the presence of diversity or federal question jurisdiction to challenge final agency action, federal courts have sometimes abstained from exercising their jurisdiction out of fear of disrupting a complex regulatory scheme and displacing state courts in the uniform development of state regulatory policy. At other times, federal courts have treated review of state administrative action as "appellate" in nature and therefore beyond the jurisdiction of the federal district courts, especially when review of agency action would be deferential under state law. And at still other times, federal courts have invoked preclusion principles to bar federal challenges to agency action that was judicial in nature. While recent decisions of the Supreme Court may have moved away from imposing a jurisdictional bar, the American Law Institute proposes to revive such a limit, arguing that such review of agency action is contrary to the historic role of the federal courts and would alter their essential function as courts of original jurisdiction.

In this Article, Professors Woolhandler and Collins challenge these various practices preventing review of nonfederal administrative action, and they question the rationales behind them. They argue that, as a historical matter, federal courts once engaged in a robust review of state administrative action, even as to issues of state law. In addition, they suggest that concern for federal court interference with uniformity of state policy making has been overstated, while traditional concerns of federal jurisdictional policy in providing a neutral forum for out of staters as well as those raising federal challenges to state and local action, have been slighted. They also attack the characterization of judicial review of administrative action as appellate, and suggest why it is both descriptively accurate and normatively desirable to see judicial review as an original proceeding distinct from agency action. And in many cases, they observe, according state agency decision making the same level of deference that it would obtain in a state court would serve as a better measure of the respect owed such decision making than formal preclusion. Although the Article takes the position that federal 
courts should not shy from entertaining diversity-based challenges to state administrative decision making, or even most challenges grounded in federal law, it concludes that, absent diversity, due process reasonableness challenges to agency action should ordinarily be relegated to state courts.

\section{INTRODUCTION}

Judicial review of agency action is a fixture of the modern administrative state. Federal courts regularly review the work of federal agencies, and state courts review the work of state agencies. The scope of judicial review depends on the respective powers that have been given to the courts and agencies within each system, subject to constitutional limits. But in our federal scheme of government, it is also possible for federal courts to sit in review of state administrative action and substitute their own judicial review for the review that would otherwise take place in the state courts. If the prerequisites of federal jurisdiction are present at the point of judicial involvement, then challenges to state agency action-whether based on state or federal law-could theoretically take place in either system.

It is precisely this prospect that has given the Supreme Court pause, at least since the New Deal. Beginning with Burford v. Sun Oil Co., ${ }^{1}$ the Court has attempted to work out principles of administrative abstention and related doctrines to curtail federal court review of state agency action, despite federal question or diversity jurisdiction having been properly invoked. ${ }^{2}$ In so doing, the Court has developed perhaps the most

1. 319 U.S. 315 (1943).

2. Federal courts scholars have usually considered administrative abstention and related issues surrounding federal court review of state agency action in connection with abstention more generally. See, e.g., Randall P. Bezanson, Abstention: The Supreme Court and Allocation of Judicial Power, 27 VAND. L. REv. 1107, 1120-27 (1974); Bradford R. Clark, Ascertaining the Laws of the Several States: Positivism and Judicial Federalism After Erie, 145 U. PA. L. REv. 1459, 1517-34 (1997); David P. Currie, The Federal Courts and the American Law Institute (Part II), 36 U. CH1. L. Rev. 268, 311-19 (1969); Julie A. Davies, Pullman and Burford Abstention: Clarifying the Roles of State and Federal Courts in Constitutional Cases, 20 U.C. DAvis L. REv. 1, 11-15 (1986); Martha A. Field, Abstention in Constitutional Cases: The Scope of the Pullman Abstention Doctrine, 122 U. PA. L. REv. 1071, 1153-63 (1974); Barry Friedman, A Revisionist Theory of Abstention, 88 Mich. L. Rev. 530, 584-87 (1989); James C. Rehnquist, Taking Comity Seriously: How to Neutralize the Abstention Doctrine, 46 STAN. L. Rev. 1049, 1075-79 (1994); Michael Wells, The Role of Comity in the Law of Federal Courts, 60 N.C. L. REv. 59, $75-78$ (1981); Charles Alan Wright, The Abstention Doctrine Reconsidered, 37 TEx. L. REv. 815, 819-22 (1959). For more specific attention to Burford, see Gordon G. Young, Federal Court Abstention and State Administrative Law from Burford to Ankenbrandt: Fifty Years of Judicial Federalism under Burford v. Sun Oil Co. and Related Doctrines, 42 DePaUl L. Rev. 859 (1993); see also William E. Ryckman, Jr., Land Use Litigation, Federal Jurisdiction, and the Abstention Doctrines, 69 CALIF. L. REV. 377 (1981); Charles S. Treat, Commcnt, Abstention by Federal Courts in Suits Challenging State Administrative Decisions: The Scope of the Burford Doctrine, 46 U. CHI. L. REv. 971 (1979). 
amorphous and unwieldy of its judge-crafted abstention doctrines. ${ }^{3}$ Further complicating the picture is the Court's suggestion that federal courts may be barred jurisdictionally from considering a challenge to state agency action that would be considered an "appeal" under state law. ${ }^{4}$ The imprecision (and infrequency) of the Court's attempted formulations in these related areas has led many lower federal courts and commentators to suppose that federal courts ordinarily should not be in the busmess of reviewing state agency decision making at all, no matter what the nature of the legal challenge. ${ }^{5}$ The recent decision in City of Chicago v. International College of Surgeons, ${ }^{6}$ in which the Court upheld supplemental jurisdiction over a state-law challenge to local agency action but equivocated over abstention, shows that the Court continues to struggle with the perceived difficulties raised by federal court review of state administrative action.

Objections to entertaining state-law challenges to agency action are grounded $\mathrm{m}$ fears that lower federal courts will be too involved in the shaping of state law and thus create problems of nonuniformity and illegitimacy. ${ }^{7}$ In addition, if a state's judiciary typically accords deference to state agency decision making, then federal courts might be cast in an inappropriate appellate posture when reviewing state agency action. ${ }^{8}$ Other objections (applicable even to federal-law challenges to agency action) are sometimes directed to federal court involvement in factintensive matters concerning which state agencies and state courts may have developed expertise. ${ }^{9}$ Related concerns have led the Court to

3. See, e.g., Richard H. FAllon, JR., et al., HART \& WechsleR's The Federal Courts AND THE FEDERAL SYSTEM 1252 (4th ed. 1996) [hereinafter HART \& WechSLER] (noting confusion in lower courts in applying administrative abstention); Field, supra note 2, at 1153-63 (criticizing administrative abstention's lack of coherence).

4. See Chicago, Rock Island \& Pac. R.R. Co. v. Stude, 346 U.S. 574 (1954). For a discussion of Stude, see infra text accoinpanying notes 191-194.

5. See 1 Federal Courts Study Commttee, Working Papers and Subcommittee REPORTS 614-15 (1990) [hereinafter FEDERAL CoURTS STUDY] ("[The Court's] expansive language has led inany courts of appeals dramatically to expand [the] Burford doctrine by ordering abstention simply because state administrative action was challenged."). Professor Erwin Chemerinsky has noted that lower courts appear to take vastly different approaches to abstention in the face of agency decision making, some of them upholding dismissal when there is scant evidence of interference with a state's regulatory programs. See ERWIN CHEMERINSKY, FEDERAL JuRISDICTION \$ 12.2.3, at 759 \& nn. 108-09 (3d ed. 1999). For discussion of the disarray in the lower federal courts, see Young, supra note 2, at 947; see also 17A Charles A. Wright et al., Federal Practice and Procedure $\S$ 4244, at 95-98 \& n.18 (1988); Treat, supra note 2, at 980-89. For lower court confusion respecting deferential-review actions, see cases cited infra note 128.

6. 118 S. Ct. 523 (1997).

7. This was a driving concern of Burford itself. See Burford v. Sun Oil Co., 319 U.S. 315, 32528 (1943); see also Bezanson, supra note 2, at 1122-23; Clark, supra note 2, at 1467-71.

8. See infra text accompanying notes 125-128, 188-219.

9. As the Court would later state, Burford requires federal courts not to "interfere with" state agency proceedings or orders when state court judicial review is available and when "the 'exercise of federal review of the question in a case and in similar cases would be disruptive of state efforts to 
fashion federal common-law rules of preclusion that can prevent federal courts from reassessing agency action based on policies of repose and respect for initial "judicial" decision makers. ${ }^{10}$

It is our contention that many of these concerns-particularly those respecting the threat of interference with state policy making and the jurisdictional difficulties of deferential review-are either not well taken or are greatly overstated. We suggest that legitimate state interests can be addressed effectively and better accommodated to Congress's jurisdictional grants through careful attention to state standards of review of agency action and a more narrowly tailored use of abstention.

In Part I of this Article, we address how the federal courts handled similar issues prior to these modern developments in federal courts law. It might be supposed-indeed some current members of the Supreme Court have supposed ${ }^{11}$-that problems of federal judicial review of agency action could not have existed before the rise of the modern administrative state. But in the nineteenth century, federal courts often faced analogous problems im reviewing actions taken by subordinate governmental entities, including early state administrative bodies. Their decisions, often in the exercise of diversity jurisdiction, reflect a strongly "Nationalist"12 approach to the problem of judicial review of agency action that paid little heed to modern concerns of judicial federalism. For example, federal courts reviewing state administrative action ignored various limits that would have applied to state court review, including party structure and standards of review. Also, much as they did under the now-discarded regime of Swift $v$. Tyson, ${ }^{13}$ federal courts often

establish a coherent policy with respect to a matter of substantial public concern." New Orleans Pub. Serv., Inc. v. Council of City of New Orleans, 491 U.S. 350, 361 (1989) (quoting Colorado River Water Conservation Dist. v. United States, 424 U.S. 800, 814 (1976)). As noted below, the Court sometimes offers a broader "definition" of this sort of abstention that is not specific to agency action. See infra note 239. Although the Court has suggested that similar principles may operate in nonadministrative contexts, see, e.g., Ankenbrandt v. Richards, 504 U.S. 689, 705-06 (1992), we focus on the problem of review of ageney decision making.

10. See, e.g., University of Tenn. v. Elliott, 478 U.S. 788 (1986); see also infra text accompanying notes $317-350$ (discussing and critiquing the preclusive consequences of agency decision making).

11. See City of Chicago v. International College of Surgeons, 118 S. Ct. 523, 534 (1997) (Ginsburg, J., jomed by Stevens, J., dissenting) (arguing that to allow federal courts to hear state-law claims involving deferential review of state agency action created an illegitimate and historically unfounded system of "cross-system appeals"). Based on a similar reading of the supposed "historic function" of the federal courts, the American Law Institute has proposed revision of the decision in College of Surgeons. See A.L.I., Federal Judicial Code Revision Project at xix-xx (Tentative Draft No. 2, 1998). We discuss the proposal infra note 218.

12. See Richard H. Fallon, Jr., The Ideologies of Federal Courts Law, 74 VA. L. REv. 1141, 1144-45 (1988) (describing a "Nationalist" model of federal courts law that posits a preference for federal over state courts as the guarantors of federal rights, and contrasting it with a "Federalist" model that is more state-respecting).

13. 41 U.S. (16 Pet.) 1 (1842), overruled by Erie R.R. v. Tompkins, 304 U.S. 64 (1938). 
slighted state substantive law and relied on government-limiting, property-protecting principles of "general constitutional law" to answer unclear questions of state administrative and constitutional law. These decisions provided a model for the later application of similar principles to the federal Constitution during the era of Lochner v. New York. ${ }^{14}$ More importantly from a modern perspective, in both general-law and federal-law challenges to agency action, the Supreme Court was careful to treat judicial review of agency action as separate from the administrative phase. Such review, in the Court's eyes, was an appropriate activity for federal trial courts and state courts alike. The Court consistently ignored states' attempts to limit review to state forums, thereby enabling federal courts to protect what the Court saw as a constitutional right to a neutral forum for out-of-staters and federal rights claimants.

In Part II, we attempt to account for the modern Court's large-scale retreat from its earlier willingness to have federal courts engage $\mathrm{m}$ judicial review of state administrative action. One reason for the retreat was linked to the New Deal's broader constitutional agenda of downsizing the judicial scrutiny associatcd with Lochner-era economic due process challenges to governmental action. This led not only to the marginalization of federal due process claims challenging the reasonableness of regulatory action, but also to sidelining nonfederal diversity claims that could provide parallel remedies. Another imfluence was the Court's rejection of general-law reasoning in favor of positivism, ${ }^{15}$ and this rejection's impact on state-federal relations. The Court's conclusion in Erie Railroad Co. v. Tompkins ${ }^{16}$ that state courts make law led the Court to emphasize uniformity in the interpretation of state law, and it also blurred the lines of separation of powers within and among state institutions. This, in turn, eroded the Court's earlier confidence as to when state administrative process ended and judicial process began-a determination that had long been critical for assessing not just the timing but the propriety of federal court intervention. The Court thus began to

14. 198 U.S. 45 (1905).

15. See Patrick J. Borchers, The Origins of Diversity Jurisdiction, the Rise of Legal Positivism, and a Brave New World for Erie and Klaxon, 72 TEx. L. REv. 79, 116-17 (1993) (noting that Erie embraced positivism, which "defined law as a command of a sovereign"); Lawrence Lessig, ErieEffects of Volume 110: An Essay on Context in Interpretive Theory, 110 HARv. L. REV. 1785, 179295 (1997) (noting the impact of the jurisprudential move from general-law reasoning to positivism in connection with Erie). Unlike the general law that was applied by the federal courts under Swift, positivism rcquired federal courts to locate the source of a legal rule in a particular sovereign. See infra text accompanying notes 147-149. Nevertheless, two scholars have recently questioned the degree to whicl the jurisprudential shift to positivism required Erie's holding that Swift was unconstitutional. See Jack Goldsmith \& Steven Walt, Erie and the Irrelevance of Legal Positivism, 84 VA. L. REV. 673 (1998); see also infra note 147 (discussing Erie and positivism).

16. 304 U.S. 64 (1938). 
view state courts reviewing state agencies as "working partners"17 with the agencies in formulating state policy, or alternatively, as sitting in appellate review of subordinate state judicial decision inakers-both arguably illegitimate roles for the federal trial courts.

In Parts III and IV, we attempt to offer a middle ground between these two historical extremes regarding federal trial court review of state agency action. Although the rise of positivism and the decline of economic due process have fundamentally altered the federal courts' relationship with the states and state courts, they do not call for the broad withdrawal of the federal courts from review of state admimistrative action as suggested by Burford and related decisions. Although federal courts may no longer have a legitimate imterest in fashioning general law (as opposed to federal law) there remains a legitimate federal interest in providing out-of-staters and federal rights claimants a fair foruin, for the resolution of disputed questions both of law and of fact.

\section{I}

\section{Federal Courts and the Pre-Administrative States}

Despite the absence of agencies of the modern type in the preregulatory era, federal courts often faced the problem of judicial review of state administrative action. State administrative authority was at issue when federal courts considered the powers of local governinental bodies such as cities and counties, of specially appointed commissions and juries, and, eventually, of early rate-setting agencies.

\section{A. Federal Judicial Review of Pre-Modern "Agencies": Scrutinizing Local Government Power}

Mumcipalities resemble modern agencies in that they are subordinate governmental bodies that operate within limits largely defined by the law of the sovereign that created them. State law defines both the law-making and law-enforcennent powers of cities. Moreover, as with modern agencies, ${ }^{18}$ separation of legislative and executive powers within municipal governments was less strictly observed than at the state and federal levels. Thus, older cases involving the scope of municipal powers illustrate how early federal courts dealt with issues of state administrative

17. Burford v. Sun Oil Co., 319 U.S. 315, 326 (1943). See generally Stephen Gardbaum, New Deal Constitutionalism and the Unshackling of the States, 64 U. CHI. L. REv. 483, 490 (1997) (noting that the basis of the New Deal revolution was a change in thinking about separation of powers, of which Erie and Burford were both a part). As Professor Gardbaum shows, the New Deal, which is usually associated with an expansion of federal govemmental power, actually resulted in a contraction of federal judicial power in both divcrsity cases and in substantive due process challenges to state action. See infra text accounpanying notes 139-162.

18. See infra text accompanying notes 153-162. 
law in ways that are fundamentally at odds with the Supreme Court's current approach.

\section{Municipal Financing}

A group of mineteenth century decisions involving inunicipal financing and bond defaults illustrates the federal courts' earlier, nondeferential attitude toward state-created agencies-even with respect to questions of state law. ${ }^{19}$ Soinetimes these cases implicated federal constitutional issues, as when state legislatures repudiated or impaired existing municipal debts. Even before the advent of general federal question jurisdiction, aggrieved out-of-state bondholders used federal court diversity jurisdiction to raise violations of the Contract Clause.$^{20}$ In fact, the Supreme Court interpreted diversity jurisdiction expansively during this period to accommodate litigants who raised such constitutional issues. ${ }^{21}$

More often, however, the municipalities' partners in repudiation were not state Iegislatures but state courts. When creditors attempted to collect, some state courts convemiently concluded that the municipality had no power under the state constitution to issue bonds in the first place. ${ }^{22}$ In that event, bondholders suing in state court would be out of luck, at least on federal-law grounds. Because any contractual

19. The whole sordid affair is amply chronicled in CHARLES FAlRMAN, 6 HISTORY OF THE SUPREME COURT OF THE UNITEd STATES: ReCONSTRUCTION AND REUNION 1864-88 PART ONE 918-1116 (1971); see also RANDALl BRIDWELl \& RALPH U. WhITTEN, THE Constitution AND THE COMMON LAW 716-19 (1977) (criticizing the bond decisions); TONY FREYER, HARMONY AND Dissonance: The Swift and Erie Cases In American Federal,1sm 58-59 (1981) (discussing inunicipal bond cases as an expansion of Swift); HeRBERT HovenKAMP, ENTERPRISE AND AMERICAN LAw, 1836-1937, at 90-91 (1991) (discussing municipal bond decisions as using general law to ensure an interstate market unencnmbered by rules that reflected local prejudice). For the impact of these decisions on the development of substantive due process, see L.A. Powe, Jr., Rehearsal for Substantive Due Process: The Municipal Bond Cases, 53 TEx. L. Rev. 738 (1975).

20. U.S. ConsT. art. I, $\S 10$, cl. 1. See Chicot County v. Sherwood, 148 U.S. 529 (1893) (holding that a state statute requiring hitigants to present bonds to county court was inapphicable to federal litigants, in part to avoid a Contract Clause problem).

21. See Ann Woolhandler, The Common Law Origins of Constitutionally Compelled Remedies, 107 YALE LJ. 77, 89-99 (1997) (discussing the Court's expansive reading of diversity in Contract Clause cases); see also EDWARd A. Purcell, Jr., Litigation AND INEQUality: Federal DiVERSITY JURISDICTION IN INDUSTRIAL AMERICA, 1870-1958, at 62, 87-147 (1992) (discussing the role of diversity as a "protector of investment capital"). At the same time local governments were being held to their obhigations, however, state governments were sonietimes able to evade theirs because of developing notions of state sovereign immunity and the Eleventh Amendnient. See, e.g., Michael G. Collins, The Conspiracy Theory of the Eleventh Amendment, 88 Colum. L. Rev. 212, 218-21, 238-39 (1988) (book review).

22. If, for example, they were not issued for a "public purpose" as required by a state's constitution, the issuance could be declared void and unenforceable. See, e.g., Whiting v. Sheboygan \& Fond du Lac R.R., 25 Wis. 167 (1870) (holding state bond legislation authorizing taxation for a private or limited public purpose in violation of state constitution); see also State ex rel. Burlington \& Mo. River R.R. v. County of Wapello, 13 Iowa 388 (1862) (holding that state legislation authorizing local bond issuance violated state constitution). 
impairment in these settings was due to state judicial rather than legislative action, according to the Court's precedents there was no Contract Clause violation. Thus, there was no direct review in the U.S. Supreme Court. $^{23}$

\section{a. "General Constitutional Law" in the Federal Courts}

When similar cases were brought in the federal courts, however, those courts neither abstained froin hearing them nor attempted to decide thein as would their state court counterparts. Even in cases that presented no federal issues at all, federal diversity courts often upheld the validity of municipal bonds based on principles of "general law" that frequently differed froin state law. On the one hand, because municipal bond litigation involved creditors' rights, it 1might appear to fit neatly within traditional conceptions of the general common law governing the enforcement of contracts, characterized by the landmark decision in Swift v. Tyson. ${ }^{24}$ There, the Supreme Court sanctioned federal courts' refusal to conform their decisions to state substantive law in matters of so-called "general" (as opposed to "local") jurisprudence. On the other hand, issues surrounding the powers of local governmental bodies subject to state statutory and state constitutional provisions might seem to be unlikely candidates for the application of general law. Even though, under Swift, general law could trump state common law in the federal courts, ${ }^{25}$ the powers of state and local governmental bodies would appear to involve matters of local law over which states and state courts would have the last word.

Nevertheless, federal courts applied general law principles even in respect to certain powers of subordinate governmental bodies under state law. ${ }^{26}$ ln a series of notorious decisions associated with

23. See, e.g., Railroad Co. v. McClure, 77 U.S. (10 Wall.) 511 (1871); see also Tidal Oil v. Flanagan, 263 U.S. 444, $451 \&$ n.1 (1924) (recounting nineteenth century precedent).

24. 41 U.S. (16 Pet.) 1 (1842), overruled by Erie R.R. v. Tompkins, 304 U.S. 64 (1938).

25. See generally William A. Fletcher, The General Common Law and Section 34 of the Judiciary Act of 1789: The Example of Marine Insurance, 97 HARV. L. ReV. 1513, 1516-18 (1984) (viewing Swift as concerned with "local" versus "general" matters rather than "statutory" versus “common-law"). General law could occasionally even trump state statutes, see Watson v. Tarpley, 59 U.S. (18 How.) 517, 521 (1855), and state court judicial interpretations of them, despite the default rule that state judicial glosses on state statutes were considered to be part of the statute, see Leffingwell v. Warren, 67 U.S. (2 Black) 599, 603 (1863).

26. See, e.g., Loan Ass'n v. Topeka, 87 U.S. (20 Wall.) 655, 663 (1875); Olcott v. Supervisors, 83 U.S. (16 Wall.) 678, 690 (1872); Pumpelley v. Green Bay Co., 80 U.S. (13 Wall.) 166, 177-79 (1871). As one lower federal court stated, a subject sucli as a legislature's general power to tax and to delegate sucli power was a question of general rather than local law, because it involved mattcrs that "might arise as well in one state as another." Northern Pac. R.R. v. Roberts, 42 F. 734, 737 (C.C.W.D. Wis. 1890). But cf. City of Detroit v. Osborne, 135 U.S. 492, $497-99$ (1890) (treating the question of the duty of a municipality under state law to keep a sidewalk in repair as a question of local law, not general law, imdicating that "[i]t is undoubtedly a question of local policy with each state what shall be the extent and character of the powers which its various political and municipal 
Gelpcke v. City of Dubuque, ${ }^{27}$ federal diversity courts often ignored state court decisions limiting the powers of municipalities to provide financial assistance to railroads and other fledgling enterprises. If state decisional law at the time of the bonds' issuance favored their validity as a matter of state law, then federal courts would commonly ignore subsequent, contrary interpretations of state law that might frustrate imvestor expectations. ${ }^{28}$ Although these decisions reflected Contract-Clause-like concerns, they were not grounded in federal law. ${ }^{29}$

Even when there had been no state court decisions upholding municipal powers when bonds were issued, federal courts still ignored postissuance state court decisions purporting to deny municipalities the ability to provide financial assistance in the first place. ${ }^{30}$ In domg so, federal courts applied their own presumptions about the scope of state and local governmental powers, and they interpreted state constitutional provisions based on what they referred to as principles of "general constitutional law."31 In such cases, especially when investor expectations happened to be at issue, a state court's construction of its own constitution and laws might be helpful, but not controlling. As a consequence, state court rulings with respect to the scope of local governmental powers had only prospective effect in the federal courts; they could not control bond issuances that preceded such rulings. ${ }^{32}$ For example, the

organizations shall possess" (quoting Claiborne Co. v. Brooks, 111 U.S. 400, 410 (1884)); BRIDWELL \& WHITTEN, supra note 19, at 16-19 (arguing that municipal bond cases should have been decided on the basis of local law).

27. 68 U.S. (1 Wall.) 175 (1863) (enforcing, in a diversity action, municipal bonds despite intervening state supreme court decision denying their validity.)

28. See id. at 206. Instead, the law as it was understood at the time of the bonds' issuance would be enforced.

29. See Bacon v. Texas, 163 U.S. 207, 221 (1896) ("[W]e have no jurisdiction, because a state court changes its views in regard to the proper construction of its state statute, although the effect of the judgment may be to impair the value of what the state court had before that held to be a valid contract."); see also Railroad Co. v. McClure, 77 U.S. (10 Wall.) 511, 515 (1871) (judicial interpretation of state law does not amount to a violation of the Contract Clause even if the interpretation has retroactive impact); Railroad Co. v. Rock, 71 U.S. (4 Wall.) 177 (1867) (same). Chief Justice Taft later said of the Gelpcke line of cases that "[t]hey did not base th[eir] conclusion[s] on Article I, $\S 10$, of the Federal Constitution, but on state law as they determined it." Tidal Oil v. Flanagan, 263 U.S. 444, 452 (1924); see also G. EDWARD WhITE, 3 \& 4 HistoRY OF THE Supreme Court of the United States: The Marshall Court and Cultural Change, 1815-35, at 611 (1988) (noting that the Court could invoke general law as well as federal constitutional principles in diversity Contract Clause cases, but only federal constitutional principles on direct review from state courts in such cases).

30. For these variations on Gelpcke's theme, see Barton H. Thoinpson, Jr., The History of the Judicial Impairment "Doctrine" and Its Lessons for the Contract Clause, 44 STAN. L. REv. 1373, 1405 (1992); see also Suzanna Sherry, The Eleventh Amendment and Stare Decisis: Overruling Hans v. Louisiana, 57 U. CHI. L. REv. 1260, 1265-69 (1990) (noting the expansiveness of the Court's general constitutional law decision inaking).

31. Davidson v. New Orleans, 96 U.S. 97, 105 (1877).

32. The rulings would have prospeetive effect in the sense that they would only apply to primary behavior that occurred after the rulings and, therefore, with notice. See, e.g., Rowan v. 
Supreme Court once invoked what it considered to be a principle of "general jurisprudence" that local governmental assistance for the building of a railroad involved expenditures for a "public purpose," and was therefore allowable under the relevant state constitution. ${ }^{33}$ That fmancial assistance to such an end was arguably not permitted under the state constitution proved no cause for hesitation. Indeed, the Court reached its result even though the state courts had given an opposite readimg to the state constitution's public-purpose limitation on governmental expenditures. Because the state court decisions came after expenditures had been undertaken, they were ignored. ${ }^{34}$

The Court's general constitutional law presumptions did not exclusively favor creditors, however. In Loan Association v. Topeka, ${ }^{35}$ another diversity action, the Court concluded that local taxation to pay off bonded indebtedness incurred in subsidizing the building of a private manufacturing plant (unlike construction of a railroad) was not taxation for a public use under the state constitution. Although by state-law standards the issue was unclear, the Court seized on the absence of a clear statement from the state constitution as an excuse to apply its own principles, and to reject the claims of the bondholders. The general constitutional default rule that the Court applied in Loan Association was one that it found to be in harmony with prevailing interpretations of similar constitutional provisions in other state constitutions. ${ }^{36}$ The Court was frank about why it felt justified in its somewhat cavalier disregard of the relevant state's law in such cases: "[W] hether a use is public or private is not a question of constitutional construction. It is a question of general law." As such, said the Court, "it has as much reference to the constitution of any other State as it has to the [particular] State."37 Thus, the Court's sense of what constituted a public purpose would provide the

Runnels, 46 U.S. (5 How.) 134, 139 (1847) (ignoring state courts' construction of the state constitution to protect contracts entered into prior to that construction). The cases reflect, in addition to generallaw presumptions about powers of government, a general-law presumption against unfair retroactivity. See Thoinpson, supra note 30, at 1405-12, 1424-26; see also PAUL BREST \& SANFORD Levinson, Processes of Constitutional Decisionmaking 102-10 (3d ed. 1992) (discussing theories of vested rights and natural law that the Court applied in cases on review from federal courts).

33. See Township of Pine Grove v. Talcott, 86 U.S. (19 Wall.) 666, 676-77 (1874).

34. See id. at 677-78.

35. 87 U.S. (20 Wall.) 655 (1874).

36. See id. at 665-67. In construing this ostensibly state-law question, the Court in Loan Association referred to "limitations on [governmentall power which grow out of the essential nature of all free governments," and stated that there could be "no lawful tax which is not laid for a public purpose." Id. at 663-64. Justice Clifford dissented, objecting to the majority's invocation of a "vague ground" and reliance on a "general latent spirit supposed to pervade or underlie the state constitution, where neither the terms nor the implications of the instrument disclose any such restriction." Id. at 669 (Clifford, J., dissenting).

37. Olcott v. Supervisors, 83 U.S. (16 Wall.) 678, 690 (1872). 
rule of decision when federal courts exercising diversity jurisdiction encountered such provisions in state constitutions. ${ }^{38}$

\section{b. Federal Court Rejection of State-Law Limitations on Judicial Review}

Not only did the rules of decision in such federal cases differ from those in state court; federal courts also often ignored state statutes that limited suits on local government bonds to particular local courts of the state. Without any inquiry into the purpose of these statutes, the Supreme Court consistently rejected arguments that the state that created claims for relief could so limit them as to oust federal jurisdiction over them. ${ }^{39}$

State law purporting to restrict particular types of actions for recovering on local governmental indebtedness were similarly held inapplicable in federal court if the restrictions would have barred federal jurisdiction. ${ }^{40}$ For example, state statutes might prescribe as an exclusive remedy $\mathrm{m}$ the event of a bond default the filing of a "Inandamus" action to recover against local officials. ${ }^{41}$ Because federal courts did not

38. The use of general constitutional law may reflect a concern about bias in state law, not just in state tribunals, directed toward out-of-state citizens. By deciding, in effect, what state law "ought" to be, federal courts were able to check such bias. Although, in a post-Erie world, fashioning of nonfederal general-law norms may no longer be a permissible aspect of diversity, legislative bias against out-of-staters is addressable through various federal constitutional provisions including the Interstate Privileges and Immunities Clause (U.S. CoNST. art. IV, $\S 2$, cl. 1), the Equal Protection Clause (U.S. CONST. amend. XIV, § 1), and, in soine contexts, the Dormant Commerce Clause (U.S. CoNsT. art. I, § 8). For the possibility that diversity was, as an originalist matter, aimed not only at providing a neutral forum but also neutral laws, sce Henry J. Friendly, The Historic Basis of Diversity Jurisdiction, 41 HARV. L. REV. 483, 493-97, 501 (1928) (deemphasizing "local prejudice" as a rationale for diversity jurisdiction, but also seeing the desire to protect creditors from pro-debtor legislation as another significant motivation); Wythe Holt, "To Establish Justice": Politics, the Judiciary Act of 1789, and the Invention of the Federal Courts, 1989 DuKE L.J. 1421, 1455-58 (focusing on the pro-debtor legislation of some states); Hessel E. Yntema \& George H. Jafin, Preliminary Analysis of Concurrent Jurisdiction, 79 U. PA. L. REv. 869, 873-78 \& n.13 (1931) (noting that state debtor-relief laws were a manifestation of local prejudice at which diversity jurisdiction was aimed).

39. See Cowles v. Mercer County, 74 U.S. (7 Wall.) 118, 118-21 (1868) (rejecting the argunient that there was no federal jurisdiction due to a state supreme court decision that counties could not be sued at common law independent of a legislative provision which only allowed suit in the state circuit court of the county); $c f$. Games v. Fuentes, 92 U.S. 10, 17 (1875) (holding that the state court erred in denying removal based on its characterization of the action as one to annul a will, and re-characterizing the action as one between parties contesting the land title of a legatee); Railway Co. v. Whitton's Adm'r, 80 U.S. (13 Wall.) 270 (1871) (holding that the state could not limit a wrongful death action to its own courts).

40. See, e.g., Davenport v. County of Dodge, 105 U.S. 237, 242 (1881); cf. Gaines, 92 U.S. at 19 (stating that it did not matter for purposes of removal that the action was brought in a state court of limited jurisdiction); Kohl v. United States, 91 U.S. 367, 369 (1875) (rejecting the argument that the United States, in condemning land where no federal statutory action existed, could only proceed under the authority of state law and in state tribunals).

41. See Davenport, 105 U.S. at 242 (discussing state statutory provisions for mandamus); see also Woolhandler, supra note 21 , at 110 (discussing the muricipal bond cases). 
have authority to issue such writs, ${ }^{42}$ local government officials plausibly argued that no action to recover on local bonds could be brought in federal courts. The Supreme Court, however, allowed out-of-state creditors suing in federal court to bring suits other than mandamus actions to accommodate their claims to the strictures of federal jurisdiction. ${ }^{43}$ It did so not by concluding that such cases arose under federal law, but as a means of upholding the federal diversity courts' authority to enforce what was ostensibly state law. ${ }^{44}$

\section{Local Powers of Eminent Domain}

\section{a. The General Law of Takings}

Developinents parallel to those in the municipal bond context took place in the area of governmental takings and eminent domain. Even before the Court applied the Fifth Amendment's no-takings principle against state and local governments, federal diversity courts limited local governmental bodies' power to take and condemn property. ${ }^{45}$ Although purporting to construe local governinental powers within the meaning of state law, the federal courts followed general constitutional principles as they did in other contexts.

In Pumpelley v. Green Bay Co. ${ }^{46}$ for example, the Court resolved whether a state-authorized dain's flooding of an out-of-state plaintiff's land was a taking that required just compensation under the Wisconsin Constitution. ${ }^{47}$ Despite arguments that no taking had occurred because the plaintiff still possessed his property (and that consequential injuries

42. See McIntire v. Wood, 11 U.S. (7 Cranch) 503 (1813).

43. Despite the inability of the federal courts to entertain an original mandamus action, the federal courts could use mandamus as a post-judgment remedy to force local officials to raise the funds necessary to pay off the debts. See, e.g., Riggs v. Johnson County, 73 U.S. (6 Wall.) 166, 194, 197-98 (1867). The Court, however, did not allow for removal of mandamus actions filed originally in state court. See Rosenbaum v. Bauer, 120 U.S. 450 (1887).

44. See Davenport, 105 U.S. at 242 (allowing suit on contract and rejeeting the argument that mandamus was the only remedy).

45. See Chicago, Burlington \& Quincy R.R. v. Chicago, 166 U.S. 226 (1897) (incorporating a no-takings principle as part of the federal due process limit on states); cf. Madisonville Traction Co. $v$. Saint Bernard Mining Co., 196 U.S. 239, 254 (1905) (stating that direct review in the United States Supreme Court from the state system could not substitute for diversity jurisdiction in a condemnation suit because the question whether the local statute authorized the condemnation, and the question of the amount awarded as compensation, would not ordinarily involve federal rights).

46. 80 U.S. (13 Wall.) 166 (1871).

47. The flooding had bcen undertaken by a private company that the state legislature had authorized to condemn property to build the dam. The company operated like an agency that had been delegated governmental powers by the state to accomplish specific objectives. Indeed, in the pre-bureaucratic era, government often delegated specialized tasks and powers to private entities much as it would delegate such matters to governmental agencies in a later day. See generally Morton J. Horwitz, The Transformation of AMERICAN LAw, 1780-1860, at 64-67 (1977) (discussing public improvements by private companies); cf. Pumpelley, 80 U.S. (13 Wall.) at 175 (noting defendant's plea that it had not exceeded its statutory authority). 
arising from governmental improvement projects should go uncompensated), the Court found a compensable taking. ${ }^{48}$

Although the decision purported to rest on the Wisconsin Constitution, state law and state court decisions played only a minor role in the Supreme Court's analysis. Instead, the Court relied mainly on constitutional provisions of other states that were similar in wording to Wisconsin's, and on opimons from other state courts that had construed the meaning of the "universal" no-takings principle which takings clauses in general were thought to embody. ${ }^{50}$ The Supreme Court's refusal to construe the state constitution as allowing the particular injury to property to go uncompensated stemmed from its self-declared interpretative baseline that a constitutional norm designed for the protection of cominon-law rights should not be construed in a manner that would be hostile to them. ${ }^{\text {sI }}$

\section{b. Valuation Commissions}

Early treatment of state-created valuation commissions reinforces the portrait of a federal judiciary unwilling to be hamstrung by statecreated forms of actions in the judicial review of agency decision making. In the nineteenth century, specially appointed commissions ${ }^{52}$ or " juries" ${ }^{53}$ were used to inake initial valuations of property for eminent domam or other governmentally authorized takings. Although these ad hoc decision making bodies were hardly agencies im the modern sense, they exercised a slice of state power and performed agency-like functions in a pre-bureaucratic era. A party dissatisfied with the initial determination of such a body inight thereafter have the opportunity to " appeal" ${ }^{54}$ its determination to a state court. The state court on appeal

48. See Pumpelley, 80 U.S. (13 Wall.) at 177-78.

49. Id. at $178-79$.

50. As the Court stated: "[T]he court rests its decision upon the general weight of authority and not upon anything special in the language of the Wisconsin bill of rights..." Id. at 180 .

51. See id. To be sure, in Pumpelley, there were no state court interpretations that flatly ran against the Court's interpretation of the state constitution, although some opinions arguably pointed in a different direction. See id. But in other decisions, the Court felt free to ignore a state court's interpretation of a state constitution's takings clause if these "uriversal" principles would otherwise be undermined. See Yates v. Milwaukee, 77 U.S. (10 Wall.) 497, 502-03 (1870) (noting argument of counsel).

52. See, e.g., Boom Co. v. Patterson, 98 U.S. 403, 404 (1878) (describing state procedure); see also Searl v. School Dist. No. 2, 124 U.S. 197, 198-99 (1888) (describing a state practice that provided for the appointment of a commission; alternatively, the defendant in the condemnation proceeding could demand that the case be tried before a jury of six freeholders, in the same manner as other cases).

53. See, e.g., Pacific R.R. Removal Cases, 115 U.S. 1, 5 (1885) (describing state process of summoning a jury before a mayor to determine the value of the land taken and the enhancement of value to the extent the property was improved by street widening).

54. See Boom Co., 98 U.S. at 404 (describing state procedures for approval). 
characteristically undertook a de novo reexamination, particularly on the crucial issue of valuation. ${ }^{55}$

But out-of-state parties who were dissatisfied with the commission's or jury's findings had another option: to file an original action in federal court, or to remove the state court action at the appeal phase. Those resisting federal jurisdiction on removal argued that because the judicial proceedings had already begun at the commission level, the attempt to remove came too late. ${ }^{56}$ Similarly, parties seeking to avoid a federal proceeding contended that the federal suit was in the nature of an appeal (from a judicial proceeding before the commission) which federal trial courts could not entertain. ${ }^{57}$ While such arguments stressed the judicial nature of the initial commission determination, sometimes the argument 1night be just the opposite - to the effect that the state court proceedings on review of the commission or jury were not sufficiently judicial to be brought in a federal court, either by removal or through an original action. . $^{5}$

Despite the plausibility of such arguments, the Supreme Court regularly allowed for federal trial court jurisdiction once a dispute had reached the point of an appeal from the commission to the state courts. ${ }^{59}$ For example, in Madisonville Traction Co. v. Saint Bernard Mining

55. See, e.g., Pacific R.R. Removal Cases, 115 U.S. at 6; see also Commissioners of Rd. Improvement Dist. No. 2 v. St. Louis Southwestern Ry., 257 U.S. 547, 553 (1922) (stating that issues of damages and enhanced value of real estate were tried de novo in the state circuit courts).

56. See, e.g., Delaware County Comm'rs v. Diebold Safe \& Lock Co., 133 U.S. 473, 486-87 (1890) (rejecting the argument that removal-occurring after the commission proceedings disallowed payment on alleged contract-was too late); Pacific R.R. Removal Cases, 115 U.S. at 19 (rejecting the argument that removal was too late since proceedings had begun when the mayor summoned the jury to determine value); $c f$. Barrow v. Hunton, 99 U.S. 80, 83-84 (1878) (holding that a removed action to set aside a prior default judgment was more an original equity action than a continuation of the prior suit, over which the federal court would have lacked jurisdiction, although noting that the distinction was "nice"); $i d$. at 84 (holding that the state court decision requiring the action to have been brought in the court that entered the default judgment was not controlling on the federal court).

57. See Pacific R.R. Removal Cases, 115 U.S. at 23 (allowing the railroad to remove an "appeal" to federal court where values for street widening had first been determined by a "jury" of five summoned by the mayor); Hess v. Reynolds, 113 U.S. 73, 80 (1885) (holding that removal for prejudice was timely despite occurring after a commission determination, where it was before a hearing in state court on "appeal").

58. See Madisonville Traction Co. v. Saint Bernard Mining Co., 196 U.S. 239, 251 (1905) (rejecting arguments that the proceedings before a county court where exceptions could be taken froin a commission determination were insufficiently judicial to allow for removal); $c f$. Searl $v$. School Dist. No. 2, 124 U.S. 197, 199 (1888) (stating that the fact that the state provided the alternatives of a commission or court proceeding did not inake the case any less a suit that the federal courts could entertain on relnoval). In Mason City \& Fort Dodge R.R v. Boynton, 204 U.S. 570, 578 (1907), the argument against removal was that the removing landowner should be characterized as a plaintiff, who would not be able to remove under the 1887 revisions to removal. The Court treated the landowner as the defendant in that case. See id. at 580 .

59. See, e.g., Upshur County v. Rich, 135 U.S. 467, 476 (1890) (noting the general rule as to condemned land that the initial proceeding of appraisement is administrative, but if an appeal is taken to a court and litigation is instituted between parties, the proceeding becomes a suit). 
Co., ${ }^{60}$ the Court distinguished between what it called an "administrative" phase and a "judicial" phase-the latter beginning when the proceedings moved to or were eligible to be moved to the regular court system. ${ }^{61}$ It was not merely formalist notions regarding separation of powers that proinpted the distinction between administrative and judicial stages in such proceedings; the Court acknowledged elsewhere that both state courts and state commissions might perform much the same task in determining the value of property..$^{62}$ Rather, the Court looked to the different institutional settings of the respective determinations. ${ }^{63}$ It also explicitly desired to preserve what it saw as a "constitutional right" to a federal forum in the face of variations in state governmental schemes. The fact that state law typically provided that the appeal from commission findings would be reviewed in the regular courts de novo, with the appeal thus resembling an original action, eased the determination that a federal foruin was available. ${ }^{65}$

An additional reason federal courts did not let the availability of state commissions interfere with recogmzing a distinctly judicial phase following admimistrative action was the general law presumption that a judicial phase might be necessary for certain types of proceedings. At

60. 196 U.S. 239 (1905).

61. See id. at 250-51 (recognizing the judicial phase in eminent domain proceeding subsequent to determination by commissioners, even though the review proceeding was mitiated in a county court that had some admimistrative duties); see also Commissioners of Rd. Improvement Dist. No. 2 v. Saint Louis Southwestem Ry., 257 U.S. 547, 554 (1922) (stating that an administrative proceeding transferred to a court usually becomes judicial); Boom Co. v. Patterson, 98 U.S. 403, 406 (1878) (distinguishing the proeeedings before commissioners from the phase when the case was transferred to the court by appeal, at which stage the proceeding, under a state statute, took the form of a suit at law); cf. Pacific R.R. Removal Cases, 115 U.S. at 18-19 (characterizing preliminary proceedings in which a jury was summoned before the mayor as like an inquest of valuations and assessments, not having the character of a suit, which allowed for removal at the "appeal" stage); Hess, 113 U.S. at 79-80 (allowing for removal of a debt claim against an estate that had first been referred to commissioners by a probate judge under local prejudice removal statute that allowed removal at any time before trial or final hearing); $i d$. at 80 (rejecting the argument that the trial had taken place before the commissioners).

62. See, e.g., Delaware County Bd. of Comm'rs v. Diebold Safe \& Lock Co., 133 U.S. 473, 486-87 (1890) (noting that proceedings before commissions as to allowance of payments to a party seeking payment on an alleged contract with the county were in some respects similar to court proceedings).

63. See Hess, 113 U.S. at 80 (rejecting the argument that a proceeding before a commission that had disallowed a debt as against an estate was a trial that precluded later removal under a statute that allowed removal before trial); cf. St. Louis Southwestern Ry., 257 U.S. at 554 (stating that while proceedings for the making of road improvements were in the main legislative and administrative functions, court assessments of benefits were normally judicial).

64. See infra text accompanying notes 104-112.

65. See, e.g., United States v. Jones, 109 U.S. 513, 517 (1883) (describing Wisconsin provisions for initial appraisal by cominissioners, after which either party could "appeal" and have compensation fixed by a jury); cf. Diebold Safe \& Lock Co., 133 U.S. at $474 \mathrm{n} .1$ (noting that an appeal froin the decision of the cominissioners disallowing a contract payment could be taken to the county circuit court, to be tried as an original cause). 
times, for example, the Supreme Court seemed influenced by a general (although not necessarily universal ${ }^{66}$ ) notion that eminent domain decisions required a formal judicial determination of value. ${ }^{67}$ The federal courts' ability to provide their own forms of action thus reinforced their ability to act on background presumptions regarding the availability of judicial process in such cases.

Similarly, if what looked like an agency proceeding involved competing claims of private rights, as might happen when eminent domain powers had been delegated to a private actor, traditional judicial proceedings were especially called for. ${ }^{68}$ In such cases, the long-standing presumption that matters of private right required judicial process ${ }^{69}$ complemented the federal courts' inclination to provide an action without regard to the strictures of state law. Even if the courts were vague as to the contours of private rights, there was indisputably a stronger presumption than today that due process meant judicial process when a potential wealth transfer between private parties was at issue..$^{70}$ Thus, if a state had delegated eminent domain powers to a private company to aid in the construction of public or private works, the presence of valuation

66. See Kohl v. United States, 91 U.S. 367,378 (1875) (Field, J., dissenting) (stating that eminent domain suit nerely required that the proceeding be conducted in some fair and just mode, with or without jury, and with the opportunity afforded to parties to present evidence of value); see also St. Louis Southwestern Ry., 257 U.S. at 555 (stating that while due process did not necessarily require judieial machinery to fix values in condemnation, because of the direct invasion of private right, courts would treat condemnation matters as common-law suits whenever they were brought before theni); Jones, 109 U.S. at 519 (rejccting the federal government's argument that the state courts lacked jurisdiction to entertain a condemnation proceeding involving the federal government, and stating that a proceeding to ascertain the value of property merely involved the ascertainment of fact, and could be prosecuted before commissions, special boards, or a court with or without a jury).

67. See Madisonville Traction Co. v. St. Bernard Mining Co., 196 U.S. 239, 252-53 (1905); Monongahela Navigation Co. v. United States, 148 U.S. 312, 327-28, 345 (1893) (holding that the issue of the measure of compensation for expropriation of a lock franchise was a judicial, not a legislative, determination, so that it was appropriate to ignore Congress's direction not to consider the value of the company's franchise to collect taxes); cf. Kohl, 91 U.S. at 375-76 (allowing a nonstatutory action for condemnation by the United States, and stating that an action to take land for public uses by condemnation is a "suit" at common law); Note, The Mystery of Rule 71A(k): The Elusive Right to Federal Diversity Jurisdiction over Condemnation Actions Authorized by State Statute, 64 YALE L.J. 600, 601 (1955) (stating that although judicial review of the nccessity of condemnation might be precluded, the issue of compensation was always judicial).

68. See, e.g., Madisonville Traction Co., 196 U.S. at 252-53 (stating that the state cannot exclude federal jurisdiction when a condemnation proceeding was esscntially a controversy between citizens of different states); $c f$. Janes William Moore \& William VanDercreek, Federal Removal Jurisdiction-Civil Action Brought in a State Court, 14 Sw. LJ. 297, 310-13 (1960) (indicating that a civil action for removal purposes would exist where a judicial appeal inter partes followcd an administrative determination).

69. See Murray's Lessee v. Hoboken Land \& Improvement Co., 59 U.S. (18 How.) 272, 284 (1855) (indicating that Congress could not withdraw from judicial cognizance "any matter which, fron its nature, is the subject of a suit at common law, or in equity, or admiralty").

70. See, e.g., Upshur County v. Rich, 135 U.S. 467, 476 (1890) (deducing the principle that an appeal from an assessment, while ordinarily administrative, could become a suit if, inter alia, there were litigants to contest the case on both sides). 
questions as well as private-rights questions combined to support a finding that there was a distinctly judicial phase at which federal jurisdiction was appropriate as between diverse parties. ${ }^{71}$

It might follow from this notion of private rights that disputes between citizen and government could more easily escape regular judicial process than disputes between private parties. But the federal courts seeined to treat many matters that arose between citizen and government as involving private rather than public rights, especially when the citizen sought to recover for a trespassory injury to property or person inflicted by a government official. ${ }^{72}$ The sense that government arguably had to supply judicial remedies for officer trespasses buttressed the federal courts' willingness to supply their own actions, despite state-law restrictions on them. ${ }^{73}$ This is not to say that judicial process was required for all governmental exactions. ${ }^{74}$ The presumption favoring judicial process for valuation questions in the eminent domain context, contrasted, for instance, with valuation questions in the tax assessment context. There, for reasons that are less than clear, the Court upheld state provisions that foreclosed review in the regular courts. ${ }^{75}$ But even in those areas in

71. See supra text accompanying notes 59-66; see also, e.g., Commissioners of Rd. Improvement Dist. No. 2 v. Saint Louis Southwestern Ry., 257 U.S. 547, 555 (1922) (stating that, because of the direct invasion of private rights in determining the value of condemned land, courts should treat such proceedings as potentially removable civil actions whenever they were brought before a court, even if due process did not require a judicial determination of value). The idea that direct government orders transferring wealth between private parties required judicial process would later support arguments in favor of federal judicial process in review of worker compensation actions, whether the initial agency decision happened to be state or federal. See, e.g., Horton v. Liberty Mut. Ins. Co., 367 U.S. 348, 355 (1961) (rejecting the argument that an appeal from a workers' coinpensation board determination was appellate and could not be entertained by the fcderal district court); Crowell v. Benson, 285 U.S. 22, 51 (1932) (characterizing a worker compensation proceeding as a matter of private right from which judicial involvement could not be completely excluded); cf. 28 U.S.C. $\$ 1445$ (c) (1994) (prohibiting the removal of a "civil action" arising under worker compensation laws of the state in which the action was brought).

72. See, e.g., Poindexter v. Greenhow, 114 U.S. 270, 302-03 (1884) (indicating, in the context of a suit against a government offieer, that a state could not abolish ordinary trespass actions); Umited States v. Lee, 106 U.S. 196 (1882) (entertaining a trespass action against federal officials in custody of land); cf. Marbury v. Madison, 5 U.S. (1 Cranch) 137 (1803) (discussing in terms of vested private rights a suit for mandainus directed against the Secretary of State to obtain a judicial commission).

73. See Woolhandler, supra note 21, at 120-21 (suggesting that the Court saw the existence of some common-law actions against individual officers as constitutionally compelled).

74. See, e.g., Rich, 135 U.S. at 472 (holding that appeals from tax assessments to special tribunals, sometimes called boards of commissioners of appeal, were not usually suits and could not be removed); id. at 473,474 (stating that original assessments were clearly not suits, but were administrative); cf. St. Louis Southwestern. Ry., 257 U.S. at 559-60 (distinguishing tax assessment cases such as Rich from a proceeding to assess danages and benefits from improvements).

75. See supra note 74. Tax assessments had requirements of due process in the sense of notice and opportunity to be heard, but judicial process was not necessarily a requirement of due process as it was in other contexts. See, e.g., Turner v. Wade, 254 U.S. 64, 70 (1920) (holding, on direct review from state court, that a state scheme, as interpreted by the state supreme court, was defective in not affording notice and opportunity to be heard before an increased assessment becane final); see also Londoner v. City and County of Denver, 210 U.S. 373, 385-86 (1908) (stating that due process 
which judicial process was not ordinarily required, if a state gratuitously provided for genuine judicial process but also purported to make state courts the exclusive judicial forum in which to proceed, a federal diversity forum was still available. ${ }^{76}$

\section{B. Federal Judicial Review of Early State Rate-Setting Agencies}

Federal courts encountered regulatory agencies of the modern type when, following the Civil War and Reconstruction, states began to create rate-setting bodies to regulate railroads and other businesses. The federal courts' treatment of such agencies resembled their freewheeling treatnient of municipal powers in the areas of public finance and eminent domain. Most importantly, general-law default rules and presumptions controlled federal courts' resolution of ostensibly state-law questions such as the scope of an agency's authority to set rates, and the reasonableness of rates. In addition, and again as in the municipal bond decisions, state-imposed forms of action did not limit federal court jurisdiction.

\section{Policing Delegation of Rate-Setting Authority}

Although parties only occasionally litigated the scope of state agency authority in the federal courts, the results in such cases were significant. As a matter of general constitutional principles, state

required notice and opportunity to be heard before a tax became irrevocably fixed, particularly under a scheme where there was no judicial review of the assessment); Ann Woolhandler, Judicial Deference to Administrative Action-A Revisionist History, 43 ADMIN. L. REV. 197, 221-23 (1991) (discussing the Court's approval of lack of judicial review for valuation issues in connection with decisions involving customs collections). In addition, systemic challenges to taxes and assessment procedures - for example, a claim that plaintiff's property was assessed based on full value while all others were assessed at $50 \%$-would be considered suits that federal equity courts would entertain, even in the teeth of state statutory limitations. See Greene v. Louisville \& Interurban R.R., 244 U.S. $499,512-13$ (1917) (sustaining an injunction on state-law grounds despite a state supreme court holding that unequal assessnients were only administratively, not judicially, remediable).

76. See, e.g., Rich, 135 U.S. at 474 (stating that while tax assessments and appeals therefrom were not ordinarily suits, the legality and constitutionality of taxes and assessments might be challenged by way of a suit which might come within the cognizance of federal courts); see also Madisonville Traction Co. v. Saint Bernard Mining Co., 196 U.S. 239, 249 (1905) (noting that state proceedings considering the issue of the necessity of the condemnation rather than just the amount of compensation did not prevent the proceeding from being judicial); Smith v. Adams, 130 U.S. 167, 173 (1889) (finding no jurisdiction over appeal on other grounds, yet stating that designation of county seat, while nornally a legislative matter, could become a matter of judicial cognizance when the law of the territory provided for election contests); Ames v. Kansas ex rel. Johnston, 111 U.S. 449, 459-60 (1884) (holding that state quo warranto suit to forfeit railroad franchises was in the nature of a civil proceeding under Kansas statutes, and was therefore removable). But cf. Madisonville Traction, 196 U.S. at 257-60 (Holmes, J., dissenting) (arguing that a proceeding to determine the propriety of taking land was a prerogative of the state that the fcderal courts shonld not entcrtain, although the issue of compensation can be a controversy); Murray's Lessee v. Hoboken Land \& Improvement Co., 59 U.S. (18 How.) 272, 284 (1855) (referring to matters that are capable of judicial rcsolution but that do not necessarily rcquire it). 
agencies had to conform their exercise of delegated powers to statutory limits and procedures; federal courts with jurisdiction would review such compliance. ${ }^{77}$ For example, in deciding a pendent state-law claim in Siler v. Louisville \& Nashville Railroad Co. ${ }^{78}$ the Court held that it would not presume that a state agency had been delegated power to set rates absent an explicit state statute to that effect. ${ }^{79}$ The source of law here was neither state law nor the federal Constitution. Rather, the Court seemed to rely on general constitutional principles of nondelegation, not unlike those it invoked in its conternporaneous discussions of the powers of the earliest federal agencies. ${ }^{80}$ In the state, as well as the federal arena, only the clearest of legislative expressions in favor of delegation could overcome the Court's government-limiting, general-law default rule to the contrary. ${ }^{81}$ That state courts had not construed the applicable state law in Siler proved no cause for hesitation on the part of the federal courts in deciding that the requisite clear statement was missing. ${ }^{82}$

\section{Policing Rate Reasonableness}

The reasonableness of particular rates set by state agencies was more frequently litigated in the federal courts than was the power to set rates themselves. As in eminent domain proceedings, "reasonableness" during this period depended on a valuation of the regulated entity's property. States themselves might provide for state court judicial review of the reasonableness of agency-set rates; indeed, the Supreme Court eventually held that they were obliged to do so as a nnatter of procedural

77. See Wichita R.R. \& Light Co. v. Public Utils. Comm'n, 260 U.S. 48, 58-59 (1922) (stating that compliance with statutory limitations was necessary to prevent "pure delegation"); see also Mahler v. Eby, 264 U.S. 32, 44 (1924) (reading Wichita Railroad \& Light Co. to support a holding that a federal officer must comply with statutory requirements of a specific finding for a valid warrant).

78. 213 U.S. 175 (1909).

79. See id. at 193-94; $c f$. Detroit \& Mackinac Ry. v. Michigan R.R. Comm'n, 235 U.S. 402, 40406 (1914) (interpreting a state statute as not allowing the state court to enter a new rate, to avoid conflict with strict separation of powers under the state constitution). But cf. Home Tel. \& Tel. Co. v. City of Los Angeles, 227 U.S. 278, 282-83 (1913) (holding that a possibly unclear question of state law relating to the powers of a city to set rates as a matter of state law did not prevent the conclusion that the city-set rates constituted "state action" under the Due Process Clause).

80. See ICC v. Cincinnati, New Orleans \& Tex. Pac. Ry., 167 U.S. 479, 494-95 (1897) (interpreting the 1887 congressional enactment creating the Interstate Commerce Commission as not granting the Commission power to prescribe rates for the future).

81. See Siler v. Louisville \& Nashville R.R., 213 U.S. 175, 193-94; see also Cincinnati, New Orleans \& Tex. Pac. Ry., 167 U.S. at 494-95 (stating that power to sct rates would never be implied); cf. Dreyer v. Illinois, 187 U.S. 71, 83 (I902) (holding that a Iocal statute conferring judicial power on persons not in the judicial department did not present a federal question for direct review); Parks v. Board of Comm'rs, 6I F. 436, 439 (C.C.D. Kan. 1894) (relying largely on general constitutional principles to hold that a state statute delegating authority to tax to private parties violated the state constitution).

82. See Rehnquist, supra note 2, at 1070-71 \& n.120 (noting that state courts had not construed the statute at issue in Siler). 
due process. $^{83}$ But even though the Federal Constitution required the availability of state court review of rate-reasonableness, the substance of rate-reasonableness was initially not treated as a question of federal law. Instead, in diversity cases, federal courts dealt with the question of reasonableness based on general-law principles.

A nice illustration of this approach was Reagan v. Farmers' Loan $\&$ Trust Co. ${ }^{84}$ a diversity case in which an out-of-state plaintiff sued the state officials responsible for setting and enforcing rates governing railroads. In resolving the issue of reasonableness, the Court did not indicate that it was dealing with a federal question, and it reviewed the issue much as a state court would have been required to had the case been brought in state court. But because federal courts assessed reasonableness based on general-law notions of proper valuation, their results would not necessarily mirror those in state courts. More significantly, the Court in Reagan held that states could not restrict judicial consideration of rate-reasonableness to their own courts by requiring that suits be brought only against the rate-setting agency itself and only in the state courts of a particular county. Instead, said the Court, if diversity existed between the complaining party ${ }^{85}$ and relevant state officials, then the challenge could be brought in federal court regardless of state limits. $^{86}$

It was only later, in Smyth $v$. Ames, ${ }^{87}$ that the Court decided whether rate-reasonableness presented a federal question. ${ }^{88}$ In concluding that it did, the Court declared that an inadequate rate of return would require a party to use property for the public benefit without just compensation and result in a violation of the Fourteenth Amendment's Due Process Clause. ${ }^{89}$ Analogizing to determinations of value in the eminent domain context, the Court found that a taking of property would occur absent a "fair return" on the current value of the property employed for the public convenience. ${ }^{90}$ Federal courts thus began to assume federal question jurisdiction over the same sorts of cases that they had already been hearing in the exercise of their diversity jurisdiction..$^{91}$ The actual

83. See Chicago, Milwaukee \& St. Paul Ry. v. Minnesota, 134 U.S. 418, 458 (1890).

84. 154 U.S. 362 (1894).

85. The Court made it easier for regulated parties to obtain diversity by allowing suits challenging state laws and regulations by shareholders and bondholders. See Woolhandler, supra note 21 , at 95-99.

86. See Reagan, 154 U.S. at 391.

87. 169 U.S. 466 (1898).

88. See id. at $518,545-47$.

89. See id. at $525,545-47$.

90. See id. at 546-47. The Court's implication that "fair" value meant the current value of the enterprise persisted, moreover, until well into the New Deal. See Stephen A. Siegel, Understanding the Lochner Era: Lessons from the Controversy over Railroad and Utility Rate Regulation, 70 VA. L. REv. 187, 259 \& n.307 (1984).

91. See, e.g., Ex parte Young, 209 U.S. 123, 145 (1908). 
substantive content of reasonableness as a matter of federal due process, however, did not differ materially from the content of reasonableness as a matter of general law in diversity. Instead, there was an almost seamless transition from a general-law rule to protect investment property (developed in diversity cases) to a genumely constitutional rule (developed in federal question cases). Thus, whether the case presented a general-law issue for diversity jurisdiction, or, later, a federal question, state court attempts to limit review of agency-set rates to particular state forums were unavailing. ${ }^{92}$ And, of course, sovereign immunity usually would not be an obstacle when the state's officer rather than the agency was sued for injunctive relief-a conclusion famously reaffirmed by the Court in Ex parte Young. ${ }^{93}$

\section{Local Governments and Early State Agencies: The Parallels}

In a number of ways, the rate cases reiterate the relationship of federal courts to state constitutional law that was exhibited in the municipal power and takings contexts. These similarities tend to support the suggestion that state agency and state municipal powers issues were two sides of the same coin.

\section{Lack of Uniform Outcomes}

First of all, the rate cases, the mumicipal bond cases, and the eminent domam cases show an indifference to whether the result in federal court reflected the result that would be reached in state court, even as to legal issues that were not yet explicitly federalized. Indeed, the Court once stated that the fact that a case was of local interest only was "entirely immaterial." Given Swift, of course, non-uniformity in

92. See Smyth, 169 U.S. at 474 (citing a state statute providing that "[a]ll such actions shall be brought before the [state] supreme court, in the name of the railroad company or coinpanies bringing the same, and against the State of Nebraska"); see also id. at 516-17 (quoting Reagan to the effect that the state was unable to restrict out-of-staters with in-state property to its own courts).

93. 209 U.S. 123 (1908). Young was yet another rate case in which the officers responsible for enforcing the rates were sued without imphicating sovereign immunity. Unlike either Reagan or Smyth, jurisdiction could only be premised in Young on federal question jurisdiction, so it presented the added wrinkle of being able to satisfy the well-pleaded coinplaint rule. See Louisville \& Nashville R.R. v. Mottley, 211 U.S. 149, 153-54 (1908).

94. Willcox v. Consolidated Gas Co., 212 U.S. 19, 40 (1909) (taking jurisdiction in a rate case but fimding against the regulated party on the merits). In the late $1920 \mathrm{~s}$, the Supreme Court began to waver on whether it would decide important issues of state agency power. Compare Gilchrist v. Interborough Rapid Transit Co., 279 U.S. 159, 208 (1929) (stating that the interpretation of a contract that may have bound the company contractually to a rate that otherwise umght have been confiscatory was primarily for the local courts), with Railroad Comm'n v. Los Angeles Ry. Corp., 280 U.S. 145, 152 (1929) (deciding state issues). See also Felix Frankfurter \& Janies M. Landis, The Business of the Supreme Court at October Term, 1928, 43 HARv. L. Rev. 33, 61-62 (1929); David E. Lilienthal, The Federal Courts and State Regulation of Public Utilities, 43 HARv. L. Rev. 379, 398-99 (1930). In addition, Congress required suits for interlocutory mjunctions against the enforceinent of state rate and tax statutes on constitutional grounds, along with other constitutional challenges to state statutes, to 
outcomes was a common feature of federal diversity jurisdiction during this era, even in non-administrative contexts.

\section{Lack of Deference to Party Structure or Standards of Review}

Second, as in the municipal power cases, the federal courts did not adhere to the particular type of lawsuit that the state had prescribed for seeking judicial review of agency action. For example, federal courts might ignore the party structure prescribed by state law, allowing suits against individual officers rather than immune state entities. In addition, although state judicial review often took the form of an appeal on the record that had been made before the agency, federal equity courts did not feel limited by such restrictions. Instead, federal courts might proceed with a new evidentiary hearing even when a state court could not. ${ }^{95}$ Once the federal proceedings (such as challenges to confiscatory rates) were considered to be grounded in a federal cause of action, their independent course arguably followed from the fact that the underlying action was federal. But even before then, the Court tended to allow for a new record im diversity cases in order to accommodate state court actions to federal equity practice. ${ }^{96}$

In addition, even where de novo review was not constitutionally required, federal diversity courts hearing challenges to state administrative action did not necessarily follow the deferential standards of review that state law prescribed. ${ }^{97}$ Under the equitable reniedial rights doctrine, the

be heard by three-judge federal courts, see Act of June 19, 1910, ch. 309, § 17, 36 Stat. 539, 557 (current version at 28 U.S.C. $\S 2284$ (1994)), and later, with the Tax and Rate Injunction Acts, 28 U.S.C. $\$ \S 1341-1342$ (1994), it forbade most such tax and rate injunctions outright. It passed the three-judge court requirement largely in response to decisions such as Ex parte Young, 209 U.S. 123 (1908), and other attacks on state economic regulation. See RoBERT N. CLINTON ET AL., FEdERAL COURTS-THEORY AND PRACTICE 1226-28 (1996) (discussing the pohtics of thrce-judge court provisions). Even when federal courts became shightly more deferential to state law, they still saw their role as providing applications of law that might differ inarkedly from state law. This was particularly evident when federal courts decided issues under state constitutional provisions for equalization of taxes on property of like value. See generally Woolhandlcr, supra note 21, at 145-46 \& nn.350-57 (discussing tax equalization questions).

95. See Lilienthal, supra note 94 , at $407,412-13,416$ (noting the different records for reviev in state and federal courts); cf. Bacon v. Rutland R.R., 232 U.S. 134, 138 (1914) (upholding federal jurisdiction over a challenge to a state order concerning a railroad passenger station, and declaring that state review only provided an altemative and more expeditious way of doing what might be done by a federal court bill in equity); Washington ex rel. Oregon R.R. \& Navigation Co. v. Fairchild, 224 U.S. 510, 527 (1912) (noting that due process was not violated when judicial review was on the record before the agency); id. at 527, 533 (noting that in federal equity, the hearing is de novo and there is no prohibition against offering all competent evidence to prove the order was unreasonable).

96. See, e.g., Wichita R.R. \& Light Co. v. Public Utils. Comm'n, 260 U.S. 48, 51 (1922) (reversing a federal court in part for failure to allow the customer utility to present evidence to traverse the allegations of fact of the seller utility that had been used by the state commission to justify a rate hike).

97. See, e.g., Chicago Burlington \& Quincy R.R. v. Osbome, 265 U.S. 14, 16-17 (1924) (Holnes, J.) (noting that in a tax equalization case, a federal equity court would not be limited to the 
federal equity action was regularly treated as existing independently of state law to protect property, even as to matters that were not explicitly federal..$^{98}$ Thus, whether sitting in diversity or exercising pendent jurisdiction over nonfederal claims, federal courts felt comfortable ignoring state standards of review of agency action. ${ }^{99}$

\section{Differentiating Administrative and Judicial Process}

More explicitly than in the eminent domain cases, the Court held that a judicial determination of the issue of rate-reasonableness based on the present value of the regulated enterprise was required. ${ }^{100}$ Even apart from rate making, however, the Court seemed to see judicial review as necessary to the validity of many administrative acts affecting property rights and economic expectations. ${ }^{101}$ As a corollary, the normal forms of

record made before the Board of Equalization, and by extension would not be bound by facts found by the board, in contrast to the state court); see also Kenneth F. Burgess, Recent Efforts to Immunize Commission Orders Against Judicial Review, 16 IowA L. REv. 53, 58 (1930) (noting differing nature of review in state and federal courts).

98. See generally Note, The Equitable Remedial Rights Doctrine: Past and Present, 67 HARv. L REv. 836, 836 (1954) (observing that federal courts enforced ostensibly state-created rights "im accord with the remedies determined by a uniform federal equity jurisprudence").

99. See, e.g., Osborne, 265 U.S. at 16-17. In some instances, the federal courts appeared to provide the same level of review as did the state courts. For example, in challenges to particular assessinents, where due process did not necessarily require judicial process, but where federal courts could entertain actions if the state provided for judicial review, the federal courts might provide the same level of review as the state courts. See Fallbrook Irrigation Dist. v. Bradley, 164 U.S. 112, 169 (1896); cf. In re Chicago, M., St. P. \& P.R. Co., 50 F.2d 430, 433 (D. Minn. 1931) (using state standards of review); Maurice H. Merrill, Recent Efforts to Immunize Commission Orders Against Judicial Review: A Reply, 16 IowA L. REv. 62, 70 (1930) (indicating that without the decision in Ohio Valley Water Co. v. Ben Avon Borough, 253 U.S. 287, 289, 291 (1920), fact-findings would be reviewed for whether evidence in the record supported them).

100. See, e.g., Chicago, Milwaukee \& St. Paul Ry. v. Minnesota, 134 U.S. 418 (1890) (holding that state courts were required to provide a judicial assessment of the reasonableness of rates); see also Ben Avon, 253 U.S. at 289, 291 (holding that due process required that the judiciary provide its independent judgment as to both law and facts on the issue of confiscatory rates); Smyth v. Ames, 169 U.S. 466, 546-47 (1898) (prescribing present-value rate-base); Siegel, supra note 90, at 227 (indicating that Smyth's list of valuation factors adopted a reproduction-cost or present-value formulation, as opposed to original costs). There was uncertainty about the extent to which the requirement of de novo review for confiscation issues applied in federal Interstate Commerce Commission (ICC) cases. See John G. Buchanan, The Ohio Valley Water Case and the Valuation of Railroads, 40 HARv. L. REv. 1033, 1057 (1927) (noting that the Court had failed to accord such extensive review to ICC orders, although the cases did not squarely present valuation questions). In 1938, Dean Landis described the issue of providing de novo review to constitutional or jurisdictional fact as "the inost disputed field of judicial review over administrative action today." JAMES $M$. Landis, The Administrative Process 140 (1938); see also Morton J. Horwitz, The TRANSFORMATION OF AMERICAN LAW 1870-1960, at 214 (1992) (discussing the rise and intellectual underpinnings of the administrative state).

101. See supra notes 55 \& 76; see also, e.g., Wìchita R.R. \& Light Co. v. Public Utils. Comm'n, 260 U.S. 48, 58-59 (1922) (concluding, in accordanee with general principles of constitutional government, that commission order was void for failure to make finding required by state statute); $c f$. Thompson v. Consolidated Gas Utils. Corp., 300 U.S. 55, 69 (1937) (discussing review for conformity of commission order to statutory authorization and arbitrariness); Bacon v. Rutland R.R., 232 U.S. 
judicial review within the states, whether or not de novo and whether or not denominated as an appeal under state law, continued to be considered judicial rather than administrative. ${ }^{102}$ And as it had in Madisonville Traction Co., the Court repeatedly rejected arguments that sought to foreclose federal court jurisdiction on the theory that judicial review of administrative decision making was something other than an original judicial action. ${ }^{103}$

\section{Forum Restrictions and Diversity as a "Constitutional Right"}

Nor did federal courts adhere to limits on the proper forum in which litigation could take place. ${ }^{104}$ Ignoring state forum restrictions was a matter of course if one assumed, as did the Court, both that a judicial phase was generally necessary for administrative action to be valid, and that there was a right to a federal forum for cases in which subject matter jurisdiction existed. Thus, a fourth and important common thread linking the municipal bond, eminent domain, and rate cases, is what the Court often referred to as the "constitutional right"105 of a diverse party to bring or remove a case to federal court. That right, suggested the Court, could be defeated neither because the state that created the action had also restricted the forums in which suit could be brought, nor because it had restricted the type of action that could be brought. ${ }^{106}$

134, 138 (1914) (Holmes, J.) (holding that federal jurisdiction was proper on review of state agency order, in that the remedy was "purely judicial: to exonerate the appellant from an order that exceeds the law"); ICC v. Illinois Central R.R., 215 U.S. 452, 470 (1910) (outlining the scope of judicial review of an ICC order-whether the order was within the constitutional and statutorily delegated powers to act and otherwise reasonable-and stating that such determinations were the essence of judicial authority which cannot be curtailed). For certain types of proceedings, not only was judicial review required, but the agencies theinselves were required to provide a sort of judicial-style process. See Southern Ry. v. Virginia, 290 U.S. 190, 195 (1933) (indicating that agency hearing and judicial review were required for the state to require elimination of a grade crossing).

102. See, e.g., Keller v. Potomac Elec. Power Co., 261 U.S. 428, 442 (1923) (stating that normal review of ICC orders, although not involving much review of facts, was nevertheless judicial).

103. But cf. infra text accompanying notes $156-160$ (discussing decisions such as Prentis $v$. Atlantic Coast Line Co., 211 U.S. 210 (1908), which characterized certain state court actions as legislative, but allowed for federal trial court review after completion of such "legislative" processes); see also Bacon v. Rutland R.R., 232 U.S. 134, 137 (1914) (indicating that Prentis itself recognized a distinct judicial phase following adinimistrative action).

104. See, e.g., Reagan v. Farmers' Loan \& Trnst Co., 154 U.S. 362, 391 (1894); see also Smyth v. Ames, 169 U.S. 466, 516-17 (1898).

105. See Barney v. Latham, 103 U.S. 205, 210 (1880) (referring to a diverse party's "constitutional right to invoke the jurisdiction of the Federal court"); see also, e.g., Gibson v. Lyon, 115 U.S. 439, 446 (1885); Cowles v. Mercer County, 74 U.S. (7 Wall.) 118, 122 (1869); cf. Hess v. Reynolds, 113 U.S. 73, 77 (1885) (noting the right to a federal forum given by the Constitution of the United States). See generally Goldsmith \& Walt, supra note 15, at 682-85 (recognizing the Court's reliance on the Constitution and Article III during the Swift era to justify the federal courts' independence in the construction of state law).

106. See Madisonville Traction Co. v. Saint Bernard Mining Co., 196 U.S. 239, 253-54 (1905) (holding that the state-prescribed mode of proceeding in a condemnation case that was essentially a suit between private parties could not exclude federal jurisdiction; otherwise a state, by its tribunals, 
"A State," said the Court, "cannot tie up a citizen of another State, having property rights within its territory invaded by the unauthorized acts of its own officers, to suits for redress in its own courts."107

It is unlikely that the Court's reference to the availability of a diversity court as a constitutional right served as a broader suggestion that diversity jurisdiction was somehow constitutionally compelled or beyond congressional restriction. But the Court clearly did see the opportunity of a diverse litigant to invoke the protection of the federal courts - particularly when claiming an imvasion of property ${ }^{108}$-as constitutionally inspired. Once implenuented by Congress, a diverse litigant's right to a federal forum became one that state law could not nuaterially undo. ${ }^{109}$ The Court itself, noreover, was adamant that the constitutional schenie had made the federal judiciary an equal partner in the administration of state law, at least when disputes involving citizens of different states were at issue. ${ }^{110}$

could deprive citizens of other states of their property by condemnation without giving them the opportumity to protect themselves in a national court from local prejudice and influence); see also Prentis, 211 U.S. at 228 (noting that a state could not force a party as to whom there was federal jurisdiction to try the facts relating to confiscation in the state's own courts); Barrow v. Hunton, 99 U.S. 80, 85 (1878) (stating that a state practice requiring an action to annul a default judgment to be brought in the court in which the judgment was rendered was entitled to "some weight," but that the state legislatures cannot deprive federal courts of jurisdiction and interfere with the right of the citizen to resort to federal court).

107. Reagan, 154 U.S. at 391 . Nor could the desire to have all related claims resolved in a single forum defeat federal jurisdiction. See, e.g., Pacific R.R. Removal Cases, 115 U.S. 1, 17-18, 23 (1885) (holding that federal jurisdiction over a removed proceeding to determine damages and benefits from street widening would proceed even though it might delay state proceedings for pro rata assessments, and might inaterially affect those proceedings); Hess, 113 U.S. at 77 (stating that although it might be convenient for all debts of an estate to be established in the court to which the law of the domicile has confided general administration, neither state law nor convenience could deprive federal courts of jurisdiction over a diverse debt claim agamst the estate).

108. See Reagan, 154 U.S. at 391; see also Dodge v. Woolsey, 59 U.S. (18 How.) 331, 356 (1855) (stating, in a shareholder derivative action challenging an increase in taxation as a Contract Clause violation, that diversity jurisdiction was appropriate when brought by a "citizen of the United States, residing in Connecticut, having a large pecuniary interest in a bank in Ohio").

109. See, e.g., Bacon v. Rutland R.R., 232 U.S. 134, 137 (1914) (allowing an equity action to challenge a commission's order as to a passenger station, and stating that the railroad had a right at the judicial phase to resort at once to federal court); Lincohr County v. Luning, 133 U.S. 529, 531 (1890) (holding that the federal court had jurisdiction even though the statute under which the bonds were issued provided for litigation concerning the bonds in a particular court); see also Rosenbaum v. Bauer, 120 U.S. 450, 460 (1887) (Bradley, J., dissenting) (indicating that, although there was a constitutional duty on Congress's part to establish the diversity jurisdiction, the only remedy agamst its failure to do so was the ballot-box).

110. See Burgess v. Sehgman, 107 U.S. 20, 33 (1882) ("The Federal courts have an independent jurisdiction in the administration of State laws, coordinate with and not subordinate to, that of the State courts, and are bound to exereise their own judgment as to the ineaning and effect of those laws."); see also Baltimore \& Ohio R.R. v. Baugh, 149 U.S. 368, 372 (1893) (noting that because the object of diversity jurisdiction was to "institute independent tribunals which it might be supposed wonld be unaffected by local prejudices and sectional views," it would therefore "be a derehction of [the federal courts'] duty not to exercise an independent judgment in cases not foreclosed by previous adjudication" (quoting Burgess, 107 U.S. at 33-34)). 
This right to resort to a federal forum even on claims that did not raise federal questions offered protection to property and contract from both subtle and unsubtle unfairness in the state courts, and it came at a time when the Takings and Due Process Clauses would not have independently supplied protection. ${ }^{111}$ Federal diversity courts also fashioned protections against various forms of retroactive impairments to property and contract, even when the Contract Clause itself was not operative. In the federal courts' development of general constitutional lawencrusted with its government-limiting and property-protecting presumptions - natural-law influences usually associated with the later development of the Takings and Due Process Clauses during the Lochner era were already playing a major role in the interpretation of state law. ${ }^{112}$ Thus, throughout much of the nineteenth century, diversity provided a kind of nonfederal "shadow" due process that served as a model for, and provided content to, the substantive due process revolution near the century's end.

$* * *$

It would be easy to dismiss the federal courts' early treatment of state administrative bodies as a curious artifact from the long-since abandoned regine of judicial activism associated with Swift and Lochner. As we discuss below, soine aspects of this once strongly Nationalist approach admittedly have little relevance to the role of the federal courts after Erie, such as the refusal (in state-law challenges to agency action) to adhere to state rules of decision, party structure, and standards of review. But we believe that there is continuing validity to certain of the old Court's insights, especially its insistence on distinguishing between administrative process and judicial review, and its recognition that the Constitution's and Congress's jurisdictional grants call for federal court participation in the judicial review of state adninistrative action. In both state-law and federal-law challenges to agency action, the strong federal interest in providing a neutral forum for resolving issues of both law and fact still renrains, even if federal courts

111. The no-takings principle that the Court had invoked in general-law decisions such as Pumpelley v. Green Bay Co., 80 U.S. (13 Wall.) 166 (1871), was first held to be part of the concept of federal due process in Chicago Burlington \& Quincy R.R. v. Chicago, 166 U.S. 226 (1897); the protection surrounding ratemaking first became a component of federal due process in Smyth $v$. Ames, 169 U.S. 466 (1898).

112. See HoRwTIZ, supra note 100 , at 158 (emphasizing continuity rather than discontinuity in legal developinents leading to Lochner); Powe, supra note 19, at 739-40 (concluding that nineteenth century municipal bond decisions in diversity foreshadowed federal substantive due process); $c f$. James L. Kainen, Nineteenth Century Interpretations of the Federal Contract Clause: The Transformation from Vested to Substantive Rights Against the State, 31 BUFF. L. REv. 381 (1982) (fmding continuity between certain general-law principles and later developments in Lochner, but also finding differences in scope of substantive protection). 
no longer have a legitimate role to play in the fashioning of general-law norms. As discussed in Part II, we believe that these older insights have been unnecessarily slighted im the wake of the modern Court's otherwise understandable reaction to the excesses of the older regime.

\section{II}

\section{Federal Courts and Modern State Agencies}

The relationship between federal courts and state agencies obviously has undergone considerable change since the pre-administrative era. Rather than viewing themselves as equally competent with state courts in judicial review of state administrative decision unaking, federal courts are now wary of interference. To be sure, Erie now dictates that in matters not governed by federal law federal courts must conform to state-law rules of decision. But statutory provisions and judge-made nominterference doctrines also now channel many federal-law as well as state-law challenges to state agency action to state courts. In this Part, after a brief discussion of the changed legal landscape, we attempt to account for these alterations in the fabric of judicial federalism and the changing background assumptions that produced them. In Parts $\mathrm{II}$ and IV, we analyze whether federal court reluctance to review state agency action is fully justified by these changed assuinptions, and offer proposals that attempt to accommodate modern insights with what we consider to be worthy aspects of the older practices.

\section{A. Recasting Judicial Federalism}

\section{Statutory Limits on the Federal Courts}

The model for federal court nonintervention into state regulatory structures was established by statutory withdrawals of jurisdiction im the 1930s. In the Tax and Rate Injunction Acts, ${ }^{113}$ Congress withdrew the bulk of federal jurisdiction over two important subjects of local governmental regulation, so long as the state courts supplied their own "plain, speedy, and efficient" remedies. ${ }^{114}$ Federal court challenges to state agency decision inaking in these two areas had become

113. See 28 U.S.C. $\$ \S 1341-1342$ (1994). The rate statute continued to allow federal courts to address challenges based on interference with interstate commerce, see id. $\$ 1342(2)$, and the provision barring equitable relief when "[j]urisdiction is based solely on diversity of citizenship or repugnance of the order to the Federal Constitution," id. $\$ 1342(1)$, has been read as not barring challenges based on federal preemption (i.e., inconsistency with a federal statutory scheine). See, e.g., Alummum Co. of Am. v. Utilities Comm'n, 713 F.2d 1024, 1027 (4th Cir. 1983). For a discussion of the political setting of these statutes, see supra note 94 .

114. 28 U.S.C. $\$ \S 1341,1342(4)$. Prior to these acts there had been some judicial prevarication as to when it was appropriate to allow state courts to decide state-law issues. See Lifienthal, supra note 94 , at $398-99$. 
commonplace, ${ }^{115}$ and those challenges were prime targets of this early New Deal legislation.

These statutes made a dramatic impact on the past practices of the federal courts. From today's vantage point, their most visible result was to stop federal courts from entertaining equity actions raising federallaw issues, including economic due process challenges to ratemaking and taxation. But at the time they were enacted, a perhaps equally important effect of the statutes was to stop federal courts from entertaining parallel actions raising state-law issues-issues that would have then still been governed by general law in the federal courts. ${ }^{116}$ Both state and federal challenges were thereby channeled to state courts, where they would proceed in the form and mode prescribed by state law; federal court input, if any, would come only later, on direct review by the Supreme Court. ${ }^{117}$

\section{Judge-Made Abstention Doctrines}

Even without Congress's blessing, however, the Supreme Court soon developed an analogous set of judge-made nonimterference rules in areas of local governance apart from rates and taxes. ${ }^{118}$ In Burford $v$. Sun Oil Co. ${ }^{119}$ a sharply divided Court announced what many have read as a broadly applicable doctrine of "administrative abstention."120

115. See Lilienthal, supra note 94 , at $379-80$ (discussing the federal court option in challenging rate orders); see also Woolhandler, supra note 21, at 133-35, 144-48 (discussing federal court challenges to state taxes).

116. See The Tax Injunction Act, Pub. L. No. 105-175, 50 Stat. 738 (1937) (codified as amended at 28 U.S.C. $\$ 1341$ (1994)) and the Rate Injunction Act ("Johnson Act"), Pub. L. No. 105-175, 48 Stat. 775 (1934) (codified as amended at 28 U.S.C. $\S 1342$ (1994)), both preceded Erie R.R. v. Tompkins, 304 U.S. 64 (1938). The desire to stop diversity actions raising nonfederal issues was a particular impetus for the tax injunction statute. See, e.g., S. REP. No. 75-1035, at 1-2 (1937) (discussing the ability of foreign corporations to withhold taxes and bring tax-injunction suits).

117. A similar fate awaited federal court damages actions for unlawful assessinents, even though the anti-injunction statutes did not, in so many words, purport to bar post-assessment refund actions. For the somewhat tortured history, see Woolhandler, supra note 21, at 138-44 (discussing Burrill v. Locomobile Co., 258 U.S. 34 (1922), and related decisions). The modern Court rejccted federal court tax refund actions, including actions under 42 U.S.C. $\S 1983$, to redress unconstitutionally assessed taxes, in Fair Assessment in Real Estate Ass'n, v. McNary, 454 U.S. 100 (1981). Later, the Court indicated that a refund action under $\S 1983$ would also be unavailable in state court, and that state remedies would be exclusive. See National Private Truck Council, Inc. v. Oklahoma Tax Comm'n, 515 U.S. 582 (1995).

118. Arguably the Court was creating a kind of "procedural common law" out of the tax and rate injunction statutes, and related limitations on federal court equitable interference with state proceedings. For a treatment of sucl procedural common-lawinaking in the context of Supreine Court review of state court decision making, see Richard A. Matasar \& Gregory S. Bruch, Procedural Common Law, Federal Jurisdictional Policy, and Abandonment of the Adequate and Independent State Grounds Doctrine, 86 Colum. L. REv. 1291 (1986).

119. 319 U.S. 315 (1943). Justice Black authored the majority opinion, while Justices Douglas and Murphy concurred specially. Justice Frankfurter dissented for hinself and three others.

120. For the "administrative abstention" reading of Burford, see Field, supra note 2, at 1154. In praise of the general principle, see LARRY W. YACKLe, Reclaiming THE Federal Courts 262 
There, it dismissed a federal court challenge to a state agency decision regarding the allocation of in-state oil drilling rights, even though jurisdiction had been properly invoked on both federal question and diversity grounds. As did the tax and rate statutes, Burford's re-routing of such challenges to the state courts impacted not only federal law challenges to state agency action, but state-law challenges as well.

The Court's decision in Burford relied on a number of considerations, including the availability of state judicial review of the agency decision and the supposedly coinplex nature of the issues surrounding regulation of local natural resources. ${ }^{121}$ Contrary to its earlier assumptions in cases such as Reagan v. Farmers' Loan \& Trust Co., ${ }^{122}$ the Court in Burford seeined to put great weight on the state's decision to confine review of its agency's decisions to a particular state court, which it now suggested inay have developed "specialized knowledge"123 in helping to shape state policy. At the same time, the Court de-einphasized the possibility that proceedings might have moved from an administrative to a judicial stage at the point when the federal court's jurisdiction was invoked. Instead, the Court blurred the line between state agencies and state courts by characterizing them as "working partners"124 in

$\mathrm{n} .57$ (1994) (noting the general desirability of nonintervention into "particularly local affairs" such as those at issue in Burford); Calvin R. Massey, Abstention and the Constitutional Limits of the Judicial Power of the United States, 1991 BYU L. REv. 811, 812, 849-52 (1991) (suggesting Burford and other abstention doctrines inay be constitutionally required); Bezanson, supra note 2, at 1127 (concluding that Burford-style abstention "seems to benefit everyone and prejudice the legitimate interests of no one").

The American Law Institute (ALI) indicated its approval of Burford (and the model of the tax and rate injunction statutes) when it proposed that a federal district court must abstain from granting injunctive and declaratory relief respecting "any order of [a state or local] administrative agency" if:

(1) the order affects rates chargeable by a public utility, or the conservation, production, or use of minerals, water, or other like natural resource of the State; and (2) the order has been made after reasonable notice and hearing; and (3) a plain, speedy, and efficient remedy inay be had in the courts of such State; and (4) the power of the State to make such order has not been superseded by any Act of Congress or administrative regulation thereunder.

A.L.I., Study of the Division of JuRisdiction Between State and Federal Courts $\S$ 1371(b) (1969). The ALI also proposed allowing abstention when state law "cannot be satisfactorily determined" or when there was "a serious danger of embarrassing the effectuation of State policies by a decision of State law at variance with the view that may ultimately be taken by the State court, or other circumstances of like character," provided there were available state reinedies. Id. $\S 1371(\mathrm{c})$. For a critique of these particular proposals, see Currie, supra note 2, at 311-19. For a more recent ALI proposal on a related inatter and a critique of it, see infra note 218.

121. See Burford, 319 U.S. at 323-25.

122. 154 U.S. 362 (1894).

123. Burford, 319 U.S. at 327.

124. Id. at 326. Later, in Alabama Public Service Commission v. Southern Railway, 341 U.S. 341 (1951), the Court gave an expansive reading to Burford in ordering abstention froin jurisdiction over a federal constitutional challenge to a state commission's denial of a railroad's request to discontinue certain intrastate service. Noting that such railroad service involved an essentially local problein that was "primarily a concern of the state," the Court concluded that the lower court should have abstained from the railroad's due process claim that the order was confiscatory. See id. at 346 . State 
regulation and policy making-thereby implying that federal judicial participation in this mixed process was inappropriate.

As if Burford did not go far enough in this regard, the Court in Chicago, Rock Island \& Pacific Railroad Co. v. Stude ${ }^{125}$ suggested that in some settings, a federal court challenge to completed state agency action would be tantamount to an impermissible appeal from the agency to a lower federal court. ${ }^{126}$ As such, the challenge would be jurisdictionally barred. The Court reached this dubious conclusion despite the long-settled contrary presumption that the end of the administrative stage marked the beginning of an original judicial proceeding in which either state or federal courts could participate. ${ }^{127}$ As a consequence, some lower courts have since concluded that if state courts would give deference to agency decision making, an original action attacking such decision making could not be filed in the federal courts, lest they somehow be improperly converted into appellate tribunals. ${ }^{128}$

Shortly before Burford, the Supreme Court also had cut back on the federal courts' earlier practice of deciding for themselves unclear state-law questions of state agency authority arising in federal constitutional challenges to agency action. Railroad Commission v. Pullman

court judicial review was available and was concentrated in a single judicial tribunal, with de novo review of law and substantial evidence review of facts. The Court also stated that an "appeal from an order of the Commission is an integral part of the regulatory process." $1 d$. at 348 .

125. 346 U.S. 574 (1954). Stude is discussed infra in the text accompanying notes 191-194.

126. These concerns seem to echo the Court's conclusion elsewhere that lowcr federal courts cannot sit im review of state "judicial" proceedings, and that deferential review somehow meant that the agency proceedings were judicial. For example, quasi-jurisdictional principles prevent lower federal court intervention into state proceedings that have already reached a judicial phase (which, conceivably, could occur even at the agency level). See District of Columbia Court of Appcals v. Feldman, 460 U.S. 462, 476 (1983); Rooker v. Fidelity Trust Co., 263 U.S. 413, 415-16 (1923); see also Atlantic Coast Lime R.R. v. Brotherhood of Locomotive Eng'rs, 398 U.S. 281, 296 (1970) (noting, in a discussion of an anti-injunction statute, 28 U.S.C. $\S 2283$ (1994), that "lower federal courts possess no power whatever to sit in direct review of state court decisions").

127. See supra text accompanying notes 58-65; see also Note, The Supreme Court, 1953 Term: Federal Jurisdiction and Procedure, 68 HARv. L. REV. 176, 178 (1954) (criticizing Stude in hight of prior decisions recognizing the switch from an administrative to a judicial proceeding).

128. A number of federal courts have concluded, on jurisdictional (rather than abstention) grounds, that when the state courts would have supplied dcferential review to state agency action, the federal courts were not presented with a "civil action" for purposes of original jurisdiction or removal. See, e.g., Shamrock Motors, Inc. v. Ford Motor Co., 120 F.3d 196, 199-200 (9th Cir. 1997) (finding no removal); Labiche v. Louisiana Patients' Compensation Fund Oversight Bd., 69 F.3d 21, 22 (5th Cir. 1995) (finding no original jurisdiction); Fairfax County Redev. \& Hous. Auth. v. W.M. Schlosser Co., 64 F.3d 155, 158 (4th Cir. 1995) (finding no original jurisdiction); Armistead v. C. \& M. Transp., Inc., 49 F.3d 43, 47-48 \& n.4 (1st Cir. 1995) (finding no removal based on lack of original jurisdiction); $c f$. Frison v. Franklin County Bd. of Educ., 596 F.2d 1192, 1194 (4th Cir. 1979) (declining pendent jurisdiction over a deferential review clain as "essentially a petition for judicial review of state administrative action rather than a distinct claim for relief"). The status of these decisions in light of City of Chicago v. International College of Surgeons, 118 S. Ct. 523 (1997), rev'g 91 F.3d 981 (7th Cir. 1996), whicl did not address the "civil action" issue, is discussed below. See infra note 198 and accompanying text. 
Co. ${ }^{129}$ presented no new proposition in providing that antecedent questions of state law should be resolved first if their resolution could moot the need to resolve federal constitutional issues. ${ }^{130}$ But sending the statelaw question regarding the scope of agency power to state court was new. ${ }^{131}$ After Erie, of course, federal courts could no longer resolve the state-law question under principles of general law as they once would have. But the Court's solution in Pullman preempted the federal courts even from applying state law as best they could. Analogous concerns led the Court much later, albeit on sovereign immunity rather than abstention grounds, to conclude that injunctive relief against state officials' noncompliance with state law was off-limits to the federal courts altogether. ${ }^{132}$ This meant that most state-law challenges to state agency decision making (as opposed to local agency decision making) would be barred from federal courts entirely, even if they could get around the abstention limitations noted above. ${ }^{133}$

The total effect of these changes anounted to a reversal of the former practice of robust federal court review of state agency decision making. Supposedly complex regulatory schemes, and state limitations on review to particular courts, would now weigh against the exercise of federal jurisdiction. ${ }^{134}$ And the Court's unwillingness to draw distinctions between administration and judicial review-by characterizing the

129. 312 U.S. 496 (1941).

130. See Ashwander v. Tennessee Valley Auth., 297 U.S. 288 (1936).

131. See Rehnquist, supra note 2, at 1070 \& n.120. Compare Thompson v. Magnolia Petroleum Co., 309 U.S. 478, 483 (1940) (holding that while the federal bankruptcy court had exclusive control over the estate in its possession, the federal court should allow the state court to decide the undecided state-law issue of whether a railroad owned oil under its right of way or only had an easement), with Siler v. Louisville \& Nashville R.R., 213 U.S. 175, 193-94 (1909) (deciding the previously undecided state-law question, rather than deferring to the state court). Siler is discussed supra in the text accompanying notes $78-82$.

Burford was a clear step beyond Pullman because there did not appear to be any unclear questions of state law in Burford. And in Burford, unlike in Pullman, the jurisdictional basis over the state-law claim was nondiscretionary. See Burford, 319 U.S. at 317 (stating that both diversity and federal question jurisdiction had been invoked); Pullman, 312 U.S. at 498 (describing federal constitutional challenge to commission's order).

132. See Pennhurst State Sch. \& Hosp. v. Halderman, 465 U.S. 89 (1984).

133. Actions between private parties arising out of state agency action would not be barred by sovereign immunity. See, e.g., Northbrook Nat'1 Ins. Co. v. Brewer, 493 U.S. 6 (1989) (involving an insurance coinpany that sued an enployee for declaratory judgment respecting a state worker compensation board order). Federal actions against state and local officers are generally possible only when an independent action against them is available under federal law, which the tax and rate injunction acts generally disallowed. State-law damage actions against state and local officers would also be theoretically available in federal court if jurisdiction otherwise exists. Local agencies are not considered to be arms of the state, see Monell v. Department of Soc. Servs., 436 U.S. 658, 690-91 \& n.54 (1978), and rehief against them on the basis of federal law for their nnconstitutional laws, customs and policies is therefore unproblematic. Relief against them in federal court on the basis of state law would presumably depend on their suability in state court.

134. If the deeision in Chicago, Rock Island \& Pacific Railroad v. Stude, 346 U.S. 574, 580-81 (1954), is to be beheved, jurisdiction might be barred outright in some cases. 
state courts soinetimes as partners in policy making with the agencies, and sometimes as appellate tribunals-increased federal court reluctance to exercise jurisdiction. ${ }^{135}$ In addition, unclear issues of state law now gave the Court pause. All of these developinents inanifested the Court's concern with federal district judges' telling state officials how to carry out their jobs as a matter of state law, and a sense that federal courts, unlike state courts, should not be working partners in the establishment of state policy.

The Court somewhat qualified its about-face regarding review of state agency action, however, when it came to challenges based on federal law. Admittedly, Burford itself involved dismissal of a challenge that was based partly on federal grounds, and similar results were reached by the Court in other due process "reasonableness" challenges to state agency action. ${ }^{136}$ But the Court did not turn Burford into a blanket abstention doctrine prohibiting all federal challenges to state agency action. This result inay reflect the fact that many challenges to state action can now be styled as suits under $\S 1983^{137}$-claims that readily gain entry into the federal courts (as we discuss further in Part IV).

\section{B. Shifting Background Assumptions}

These statutory withdrawals and judge-inade limits on federal court jurisdiction and its exercise were the product of two related developinents. One was the inore deferential approach to economic regulation that firmly took hold during the New Deal. The desire to be rid of economic due process included with it the desire to be rid of the nonfederal shadow economic due process that diversity had traditionally provided. ${ }^{138}$ The other reason for restricting federal court review was related to Erie's rejection of general-law reasoning and its self-declared

135. The modem Court's further conclusion that certain state agency fact-findings can be preclusive in later federal court litigation further insulated state agency action from federal judicial scrutiny. See infra text accompanying notes 301-350.

136. See, e.g., Alabama Pub. Serv. Comm'n v. Southern Ry., 341 U.S. 341 (1951).

137. 42 U.S.C. $\$ 1983$ (1994). As the Court stated: "While Burford is concerned with protecting complex state administrative processes from undue federal interference, it does not require abstention whenever there exists such a process, or even in all cases where there is a "potential for conflict' with state regulatory law or policy." New Orleans Pub. Serv., Inc. v. Council of City of New Orleans, 491 U.S. 350, 362 (1989) (quoting Colorado River Water Conservation Dist. v. Unitcd States, 424 U.S. 800, 815-16 (1976)).

138. Emblematic of the new constitutional order was Justice Stone's legendary footnote four. See Umited States v. Carolene Prods. Co., 304 U.S. 144, 152 n.4 (1938). Fittingly, Carolene Products and Erie were decided on the same day. See Gardbaum, supra note 17, at 485 n.7, 550-58 (observing that the New Deal was largely an economic revolution and that the waning of substantive or economic due process at the state and federal levels was accompanied by Erie's curtailing of federal judicial power that had existed under Swift). 
embrace of positivism. ${ }^{139}$ Concerns for uniformity in the interpretation of state law and the sense that, given the commingling of powers within state courts and agencies, federal court mvolvement in state administrative action might present problems of legitimacy, seemed to argue for federal court restraint.

\section{The Retreat from Economic Due Process}

The Court's late-nineteenth-century economic due process doctrines had evolved from protection of property as a matter of general law (through diversity jurisdiction) to protection of property as a matter of due process (through federal question jurisdiction). ${ }^{140}$ As did the tax and rate injunction statutes, Burford and its antecedents show the Court retreating simultaneously on two fronts in the context of challenges to state agency action. ${ }^{141}$ First, it turned its back on economic due process challenges by watering down judicial scrutiny under the Fourteenth Amendment and subsequently eliminating lower federal court judicial scrutiny altogether in some contexts. Second, it withdrew the parallel diversity action that raised similar reasonableness challenges to state economic regulation on state-law grounds.

The coordinated nature of this retreat is borne out by the Court's decision in Railroad Commission v. Rowan \& Nichols Oil Co., ${ }^{142}$ which foreshadowed Burford. As in Burford, the plaintiff in Rowan had raised a Fourteenth Amendment economic due process challenge to a state agency's decision respecting drilling rights. Coupled with its federal claim was a pendent state-law claim (although at first the Court seemed to overlook the additional claim). ${ }^{143}$ In its initial Rowan decision, the Court reviewed and rejected the federal claim on the merits. It stressed its new-found reluctance to interfere with state economic regulation through the Due Process Clause and indicated that it would supply only

139. See Erie R.R. v. Tompkins, 304 U.S. 64, 79 (1938) (" [L]aw in the sense in which courts speak of it today does not exist without some definite authority behind it." (quoting Black \& White Taxicab \& Transfer Co. v. Brown \& Yellow Taxicab \& Transfer Co., 276 U.S. 518, 533 (1928) (Holmes, J., dissenting)); see also infra note 147 (discussing role of positivisin).

140. Thus, as discussed above, see supra text accompanying notes 84-91, the Court in Reagan $v$. Farmers' Loan \& Trust, 154 U.S. 362 (1894), reviewed the reasonableness of rates as a matter of general law in a diversity case, and later, in Smyth v. Ames, 169 U.S. 466 (1898), reviewed the same issue as a federal question.

141. See Paul M. Bator, Congressional Power over the Jurisdiction of the Federal Courts, 27 VIL.L. L. REv. 1030, 1036-37 (1981) (observing that the point of the tax imjunction statute and others like it was to give states a home-field advantage in the litigation of covered issues).

142. 310 U.S. 573 (1940).

143. See id. at 580. The Court here noted that this was a federal question case, and then incorrectly stated that the only issue was whether the vague contours of due process were transgressed. The latter statement was later ordered stricken from the opinion. See Railroad Comm'n v. Rowan \& Nichols Oil Co., 311 U.S. 614 (1940). 
the most mininial scrutiny in such challenges. ${ }^{144}$ The plaintiff sought a rehearing, however, on the ground that pendent clainis still remained, and that the confiscation inquiry under state law would have warranted greater judicial scrutiny than under the Court's highly deferential due process approach. The Court did not take the bait, however, and it turned away the long-available parallel state-law claim as well: "What ought not to be done by the federal courts when the Due Process Clause is invoked ought not to be attempted by these courts in the guise of enforcing a state statute." 145

Because the state claim in Rowan was pendent to the federal claim, the Court simply opted not to decide it. That option, of course, was not available in Burford, in which there was an independent jurisdictional basis in diversity for the state-law claim. And the Court in both cases seeined concerned that lower federal courts could not be trusted to give deference to state agencies in deciding state-law claims. ${ }^{146}$ In order for the Court to be able to guarantee the exclusion of state-law claims that tended to raise similar challenges to state regulatory action as those under federal law, it had to create the rule of abstention and dismissal that it did in Burford. The Court's procedural move thus nirrored the tax and rate statutes by forcing all claims to be pursued in state court. The statutory and judge-made restrictions on the federal courts were, of course, even stronger medicine than was diminished judicial scrutiny because certain claims would no longer be heard in the lower federal courts at all. But the Court's route of excluding federal challenges to agency action rather than relynig only on minimal scrutiny was critical to removing the availability of a federal forum for parallel state-law challenges of which the Court was especially eager to be rid.

\section{The Decline of the General Common Law}

Other related concerns accompanied the decline of economic due process and led to the federal courts' retreat from review of state agency decision inaking. The displacement of the old concept of a general common law with a new emphasis on positive law reinforced the

144. See Louis L. Jaffe, The Judicial Universe of Mr. Justice Frankfurter, 62 Harv. L. Rev. 357, 367 n.27 (1949) (stating that Rowan, although not directly touching the point, was widely cited as heralding the fall of Smyth v. Ames, 169 U.S. 466 (1898)).

145. See Rowan, 311 U.S. at 615, modifying 310 U.S. 573 (1940); see also Railroad Comm'n v. Rowan \& Nichols Oil Co., 311 U.S. 570, 576 (1941) (noting that the court below had nullified the commission's orders without even having the record of the commission before it); cf. Rowan, 310 U.S. at 584 (Roberts, J., dissenting) (noting that the action was tried de novo, without the commission's record).

146. See Burford v. Sun Oil Co., 319 U.S. 315, $327-33$ (recounting problems resulting from federal court interpretation of state law); Rowan, 311 U.S. at 572 (noting lower federal court injunction against commission orders); $i d$. at 577 (overturning state-law ground for decision (in addition to federal ground)). 
reluctance of federal courts to delve into state administrative decision making. Positivism required courts to identify rules of decision with the law of a particular sovereign-something that general-law reasoning refused to do. ${ }^{147}$ Moreover, the decline in general-law concepts was itself related to the decline in economic due process, because the latter had been grounded in common-law protections of property and contract.

Erie, a decision embleinatic of the jurisprudential move from general-law reasoming to positivism, constrained federal courts to emphasize uniformity with state decision making in claims not governed by federal law. While adherence to state rules of decision did not itself dictate a withdrawal of federal jurisdiction im state agency cases, ${ }^{148}$ some extensions of the einphasis on positive law and uniformity appeared to justify limitations on the exercise of federal jurisdiction. Particularly, the federal courts became concerned that an undecided issue of state law would reduce the federal courts to making a mere "forecast" 149 of state law. And the loss of general law property-protecting presumptions exacerbated the concern about such forecasts. Old presumptions regarding delegation, public-purpose limitations on governmental action, and valuation of property had all helped the Supreme Court decide a variety of issues of state administrative law. But with its increasing acceptance of economic regulation, the Court was no longer confident in applying its anti-regulatory presumptions and government-limiting default rules.

Erie's concern for uniformity carried over not only into rules of decision that federal courts would employ, but into underlying forms of action as well. As discussed in Part I, federal courts had long customized nonfederal claims to accommodate them to the strictures of federal

147. See Borchers, supra note 15, at 115-16 (viewing the jurisprudential move from general law to positivism as a "revolution in legal philosophy"); Clark, supra note 2, at 1479 \& n.102; see also supra note 15 (discussing the ineaning of positivism). The classic judicial formulation of positivism is that of Justice Holmes, in which he stated that "[t] he common law is not a brooding omnipresence in the sky, but the articulate voice of some sovereign or quasi-sovereign that can be identified." Southern Pac. Co. v. Jensen, 244 U.S. 205, 222 (1917) (Holmes, J., dissenting). Holmes's "brooding omnipresence" language lately has been referred to as an unfair characterization of Swift. See Goldsmith \& Walt, supra note 15, at 680-90; Lessig, supra note 15, at 1793 \& n.50. But right or wrong, his perspeetive appears to have been the Court's in Erie. See Erie R.R. v. Tompkins, 304 U.S. 64, 79 (1938) (observing that Swift erroneously relied upon "the assumption that there is 'a transcendental body of law outside of any particular state but obligatory within it unless and until changed by statute"' (quoting Black \& White Taxicab \& Transfer Co. v. Brown \& Yellow Taxicab \& Transfer Co., 276 U.S. 518, 533 (1928) (Holmes, J., dissenting))).

148. See Young, supra note 2, at 883-86 (characterizing Burford as inconsistent with Erie); cf. Currie, supra note 2, at 214 (seeing abstention for unclear issues of state law as the "antithesis" of Erie).

149. Railroad Comm'n v. Pullman Co., 312 U.S. 496, 499 (1941) (Frankfurter, J.); see also Chicago v. Fieldcrest Dairies, 316 U.S. 168, 172 (1942) (ordering Pullman abstention after concluding that federal court interpretation of an ordinance would "not be anything more than a forecast"); cf. Burford, 319 U.S. at 339-40 (Frankfurter, J., dissenting) (arguing that state law was sufficiently settled that federal courts would not be engaged in forecasting). 
jurisdiction. Once the cause of action that the federal courts enforced was viewed as coming from either state law or federal law, however, it tended to follow more closely the form prescribed by the sovereign that created it. This development had several important implications. The mability to modify state-law actions against arms of the state into suits against mdividual officers provided a nondiscretionary limit on federal jurisdiction over such actions. ${ }^{150}$ And the Court's eventual decision to make sovereign immunity a barrier to state-law based claims for injunctive relief against state-level officers provided a further limitation. ${ }^{151}$ But these limitations affected only nonfederal claims, and were somewhat offset by $\S 1983$ 's availability as an all-purpose means for raismg most federal constitutional challenges to state action, mcluding claims for injunctive relief against state as well as local officials. ${ }^{152}$

Even when these limitations did not foreclose federal jurisdiction over challenges to agency action based on state law, however, post-Erie federal courts were arguably under an obligation to adhere to standards of review that would have applied in state court. Thus, the federal equity practice of giving de novo review to state-law issues that might have received more deferential treatment in state court came to an end. Adherence to state deferential standards of review proved troubling, however, in that it led the Court to see state administrative and judicial process as less distinct from one another and more as points along a continuum.

\section{Commingling Court and Agency Functions}

Given the Court's loss of confidence in applying its older presumptions as a guide im deciding unclear issues of state law, an opposite set of presuniptions began to take root: namely, that government in general, and agencies in particular, were presumed to have wide-ranging powers to regulate economic matters. ${ }^{153}$ These were powers, moreover,

150. See Ford Motor Co. v. Department of Treasury, 323 U.S. 459, 463-64 (1945) (characterizing state taxpayer's action for a refund not as a general-law action to recover from the collector personally but as a statutory action against a state agency barred by the Eleventh Amendment).

151. See Pennhurst State Sch. \& Hosp. v. Halderman, 465 U.S. 89, $97-98$ (1984); Young, supra note 2, at 919-20 (noting that Pennhurst had the effect of eliminating many potential Burford abstention cases).

152. 42 U.S.C. $\S 1983$ (1994). Nevertheless, $\S 1983$ was long hamstrung by a narrow construction that limited it to claims of deprivation of liberty rather than property. See Hague $v$. Committee for Indus. Org., 307 U.S. 496 (1939) (noting that $\$ 1983$ claims are limited to deprivations of liberty not property), overruled by Lynch v. Household Fm. Corp., 405 U.S. 538 (1972). See generally Michael G. Collins, "Economic Rights," Implied Constitutional Actions, and the Scope of Section 1983, 77 GEO. LJ. 1493, 1533-37 (1989) (noting historical restrictions on constitutional litigation under $\S 1983$ ). Even today, takings claims are somewhat more difficult to bring in lower federal courts than other constitutional challenges. See infra note 276.

153. See Gardbaum, supra note 17, at 486-88; $c f$. Thompson v. Consolidated Gas Utils. Corp., 300 U.S. 55, 75 (1937) (questioning a lower federal court's narrow construction of delegation to an 
that could easily be delegated, and that were not limited by restrictive notions of public purpose or by fixed ideas regarding valuation of property. The consequence of these changed presumptions was to accord states considerable latitude in structuring their governmental institutions without interference froin older general-law presuinptions regarding state separation of powers.

\section{a. State Courts as Sources of State Law and Policy}

Erie importantly minimized the distinction between judge-1nade and legislator-made law. State judicial decisions achieved a kind of parity with state legislative decisions, and both became legitimate sources of state positive law, supplying relevant rules of decision for federal courts. ${ }^{154}$ That state courts might perform non-judicial functions was not a foreign concept even before Erie (although extreme deviations were not the norm). ${ }^{155}$ Indeed, Erie's multifunctional approach to court decision making had been heralded by Justice Holmes's opimion for the Court in Prentis $v$. Atlantic Coast Line Co. ${ }^{156}$ a seemingly benign opinion from a Nationalist federal courts perspective. Holmes had found state judicial review of agency-set rates in Prentis to be a continumg part of the legislative process because state law expressly empowered state courts to modify the agency's rates and set their own. Yet there were not light years of difference between declaring a rate unreasonable (a judicial function) and entering a reasonable one (a legislative function, according to Prentis). The decision thus seemed to imtroduce an additional level of complexity imto the characterization of state judicial action. ${ }^{157}$

agency under state statute, but holding that the act as broadly construed violated the federal Constitution).

154. See Erie R.R. v. Tompkins, 304 U.S. 64, 78 (1938) ("[W] hether the law of the State shall be declared by its Legislature in a statute or by its highest court in a decision is not a matter of federal concern."). Erie concluded that state judge-made law was among the "laws" of the states to which federal courts were required to adhere under the Rules of Decision Act, currently codified at 28 U.S.C. $\$ 1652$ (1994) (requiring federal court adherence to state laws except when federal law "otherwise requires or provides"). See Erie, 304 U.S. at 71-73; cf. HART \& WECHSLER, supra note 3, at 1256 (noting that a rationale for abstention was that state courts and administrative agencies inake law). For an account of Erie with an emphasis on how the decision fit with the New Deal revolution in judicial federalism, see Gardbaum, supra note 17, at 11, 551-53. Although Professor Gardbaun rightly sees Erie as part of a larger constitutional agenda, he approaches Swift and Erie as imphicating state regulatory interests as they impacted private-law disputes. We suggest that Swift also had an important public-law dimension to which Erie also put a halt.

155. See, e.g., Bacon v. Rutland R.R., 232 U.S. 134, 137-38 (1914) (finding that legislative powers had not been conferred on state courts). A corollary was that agency action not yet complete could not form the basis of a federal court challenge.

156. 211 U.S. 210 (1908); see also Oklahoina Natural Gas v. Russell, 261 U.S. 290, 291 (1923).

157. See Paul M. Bator et al., Hart \& Wechsler's The Federal Courts and the FEDERAL SYSTEM 1189-90 (2d ed. 1973) (discussing confusion in lower courts arising froin uncertainty of agency-court relationships); see also Jaffe, supra note 144, at 357, 359 n.4 (noting that states had stripped their highest courts of "legislative" duties to avoid the various embarrassments of Prentis). Characterizing judicial review as legislative or judicial was not always an easy task, even 
Prentis, however, did not exclude the lower federal courts from exercising judicial review; it merely postponed such review until the "legislative" process was over-i.e., until the state courts were done. ${ }^{158}$ By contrast, Burford's conclusion that "no useful purpose" 159 would be served by attempting to characterize the role of the state courts in reviewing agency decision making as either legislative or judicial meant that lower federal courts might be foreclosed from judicial review altogether. Regulated parties might be caught in a jurisdictional catch-22, in which judicial review could be nonjudicial enough to exclude the lower federal courts at the conclusion of the agency's actions, yet judicial enough to foreclose federal court review after the state courts' actions. ${ }^{160}$

\section{b. State Agencies' Exercise of Mixed Functions}

The line blurring between state legislative and judicial branches was accompanied by the blurring of all three branches within agencies themselves. Agencies exercised not only executive functions, but legislative and judicial functions as well. ${ }^{161}$ When combined with interbranch confusion within state courts, interbranch confusion within agencies made the assessment of when judicial process began and agency process ended even more problematic. ${ }^{162}$ Moreover, the prevalence of statutory deferential review procedures exacerbated the difficulty. When agency process fed into statutory deferential review in the state courts, judicial

though it was one that mattered to the pre-Burford Court. See, e.g., Detroit \& Mackinac Ry. v. Michigan R.R. Comm'n, 235 U.S. 402, 405-06 (1914) (finding the state proceeding had been judicial, although the state supreme court had said that the duty of the court was not essentially different from that of the commission).

158. Until the Rate Injunction Act, Pub. L. No. 105-175, 48 Stat. 775 (1934) (codified as amended at 28 U.S.C. $\S 1342$ (1994)), Prentis meant that regulated parties in some states had two bites at the apple-once in the state courts, and then again in federal court, when the state-court legislative process had been concluded. Note that there may still be issues concerning when an agency itself has acted with finality. See, e.g., McChord v. Louisville \& Nashville R.R., 183 U.S. 483, 495 (1902); New Orleans Water Works Co. v. New Orleans, 164 U.S. 471, 472 (1896). See generally Lilienthal, supra note 94 , at $385-88$ (discussing timing of federal court review).

159. Burford v. Sun Oil Co., 319 U.S. 315, 325 (1943).

160. See, e.g., District of Columbia Court of Appeals v. Feldman, 460 U.S. 462,464 (1983). In Feldman, the plaimtiff had sought a waiver of a bar admissions rule, first by applying to the Committee on Admissions from which he received an informal hearing. The Committee instructed him that only the District of Columbia Court of Appeals could grant a waiver. The plaintiff proceeded to request a waiver by a petition and arguments submitted by letter. See id. at 464-68. Despite the fact that the proceedings (even the one before the local court) appeared to involve licensing, the Supreme Court characterized them as sufficiently judicial to foreclose later federal trial court review of them. See id. at 479.

161. See LANDIS, supra note 100, at 1,47-50; see also HoRwitz, supra note 100 , at 217 (stating that Landis attacked the conceptualism of attempts to fit agencies into traditional separation of powers thinking).

162. See Moore \& VanDercreek, supra note 68, at 303 \& n.34 (gathering decisions that considered statutory review of an administrative proceeding as a continuation of the administrative process and therefore not removable). 
process and agency process seemed even less distinct, and simultaneously suggested that state agencies were acting in a judicial capacity and state courts in a policy making one. In either event, federal court intervention was more problematic than before.

$$
* * *
$$

The inodern era thus saw a dramatic reaction, if not an overreaction, to the older Court's approach to state administrative review. As we have described, one inpetus for the retreat was the decline in economic due process and an accompanying desire not to allow lower federal courts to disinter it under the guise of deciding related state-law issues. Another concern was an ill-formed conviction that judicial review of state agency action amounted to something other than an original judicial proceeding, which, if undertaken by the federal courts, would mipermissibly mvolve them either in state policy making or appellate review. Related concerns were grounded in the Erie-based fear that federal courts would make mere forecasts of state administrative law by deciding issues im ways contrary to how state courts would later resolve them, and, in the process, unduly impair the administration of state public law.

\section{III}

\section{State-Law Challenges to Agency Action IN THE FEDERAL COURTS}

Whether the Court was right to develop its administrative noninterference doctrines and, if so, what their proper scope should be, are normative issues that the next two Sections will address. In developing our critique, we rely on some of the discarded imsights of the pre-New Deal federal courts, while accepting that Erie and the decline of economic due process have fundamentally changed the role of such courts and, along with it, the balance of judicial federalisin. We therefore seek a middle ground between the extremes of the "Nationalist" perspective of the early federal decisions addressing state agencies and the "Federalist" perspective of the later era.

In this Part, we consider how the Court might better address statelaw challenges to state administrative action ${ }^{163}$ that arise through diversity jurisdiction. In general, we question the extent to which the blurring

163. We use the term "state administrative action" throughout our discussion in this Part and in Part IV to refer to either state or local agencies. However, as we have elsewhere noted, federal courts may entertain state-law based injunctive actions only against "local" (as opposed to "state") agency action, given sovereign immurity concerns. See supra text accompanying note 151; infra note 233. That limitation is inapplicable to challenges to agency action based on federal law, however. See infra text accompanying note 289. 
of separation-of-powers lines within and between state courts and agencies calls for removmg federal courts from judicial review of state agency action. In particular, we consider arguments that deferential review of agency action poses a stumbling block to federal judicial review by inappropriately involving federal courts in state policy inaking or appellate review. In accordance with older practices, we conclude that judicial review of agency action normally should be distinguished from agency action, and that such review should be considered an original civil action that can be entertained by the federal district courts. We subsequently explore whether the need for decisional uniformity in the wake of Erie may be overstated, and overbalanced by the continuing role of diversity jurisdiction in supplying a fair forum for diverse litigants. Although there may no longer be any cognizable federal interest in deciding issues of state law differently from how the state courts would decide them, we conclude that there remains a federal interest in resolving undecided issues of state law when such a decision could, as diversity jurisdiction presupposes, be tainted by bias against out-of-state regulated parties.

\section{A. Federalism and Jurisdiction}

It might be possible to deal with the abstention aspects of the modern Court's nominterference principles simply by denying the constitutional legitimacy of judge-crafted abstention altogether as violating separation of powers. Some federal courts scholars have so argued. ${ }^{164}$ Much of the pre-New Deal history of judicial review of state administrative action, moreover, suggests that federal courts were unflinching in the exercise of their jurisdiction. Other scholars have countered by findmg legitimacy in federal equity courts' historic practice of declining remedies that are "discretionary" in nature. ${ }^{165}$ From the perspective of federalism, the equitable-discretion argument has a certain appeal insofar as it tempers the impact of wide-open jurisdictional grants in ways that are more state-respecting, even if its historical pedigree is open to question. ${ }^{166}$

164. See Martin H. Redish, Abstention, Separation of Powers, and the Limits of the Judicial Function, 94 YALE L.J. 71 (1984); see also Cohens v. Virginia, 19 U.S. (6 Wheat.) 264, 404 (1821) (stating that "[w]e have no more right to decline the exercise of jurisdiction which is given, than to usurp that which is not given"); cf. Colorado River Water Conservation Dist. v. United States, 424 U.S. 800,817 (1976) (noting that federal courts are under a "virtually unflagging" obligation to exercise jurisdiction properly invoked).

165. See, e.g., David L. Shapiro, Jurisdiction and Discretion, 60 N.Y.U. L. REv. 543, 579-80 (1985); see also Quackenbush v. Allstate Ins. Co., 517 U.S. 706, 718-20 (1996) (apparently limiting Burford abstention principles to suits involving equitable rehief).

166. Cf. Barry Friedman, A Different Dialogue: The Supreme Court, Congress, and Federal Jurisdiction, 85 Nw. U. L. REv. 1, 2-3 (1990) (arguing that the scope of federal jurisdiction involvcs dialogue between Court and Congress); Michael Wells, Why Professor Redish Is Wrong About 
However this theoretical debate may be resolved, as a practical matter, it is likely that some version of these federalism-inspired limits are here to stay, even if the contours of abstention $m$ any particular setting remaim subject to dispute. And one need not doubt the constitutionality of all abstention to conclude that, in this, as in other contexts, insufficient consideration has been given to Congress's grants of original jurisdiction and how they will be affected by the exercise of abstention. ${ }^{167}$ Even though some critics have expressed doubts about the continued need for certain categories of federal jurisdictionparticularly diversity jurisdiction ${ }^{168}$ - they remain a given whose provision and presumed purposes the judicial branch is obliged to honor. Moreover, it must be supposed that, in making those jurisdictional grants, Congress acted upon assumptions about mstitutional disparities between state and federal courts for resolving not just questions of fact, but questions of law and issues of law-apphication as well. Such legislative assumptions about possible shortcomings of the state courts would be, of course, in tension with the contrary assumptions about the adequacy of state courts that underlie the abstention doctrines. ${ }^{169}$ In this Part (and the next), we do not seek to eliminate this tension, but to fine-tune it and to assess the proper scope of administrative abstention and certain related principles, while still accepting its basic legitimacy.

Abstention, 19 GA. L. REv. 1097, 1132-33 (1985) (suggesting that judge-made federalism limits on federal courts supply an antidote to judge-made expansions in jurisdiction and federal rights).

167. Professor Barry Friedman has provided an imsightful look at abstention in general from this perspective. See Friedman, supra note 2 . He argues that the propriety of abstention is best assessed by focusing on the extent to which a federal trial court forum is needed, as opposed to an appellate federal forum on direct review from the state courts. See id. at 537-38. In particular, he argues that issues of fact present a compelling case for lower federal court involvement because of the difficulty of considering such issues only on direct review. We agree with his focus on the need for a federal trial forun, although we also contend that the resolution of issues of law and law-application (including issues involving state law in diversity cases), not just fact, may present a compelling case for lower federal court involvement. See infra text accompanyimg notes 240-258. And although Professor Friedman acknowledges the problem of fact-finding bias in the administrative review context, see Friedman, supra note 2, at 584-88, he ultimately concludes that the state interests in such cases are sufficient to justify the absence of lower federal court input, although lie calls Burford a "close case" im light of his own approach. See id. at 588.

168. See, e.g., Federal Courts Study, supra note 5, at 38-39; Henry J. FrIENdLy, Federal JURISDICTION: A GENERAL VIEW 138-52 (1973); Larry Kramer, Diversity Jurisdiction, 1990 BYU L. REv.97; see also ChEMERINSKY, supra note 5, $\$$ 5.3.2 (discussing modern debate). It is not our purpose here to provide a full-blown defense of diversity jurisdiction in general or in specific settings. Like the rennedy under 42 U.S.C. $\$ 1983$ (1994), it is one that Congress has provided without requiring the party who invokes it to show that the purposes of the statute are being met in the particular case, prejudice in judicial contexts being notoriously hard to prove.

169. See Friedman, supra note 2, at 532,540-41 (noting conflicting premises of jurisdictional grants and abstention as to adequacy of state forum); see also George D. Brown, When Federalism and Separation of Powers Collide-Rethinking Younger Abstention, 59 Geo. WASH. L. REv. 114, 114 (1990) (noting similar conflict in the Supreme Court's professed commitment to federalism and separation of powers). 


\section{B. Erie's Impact on Judicial Review of State Agency Action}

A few_matters seem settled in Erie's wake. Actions for review of state administrative action based on nonfederal grounds are now properly viewed as deriving from state law rather than general law. In such situations, federal courts ordinarily should follow the substantive rules of decision that state courts have developed. In addition, the basic party structure of such state-law causes of action should be replicated in federal courts. Thus, to the extent that state law makes a state agency or other arm of the state a proper defendant to a state-law action for review of agency decision making, federal courts should honor that choice and bar the action on sovereign immunity grounds. ${ }^{170}$ Erie alone might counsel the abandonment of the federal courts' prior practice of substituting non-immune individual defendants in a state agency's place; but the Court's sovereign immunity decisions now directly bar statelaw-based injunctive actions against state officials as well. Indeed, discussion of abstention in state-law actions in federal courts prinuarily has meaning today with respect to claims against local governmental entities, agencies, and officials who are not considered arms of the state for sovereign immunity purposes. ${ }^{171}$ The upshot of these developments is that, quite apart froin the proper scope of abstention doctrines, possible federal-court interference with legitimate state-level policy making is already greatly miniumized.

In addition to conforming to state forms of action, federal courts should also be bound by the record and standards of review of agency action that the state courts would employ. Although standards of federal appellate court review of lower federal court decision making in diversity cases inay deviate froin state law, ${ }^{172}$ no similar federal interest is in1plicated in the exercise of original federal court jurisdiction over state agencies. ${ }^{173} \mathrm{By}$ contrast, the state's interest in allocating policy making to agencies to whoin deference might be due as a matter of state law is

170. See supra notes 150-151; cf. FED. R. C1v. P. 17 (stating that real party in interest is determined by reference to state law). Federal courts, however, can still ignore certain state forms in certain circumstances. For example, the fact that a state denominated review as "mandamus" did not stop federal courts from entertaining such actions. See supra notes 40-44 and accompanying text. Similarly, the fact that a state provides for review in an appellate rather than a trial court, should not block the federal courts from considering such actions as original district court proceedings.

171. See Young, supra note 2, at 919-22, 934 (noting that sovereign immunity effectively preempts the need for administrative abstention in equitable challenges to state agency action based on state law).

172. The Seventh Amendment, for example, limits federal court review of fact-finding by juries in common-law actions, U.S. CoNST. amend. VII, and FED. R. C1v. P. 52 limits review of fact-finding by federal judges. A federal court would be bound by those limits in a diversity action, contrary state law notwithstanding.

173. Cf. Gaspermi v. Center for Humanities, Inc., 518 U.S. 415, $436-38$ (1996) (altering a lower federal court's ordimary review of jury decision making respecting damages to accommodate a state policy on standards of review that would exist on appeal from the state trial court). 
substantial. Erie therefore strongly suggests that lower federal courts adhere to state standards of review in such cases.

There are, nevertheless, a number of possible objections to federal courts' engaging in judicial review of agency action on state-law grounds at all. One set of objections focuses on the blurring of separation-of-powers lines flowing from the embrace of positivismobjections that are voiced most frequently when state courts engage in deferential review of agency action. These separation-of-powers concerns lead to alternative objections: that federal review of state administrative action would involve federal courts in either state policy making or appellate review. A second set of objections results from the emphasis on the uniformity that flows from Erie's requirement that federal courts adhere to state rules of decision. The concern is that federal courts will decide issues of state administrative law differently from how state courts would decide them. As discussed below, these rationales for disabling federal courts from review of agency action on state-law grounds (whether on abstention or jurisdictional grounds) unduly slight the continued federal interest in providing a neutral forum to out-of-staters for questions of both law and fact.

\section{Deferential Review as "Policy Making"}

One objection to federal court review of state administrative action is that state courts and state agencies are partners in policy making - an objection that particularly surfaces when the state courts would engage in statutory deferential review of agency action. ${ }^{174}$ By contrast, federal court review of state administrative action has proved relatively unproblematic when review of administrative action is de novo, as it typically was in the nineteenth century. De novo review, whether conducted by state or federal courts, could readily be viewed as an original judicial proceeding that either court system could undertake. As foreshadowed in Burford, however, deferential review was cause for hesitation by the federal courts. The Court im Burford saw judicial review as a continuation of agency process, and saw the state courts and agencies as partners in state policy inaking ${ }^{175}$-a legislative role for state courts that Erie also recognized. ${ }^{176}$ Federal court involvement in such an ongoing process was thought to cast federal courts in an unfamiliar policy making role.

The objection that deferential review unduly involves the federal courts in state policy making, however, is unconvincing. It is hard to disagree with the observation that governmental branches are not always readily distinguishable, or that common-law courts are often involved in

174. See Moore \& VanDercreek, supra note 68 , at 303 \& n.34, 317-18.

175. See Burford v. Sun Oil Co., 319 U.S. 315, 325-26 (1943).

176. See supra note 154 and accompanying text. 
law-making rather than mere law-discovery. This recognition, however, does not distinguish modern courts from those of the past-except to the extent that the lawmaking role of courts may have once been less explicitly recogmized than it is today. ${ }^{177}$ Even though deferential review of state administrative action may seem somehow less appropriate for federal courts than de novo review, the reasons underlying this instinct are less than compelling.

First, it is illogical to view deferential review as more intrusive on state administration than de novo review; ${ }^{178}$ de novo review actually gives the courts a greater role in lawmaking than does deferential review. The decrease in the lawmaking role of courts through deferential review is underscored by the Supreme Court's decision in Chevron U.S.A., Inc. v. Natural Resources Defense Council, ${ }^{179}$ which told the federal courts to uphold reasonable federal agency interpretations of federal statutes. ${ }^{180}$ To the extent that federal courts employed comparable deference (if called for by state law) in reviewing state administrative action, their interference with state policy making and lawmaking would be less, not greater. ${ }^{181}$ In fact, now that the old presumptions against delegation and economic regulation have been supplanted with perhaps an opposite set of presumptions, the real risk may be that federal courts will be less inclined to second-guess state administrators than would a state court. It surely would be an odd result if, as has occasionally happened, ${ }^{182}$ local

177. Even at the time of Swift, contemporary critics were hardly oblivious to the possibility that common-law decision making implicated a legislative function. See HoRwITz, supra note 47, at 17. 18 (discussing antebellum codification movement as grounded in distrust of "ex post facto" commonlawmaking); Lessig, supra note 15, at 1492-94.

178. See, e.g., Burford, 319 U.S. at 341 (Frankfurtcr, J., dissenting) (noting that the scope of judicial review under state law was clear, involving an inquiry as to whether sufficient facts existed for a reasonable mind to enter the order, or whether the agency exceeded its power).

179. 467 U.S. 837 (1984).

180. Chevron effectively created a presumption that Congress means to delegate lawmaking authority when it creates agencies to administer federal regulatory scliemes. See 467 U.S. at 843-44. See generally Henry P. Monaghan, Marbury and the Administrative State, 83 ColuM. L. REv. 1, 6 (1983) (explaining that judicial deference to agency decisions of law results from the agency's exercise of delegated lawmaking power).

181. See Keith Werhan, Delegalizing Administrative Law, 1996 U. ILL. L. REv. 423, 457-58 (noting that Chevron's net effect was to diminish judicial powcr and enhance agency power). Of course, if it is determined that the state courts are courts in name only and that they perform traditional legislative functions (as when setting rates), lower federal court review of the agency's actions before further state "court" cousideration would impermissibly interfere with the ongoing legislative process. Cf. Supreme Court of Virginia v. Consumers Umion, 446 U.S. 719, 731 (1980) (noting that state judges acted as legislators when promulgating rules governing state bar). But the state courts' standard of review of agency action slould not be of mucl aid in making that determination.

182. In City of Chicago v. International College of Surgeons, 118 S. Ct. 523 (1997), for example, the City of Chicago successfully sought removal from a state court of a judicial-review proceedingfiled by the International College of Surgeons - of a local zoning board decision favorable to the City of Chicago. Cf. Louisiana Power \& Light Co. v. City of Thibodaux, 360 U.S. 25, 36 (1959) (Brennan, 
agencies rather than regulated parties had the greater incentive to seek out the federal courts for review of agency action. The possible problein of "too much" deference, however, can be addressed, as we have suggested, by careful attention to state standards of review. In any event, in light of changed federal presumptions and Erie's insistence on adherence to state standards, Burford's concern that federal courts deciding state administrative law issues would reintroduce substantive due process through the back door of diversity - a real enough risk at the time of Burford-now seems chimerical.

What is more, despite the modern tendency to emphasize the branches' overlapping functions and the dovetailing of administrative and judicial process through statutory review, it still remains possible to distinguish "judicial" action from "administrative" action" ${ }^{183}-$ regardless of whether the administrative action might be characterized as primarily executive, legislative, or judicial. ${ }^{184}$ In addition to providing heightened formality of procedures, judicial process attempts to focus on certain more legalistic aspects of problems initially decided by agencies-including, for example, the scope of their authority or whether they have addressed relevant statutory considerations. These characteristic differences remaim, and are arguably heightened, when courts engage in deferential rather than de novo review. The older, more formal approach to separation of powers that saw judicial review of state agency action as distinguishable from administrative action (and by extension an appropriate task for either state or federal courts with jurisdiction) thus continues to provide a fair description of state institutional arrangements.

Not only is it ordinarily possible to distinguish agency action from judicial action, it also better accords with constitutional and statutory jurisdictional grants and with state and federal notions of due process to do so. The old Court's recognition of a distmct judicial phase in the review of state agency action had long been propelled both by a sense that judicial process was essential to due process, and by a sense that state institutional arrangements should not operate to diminish federal

J., dissenting) (noting that the city urged the district court to litigate the state-law issue on which the federal court abstained).

183. See generally William A. McGrath et al., Project: State Judicial Review of Administrative Action, 43 ADMIN. L. REv. 571, 593-97 (1991) (indicating that separation of powers doctrines at the state level tend to resemble separation of powers doctrines at the federal level).

184. We lere address a general distinction between agencies and the judiciary. As we discuss more fully below, the fact that agencies engage in certain judicial functions does not mean that judicial review of their action is inevitably appellate and thus for state courts only. See infra text accompanying notes 188-219. In addition, in the context of uniformity, we discuss Erie-driven arguments that equate judgments and legislation. See infra text accompanying notes 224-233. 
jurisdiction. ${ }^{185}$ Granting that state separation of powers remains largely a matter within state control, and that it is difficult to delineate with precision when federal due process would require states to provide judicial review of agency action, it is nevertheless difficult to imagine that the states' institutional arrangements would or ultimately could exclude some form of judicial review of important regulatory activity. ${ }^{186}$ Indeed, the states' own routine provision of judicial review shows that they regard a distinctly judicial phase as promoting administrative legitimacy ${ }^{187}$ and as enhancing checks and balances by preventing undue concentrations of power through use of a multilayered decisional process. And, as discussed more fully below, federal courts can further ensure fairness for out-of-staters by providing, as Congress has called for, an intergovernmental check. Thus, despite the difficulties of determining when federal due process requires states to provide judicial review of state-law issues, the question of whether state court review of state agency action is indeed judicial should proceed from the presumption that it is just that.

The notion that federal courts should abstain (or be jurisdictionally disabled) on the ground that state courts reviewing agency action would be involved in some between-the-branches forms of administration therefore obfuscates the important role of the regular court system within the admimistrative state. For that reason, the premise of decisions such as Burford that state judicial review involves mixed functions may not provide a particularly reliable starting point for judging the propriety of abstention.

\section{Deferential Review as "Appellate" Process}

Another aspect of the federal courts' tendency to cloud the relationship between courts and agencies is to see agency process as judicial, and to see deferential review by the courts as amounting to "appellate" review of a subordinate judicial body. Consequently, many federal courts have concluded that lower federal court review of agency action

185. In the past, the most controversial aspect of requiring judicial process was a rcquirement of de novo review for some issues, such as confiscation and jurisdictional fact. See supra note 100. While the requirement of de novo review has largely lapsed, see STEPHEN G. BREYER ET AL., Administrative LAW AND REgulatory Policy 138-39 (4th ed. 1998), the idea that the availability of judicial review is required to validate agency action remains embedded in our legal system. See id. at 864-67 (discussing the issue of when due process requires judicial process). The precise contours of a judicial process requirement, however, are unclear.

186. But cf. Daniel J. Meltzer, Legislative Courts, Legislative Power, and the Constitution, 65 IND. LJ. 291, 298 (1990) (suggesting that a single, fair administrative determination might satisfy due process in many contexts).

187. See generally McGrath et al., supra note 183, at 577, 698-704 (describing the ubiquity of judicial review in state systems); see also Judith Resmick, Tiers, 57 S. CAL. L. REv. 837, 850 (1984) (discussing values of duplication in decision making). 
on state-law grounds would be improper, because it would convert courts of original jurisdiction into appellate courts by interjecting them into the middle of ongoing state judicial process. ${ }^{188}$ As we conclude in this Section, however, the preferable characterization of even deferential judicial review of agency action is that it is an origmal civil action-in keeping with past practices of allowing federal courts to consider "appeals" from state agencies. What is more, the Supreme Court's recent decision in City of Chicago v. International College of Surgeons ${ }^{189}$ may be a welcome step in recognizing that federal courts can readily accommodate deferential review and the exercise of original jurisdiction. ${ }^{190}$

\section{a. Murky Precedents}

Most of the modern rhetoric about lower federal courts not acting as appellate courts can be traced to the Supreme Court's decision in Chicago, Rock Island \& Pacific Railroad Co. v. Stude. ${ }^{191}$ There, expressly relying on Burford, the Court upheld dismissal-for lack of subject matter jurisdiction-of an original diversity action challenging the lawfulness (on state-law grounds) of a state agency's orders in a condemnation proceeding. Ignoring a good bit of history, the Court declared that lower federal courts do "not sit to review on appeal action taken administratively or judicially in a state proceeding." 192 Although the dismissal was based on jurisdictional rather than abstention grounds, ${ }^{193}$ the decision built on Burford's studied refusal to provide a close look at the functions performed by state agencies and the courts that review thein. Perhaps the Court in Stude was struck by the fact that the plaintiff had styled his coinplaint in federal court as an "appeal" froin the state agency (as it would have been called in state court). Nevertheless, the Court also appeared to assume-perhaps inconsistentlythat removal of the agency review proceedings from state to federal court would have been possible had it been sought by a defendant to those state court proceedings. ${ }^{194}$

188. See cases cited supra note 128.

189. 118 S. Ct. 523 (1997).

190. In this setting, we use the term "original" jurisdiction to refer to trial jurisdiction that federal courts could exercise either on removal of a suit from state court, or when a suit is filed in federal court initially.

191. 346 U.S. 574 (1954).

192. Id. at 581 . See also supra note 126 (noting the presence of similar jurisdictional concerns in other contexts).

193. The Court decided that the original proceeding in federal court was not a "civil action" within the meaning of the diversity statute, 28 U.S.C. \$ 1332 (1994). See Stude, 346 U.S. at 581.

194. See Stude, 364 U.S. at 581. Stude's reasoning is difficult to decipher. The logical consequence of considering any review of agency proceedings as appellate would be to eliminate federal trial court jurisdiction over state agency action in nearly every setting, whether or not 
In a later decision that involved judicial review of a Texas worker compensation hearing, the Court upheld original federal court jurisdiction, and distinguished Stude, by observing that Texas did not consider the review stage to be an "appeal," but rather a "trial de novo wholly without reference to what inay have been decided" by the agency. ${ }^{195}$ But a state's choice of label for its judicial-review proceeding had never been a sticking point for the Court in the past, ${ }^{196}$ and the state scheme at issue in Stude also involved de novo, not deferential review. ${ }^{197}$ The Supreme Court's effort to distinguish Stude in this manner may, however, have fueled lower federal courts in supposing that anything less than de novo review was appellate review, in which the lower federal courts could not properly engage. ${ }^{198}$

\section{b. Appellate Versus Original Judicial Process}

While judicial review of agency action could be characterized as appellate, such a characterization is not inevitable. Admittedly, it is not irrational to consider deferential federal court review of agency action to be appellate, given that much administrative action is routinely characterized in the federal and state systems as "adjudication." 199 This characterization is reinforced by the fact that in the federal and in soine state systems, review of administrative action may feed into courts of

deferential review would attach. In addition, removal jurisdiction, which the Stude Court concluded could exist, is itself premised on the existence of original jurisdiction, which it concluded did not exist. See HART \& WECHSLER, supra note 3, at 738-39. It is virtually impossible to reconcile these two conclusions.

195. Horton v. Liberty Mut. Ins. Co., 367 U.S. 348, 355 (1961).

196. See, e.g., Pacific R.R. Removal Cases, 115 U.S. 1, 6 (1885) (noting that the state considered review of agency action to be an "appeal"); see also supra text accompanying notes 100-103.

197. See Stude, 346 U.S. at 576; see also City of Chicago v. International College of Surgeons, $118 \mathrm{~S}$. Ct. 523, 532 (1997) (correctly characterizing Stude as involving a trial de novo). In fact, a prior version of the very agency-review scheme at issue in Stude had proved not to be a stumbling block to federal court review (on removal) of state agency action at the turn of the century. See Mason City \& Fort Dodge R.R. v. Boynton, 204 U.S. 570 (1907).

198. See cases cited supra note 128. Because jurisdiction over the state-law deferential review claim was upheld on grounds of supplemental jurisdiction alone in College of Surgeons, lower federal court decisions that involved original or removed civil actions in diversity were not overruled. Nevertheless, the diversity-based state-law claims have at least as strong (if not strongcr) claim on the federal courts as do the pendent state-law claims, which, by statute, a fedcral court might choose not to hear in some settings. See 28 U.S.C. \$ 1367(c) (1994).

199. See Uniform LaW Commissioners' Model State Administrative Procedure Act $\S \$$ 3-101 to $-214,4-101$ to -506 (1981) (describing procedures for mlemaking and adjudication respectively). In the Federal Administrative Procedure Act, for example, all that is not "rulemaking" is considered to be "adjudication," which is then broken down into "formal" and "informal" adjudication. See 5 U.S.C. $\$ 551(4)-(7)$ (1994) (definitions); id. $\$ 554$ (prescribing procedures for "adjudication required by statute to be determined on the rccord after opportunity for an agency hearing"). In the context of state official action generally, it is hard to suppose that all nonrulemaking activity would be judicial in a sense that would render it inappropriate for federal court scrntiny. 
appeal rather than trial courts. ${ }^{200}$ At a loose level of generality, moreover, all judicial review of official action is a kind of appeal.

On the other hand, the possible characterization of judicial review of administrative action as appellate review does not mean that it might not just as appropriately be viewed as an "original" proceeding. Federal district courts as well as appellate courts entertain deferential review of federal administrative agency decisions. To the extent that judicial review under the Administrative Procedure Act (APA) ${ }^{201}$ takes place in district courts, the review proceeding must be considered an "original" civil action, whether or not review is deferential. ${ }^{202}$ Deferential review has become a pervasive feature of original district court cases reviewing state executive action, and sometimes even cases reviewing state judicial action. ${ }^{203}$ Certamly there is nothing judicially unmanageable in a federal district court's accordmg deference to some other decision maker. The question then, is not whether review of state administrative action can be pigeon-holed as appellate or original, but which treatment is preferable given the demands of federal jurisdiction and the interests of federalism. ${ }^{204}$ In any event, it should be a question of federal law as to when a proceeding amounts to an original civil action for purposes of federal trial court jurisdiction, state labels or characterizations notwithstanding.

There may be good reasons to retain the historically grounded presumption that judicial review of agency action is an original judicial proceeding, even when review is deferential. ${ }^{205}$ Past practice suggests some reasons why the first step from an agency into the regular court system ordinarily should be considered an origmal action-i.e., one filable in federal court in the first instance, or removable to federal court

200. See Michael Asimow et al., State and Federal Administrative Law 613 (2d ed. 1998) (noting that in most states judicial review begins at the trial court level).

201. 5 U.S.C. $\$ \S 551-559,701-706$ (1994).

202. See BREYER ET AL., supra note 185 , at 807 (noting that federal statutes may prescribe review either in an appellate or district court); $i d$. at.976-79 (describing the use of general federal question jurisdiction as a basis for challenges to agency action where the organic statute does not provide specifically for statutory review).

203. Lower federal courts give deference to state decision makers in a variety of contexts. In constitutional hitigation, federal courts apply deference to state (and federal) executive decision makers in decidimg whether officials have acted reasonably although unlawfully, so as to entitle them to qualified immumity in damages actions. See, e.g., Harlow v. Fitzgerald, 457 U.S. 800, 818 (1982) (involving a federal official). On federal habeas corpus federal courts routinely give deference to state court fact-finding as well as to state court decisions on questions of federal law. See 28 U.S.C. § 2254(d)(1)-(2) (Supp. II 1996) (limiting habeas to violations of "clearly established" federal law, or when a decision "was based on an unreasonable determination of the facts"); see also Teague v. Lane, 489 U.S. 288, 299 (1989) (limiting habeas review of issues involving a "new rule" of law).

204. Cf. Williamson B.C. Chang, Rediscovery of the Rooker Doctrine-Section 1983, Res Judicata and the Federal Courts, 31 Hastings LJ. 1337, 1354 (1980) (defining "appeal" as any claim that could not be brought as an original action because it is barred by a previous judgment).

205. Cf. Louis L. JafFe, Judicial Control of Administrative Action 425 (1965) (noting that in Anglo-American law, administrative agencies are not a part of the judicial system). 
by the defendant if filed in state court. The Supreme Court long ago observed that states should not be allowed to structure their own judicial review so as to frustrate federal jurisdiction. ${ }^{206}$ The implication was that a state's curtailment of federal concurrent jurisdiction-whether deliberately or as a by-product of otherwise legitimate structuring of state institutions - was contrary to the diffusion of power contemplated in our federal system. ${ }^{207}$

What is more, insisting that judicial input at the conclusion of agency action be considered appellate could also lead (at least in theory) to peculiar results. If one accepts the premise that states cannot undercut federal jurisdiction while keeping their own institutions of judicial review intact, and if agency proceedings are considered sufficiently judicial so that subsequent review is truly appellate, then in some cases federal courts may arguably have concurrent jurisdiction of the original proceeding that one would expect to take place in the agency ${ }^{208}$ This "judicial" characterization of agency action, if applied too broadly, has the potential to interfere with state institutions even more than would allowing for concurrent jurisdiction later, at the point of formal judicial review following final agency action. ${ }^{209}$ Thus, the better approach from the perspective of federalism would be to resist routine characterization of the first point of judicial review of agency action as appellate rather than original.

206. See Reagan v. Farmers' Loan \& Trust Co., 154 U.S. 362, 391 (1894). There might be cases in which the state provided for no judicial review even in state courts, and where due process did not require it. The federal courts in such circumstances could not review the agency's decisions any inore than the state courts could. See supra notes 74-76 (discussing tax assessment decisions). But the fact that a state could have dispensed with judicial review, but did not, should not mean that federal judicial review is unavailable. If a state decides that the trappings of judicial review matter, and is unwilling to inake the difficult pohtical decision to cut off such review-a decision that would affcct in-staters and out-of-staters alike-the jurisdictional choices usually available to out-of-state litigants should continue to apply at the point of judicial review.

207. That a state might channel its appeals to a single court could reflect an effort to avoid conflicting judicial decisions regarding an agency's actions. See Burford v. Sun Oil Co., 319 U.S. 315 , 326 (1943); see also CHEMERINSKY, supra note 5, § 12.2.3 (noting that Burford turned on the lack of clarity of state law and the need for "centralized administration"). See generally infra text accompanying notes 301-315 (discussing fact-fmding uniformity). But it is not clear why such an effort should ordinarily have transjurisdictional consequences that would make otherwise available federal courts unavailable. If the concern is avoidance of nonuriformity through the suppression of multiple judicial voices, it can, as discussed below, be dealt with in less drastic ways that give greater respect to Congress's jurisdictional choices. See infra text accompanying notes 234-239. To the extent that the state reviewing court has achieved the goal of uniformity, the federal courts will have that much easier a time imitating state decisions.

208. See infra note 219.

209. Moreover, review of state agency action typieally begins in state trial rather than appeals courts. See AsIMOW ET AL., supra note 200, at 613. This would likely be especially true of local agency action. That state review might go to a state court of appeals, however, should not bc determinative that the action is appellate, given the malleability of the appellate/original characterization. As discussed above in Part I, federal courts have routinely customized state forms to the extent necessary to allow for federal jurisdiction. 


\section{c. Stude's Uncertain Future}

The Supreme Court may be poised to embrace an approach that rejects an appellate characterization of deferential review of agency action, Stude notwithstanding. In City of Chicago v. International College of Surgeons, ${ }^{210}$ the Court faced the question of whether a state-law claim seeking review of a local zoning board decision could be properly removed to federal court when the state claim would have merited deferential review in state court. The plaintiff brought the state claim together with a federal constitutional challenge to the board's actions and both claims were removed after suit was filed in state court. ${ }^{211}$ Citing Stude, the Seventh Circuit concluded that the state-law deferential review proceeding was not an origmal "civil action" subject to the jurisdiction of the federal courts under the removal statutes. ${ }^{212}$

The Supreme Court managed to avoid deciding the original-civilaction question, as well as the continuing validity of Stude as it impacts original jurisdiction. Instead, it reasoned that the supplemental jurisdiction statute ${ }^{213}$ authorized the addition of "any claim" with a sufficient nexus to another claim (such as the constitutional challenge) that was properly subject to federal jurisdiction-whether or not the state-law claim would qualify on its own as a "civil action" within the original jurisdiction of the federal courts. ${ }^{214}$ The Court stated that it was precisely the purpose of the supplemental jurisdiction statute to pick up claims that could not have been filed in federal court on their own. ${ }^{215}$ It therefore upheld removal of both claims, although it suggested that the lower courts might, on remand, consider the propriety of abstention. ${ }^{216}$

The Court's decision to uphold jurisdiction in College of Surgeons makes sense, but its analysis is problematic. Surely the supplemental

210. 118 S. Ct. 523 (1997).

211. The federal challenge was not brought in state court as an action under 42 U.S.C. $\S 1983$ (1994), but as part of the state statutory review proceeding as allowed for under state law. The Court upheld federal question jurisdiction on removal because the plaintiff's well-pleaded complaint established that its right to relief under state law required resolution of a substantial federal question. See College of Surgeons, 118 S. Ct. at 533-34; see also Smith v. Kansas City Title \& Trust Co., 255 U.S. 180 (1921) (upholding jurisdiction when the federal question arose on the face of the plaintiff's well-pleaded state-law cause of action).

212. See International College of Surgeons v. City of Chicago, 91 F.3d 981, 990 (7th Cir. 1996), rev'd, 118 S. Ct. 523 (1997).

213. 28 U.S.C. $\$ 1367$ (1994). The statute provides in relevant part that "in any civil action of which the district courts have original jurisdiction, the district courts shall have supplemental jurisdiction over all other claims that ... form part of the same case or controversy." Id. $\$ 1367$ (a).

214. See College of Surgeons, 118 S. Ct. at 531.

215. See id. at 533-34.

216. See id. The removal statute provided for the removal of any civil action over which the district courts have original jurisdiction. See 28 U.S.C. $\$ 1441$ (a)-(b) (1994). The Court read the statute as allowing for removal of a civil action that was in the configuration of a federal claim with a pendent state-law claim because that entire combination could have been filed as an original matter in federal court. See College of Surgeons, $118 \mathrm{~S}$. Ct. at 533-34. 
jurisdiction statute allows the joinder of state-law claims that could not satisfy federal jurisdiction because of some subject-matter failing such as lack of diversity or the absence of a federal question. But it is questionable whether the statute allows joinder of additional claims by plaintiffs that could not be filed in (or removed to) federal court on their own because they were not "civil actions" within the meaning of those federal jurisdictional provisions. ${ }^{217}$ Instead of offering an unlikely reading of the supplemental jurisdiction statute, the Court ought to have concluded that the deferential-review claim under state law was indeed a civil action, and upheld removal on that basis. ${ }^{218} \mathrm{Had}$ it done so, however, the Court might have had to come to grips with Stude, at least to the extent that Stude imght be read as holding that a case involving deferential review of agency decision making cannot constitute an original civil action in the federal courts. Should it confront this aspect of Stude in the future, the Court should overrule it outright, or at least make clear that Stude does not render deferential review of state agency action off-limits to lower federal courts, either as a jurisdictional inatter or as a matter of abstention. ${ }^{219}$

217. Whether claims by others, such as intervenors, might not have to amount to "civil actions" on their own is another question. See Richard A. Matasar, Rediscovering "One Constitutional Case": Procedural Rules and the Rejection of the Gibbs Test for Supplemental Jurisdiction, 71 CALIF. L. Rev. 1399, 1414-17 (1983).

218. Indeed, the College of Surgeons Court seemed inclined to see on-the-record judicial review as an original civil action, see $118 \mathrm{~S}$. Ct. at 532-33, although its opinion ultimately relied on a possible distinction between supplemental and original jurisdiction. Nevertheless, the American Law Institute (ALI) has proposed revision of College of Surgeons, on the ground that it supposedly conflicts with the historic role of the federal courts, and because it allows federal courts to entertain "appellate" cases. See A.L.I., supra note 11, at xix-xx. See also Joan Steinman, Crosscurrents: Supplemental Jurisdiction, Removal, and the ALI Revision Project, 74 IND. LJ. 75, 86-88 (1998) (endorsing the ALI's criticism of College of Surgeons). Insofar as the historic role of the federal courts is concerned, the ALI is simply mistaken. And, as we have argued in this Section, it is doubtful whether agency review claims should be considered appellate rather than original.

Although the ALI's proposal only purports to address supplemental jurisdiction under 28 U.S.C. $\S$ 1367 (1994), its conclusion that the sort of state-law administrative-review claim involved in College of Surgeons is appellate and not original might also suggest that a federal claim such as the one in College of Surgeons was itself appellate and not original for purposes of federal question jurisdiction under 28 U.S.C. $\$ 1331$ (1994). In addition, such a conclusion would seem to deny original jurisdiction over even a nonsupplemental state-law based claim as a matter of diversity jurisdiction under 28 U.S.C. $\S 1332$ (1994). Oddly, the route taken by the ALI to achieve its result is to make clear in its revision of $\$ 1367$ that supplemental jurisdiction only attaches to clains that would be within the federal courts' original jurisdiction. See A.L.I., supra note 11, at 1-2. If, however, we are correct that administrative review claims are really part of the federal courts' original jurisdiction, then the ALI proposal would have no effect at all, other than to add unnecessary confusion by proposing a change that did not achieve its stated purpose.

219. It might be possible to proceed from a somewhat more functional perspective, and to recoginze that some agency action could be so highly formal that any subsequent federal review would have to be considered impermissible cross-appellate review from a subordinate state judicial body. Cf. HART \& WechsLer, supra note 3, at 643 \& n.12 (observing that there may be no "federal criterion that distinguishes state 'courts' ... from other state tribunals that engage in adjudication"); Meltzer, supra note 186, at 297-301 (making a similar observation). Under a more functional 


\section{Uniformity's Limits and the Role of Diversity}

Even accepting the unremarkable proposition that judicial review of state administrative action is ordinarily a judicial (and nonappellate) task, it is still arguable that state courts alone are the appropriate bodies to review state administrative action. Such arguments stem from Erie's seeming equation of state judgments and state legislation, and they are implicated whether state judicial review of agency action is deferential or de novo. Similar concerns may be expressed in Burford's characterization of state agencies and courts as partners in policy making.

Because state courts, even im the exercise of ostensibly judicial functions, mevitably make state law when they decide cases, one might doubt whether federal courts can play any legitimate role in reviewing state agency action. Moreover, these legitimacy concerns feed into a basic tenet of federalism that allocates to the state and federal governments their respective lawmaking functions so that the lines of political accountability remain visible. ${ }^{220}$ These legitimacy and federalism

approach, the results of an agency's "formal adjudication" might be considered the product of a judicial proceeding subject to "appellate" review in the state courts alone.

There are, however, serious difficulties with such an approach. First of all, if an agency proceeding were treated as the equivalent of a court proceeding, then the agency procecding itself in some instances might amount to an original "civil action" within the meaning of federal jurisdictional provisions. As such it could be arguably filed in a lower federal court in the first instance or reinoved there if filed in the agency. Compare, e.g., Kolibash v. Committee on Legal Ethics, 872 F.2d 571 (4th Cir. 1989) (upholding removal of state bar disciplinary proceedings by a federal officer under 28 U.S.C. $§ 1442$ (a) as a "civil action"), and Tool \& Die Makers Lodge No. 78 v. General Elec. Co., 170 F. Supp. 945 (E.D. Wis. 1959) (upholding removal of a worker compensation proceeding before a state "board" as a "civil action," observing that federal jurisdiction would have existed over a particular claim brought before the board under federal labor laws), with Village of Walthill v. Iowa Elec. Light \& Power Co., 228 F.2d 647 (8th Cir. 1956) (deciding that a proceeding in a state condemnation "court" was not a removable "civil action"). Given the vast number of state proccedings that would qualify as "formal adjudication" under state administrative law provisions, this would be a highly problematic development from the perspective of federalisin, even when the administrative proceeding was not in the nature of an enforcement action. When the initial state proceeding (as opposed to review thereof) is thought inappropriate for Article III courts-for example, licensing or permitting proceedings-the reasons for treating only the first step of judicial review thereafter as the commencenent of judicial process seems soinewhat easier. $C f$. Alleghany Corp. v. Haase, 896 F.2d 1046, 1049-50 (7th Cir. 1990) (observing that a federal court could take review of an agency's permit denial and accord the agency's findings precisely the effect that a state court would give them on direct review), vacated on grounds of mootness and res judicata sub nom. Dillon v. Alleghany Corp., 499 U.S. 933 (1991).

In addition, by employing a functional analysis, the mitial agency phase might be termed both administrative, thus excluding the federal courts pending the outcome of such process, and judicial, so that further review would have to be considered truly appellate, and the federal courts would be excluded after the initial proceeding. This catch-22 scenario can best be avoided by presuming that judicial review of an initial agency decision-including decisions such as permitting and licensing-is itself the heginning of an original "judicial" phase, even if the agency proceedings carry with them a significant degree of formality.

220. See, e.g., Printz v. United States, 117 S. Ct. 2365, 2377 (1997) (holding unconstitutional a federal requirement that state officers conduct background checks on handgun purchasers); New 
concerns, however, ultimately run up against the grant of diversity jurisdiction. To the extent that abstention doctrines remain in tension with the Constitution's and Congress's jurisdictional grant of diversity jurisdiction, legitimacy concerns weigh against abstention as well as in favor of it. ${ }^{221}$

Perhaps because competing legitimacy concerns are present whether the federal courts decide or declime to decide state-law issues, such concerns tend to be filtered through the lens of uniformity. ${ }^{222}$ From that perspective the question becomes whether it is ever appropriate for federal courts to decide issues of state law, particularly undecided issues, im a manner that might be different from the way the state courts would decide them on review from a state agency. In this Section we argue that this rigid insistence on uniformity in civil judgments has failed to account for the continuing place of diversity in providing fairness to out-of-staters in keeping with its historic role. ${ }^{223}$ Despite Erie, it is still appropriate in most cases for federal courts to decide issues of state law to protect against possible state judicial bias, even at the risk of some nonuniformity in outcomes.

\section{Lawmaking by Judgment Versus Lawmaking by Legislation}

The concern that only state courts should engage in state lawmaking via judicial review of agency action stems in part from the positivist view of decisions such as Erie that judgments make law. But the lawmaking in which courts engage differs importantly froin ordinary, legislative lawmaking. Judginents make law in the sense of providing the rule in a given case, but that rule is only directly applicable between

York v. United States, 505 U.S. 144, 168-69 (1992) (invalidating a federal statute requiring states either to take title to certain radioactive waste or regulate pursuant to Congress's dircction).

221. Moreover, there niay be reason to believe that the constitutional and statutory rationale for diversity of protecting out-of-staters las not lost its generative force, as discussed below. See infra text acconipanying notes 240-261.

222. See Wells, supra note 2, at 77 (noting that "disruption" of a state regulatory scheine ordinarily has to do with a federal court's possible errors in ruling on questions of state (not federal) law); $c f$. FEDERAL CouRTS STUDY, supra note 5, at 617 (purporting to limit Burford to "cases [that] turn] on debatable issues of state law" and in which "the state courts have a quasi-administrative, policy-making role"). Note that another kind of uniformity concern may be present when the proceeding imvolves limited resources or presents similar multi-party zero-sum problems. See infra text accompanying note 236 .

223. Cf. Byrd v. Blue Ridge Rural Elec. Coop., Inc., 356 U.S. 525 (1958) (allowing the jury in a federal diversity action to resolve the question whether plaintiff was a statutory employce under state law whose sole reniedy would be workers' compensation, even though, in state court, a judge would ordinarily have resolved the question on direct review of proceedings before a worker compensation board). Given decisions such as Byrd, different possible outcomes are tolerated to accomnodate federal interests in constructing their own procedures, the Rules of Dccision Act, 28 U.S.C. $\$ 1652$ (1994), notwithstanding. Similarly, properly promulgated federal rules under the Rules Enabling Act, 28 U.S.C. $\$ 2072$ (1994), can trump state practice even though sucl rules may result in different outcomes from those that state courts might reach. See, e.g., Hanna v. Plunier, 380 U.S. 460 (1965). 
parties to the judgment. ${ }^{224}$ State courts are hardly obligated to follow a federal court's erroneous ruling on a question of state law in later litigation involving different parties. And the stare decisis value of a federal court's erroneous decision even in later federal litigation will be negligible if intervening changes in state law demonstrate the error. ${ }^{225}$ In short, both the inherent limitations of a judgment and the malleability of the law it creates support the notion that the lawmaking work of the judiciary is in important respects distinct from that of legislatures. Fimally, constitutionally grounded presumptions favoring concurrent state and federal jurisdiction, both im diversity and federal question litigation, indicate that the interstitial lawmaking of judicial decision making need not always occur in the courts of the sovereign that created the cause of action, ${ }^{226}$ even if it might be assumed that those courts would be better at the job. ${ }^{227}$

224. The modern emphasis on courts as lawmakers and on "public law litigation" as distinct from "bipolar" litigation has undermined the sense that a judgment is meant to determine low the state will exercise power primarily as between the parties, with a mere precedential effect as to nonparties. See generally James Wm. Moore \& Thomas S. Currier, Mutuality and Conclusiveness of Judgments, 35 TUL. L. REV. 301 (1964) (defending requirement of mutuality of estoppel).

225. See generally Jed I. Bergman, Note, Putting Precedent in Its Place: Stare Decisis and Federal Predictions of State Law, 96 Colum. L Rev. 969 (1996) (contending that federal courts are too defercntial to federal precedent construing state law); see also Charles L. Gowen \& William H. Izlar, Jr., Federal Court Abstention in Diversity of Citizenship Litigation, 43 TEX. L. REv. 194, 213 (1964) (noting the limited effect of a "wrong" decision of a federal court in the diversity context).

226. It is true that state courts ordinarily do not exercise concurrent jurisdiction over federal admimistrative action, even if it would be theoretically possible. See Meltzer, supra note 186, at 299301; cf. Akhil Reed Amar, Of Sovereignty and Federalism, 96 YALE L.J. 1425, 1509-10 (1987) (positing a state supervisory role over federal official wrongdoing). But the lack of state judicial control over federal officers througl imjunctive-type relief, even outside of administrative schemes, is a pervasive feature of our federal system. See, e.g., Tarble's Case, 80 U.S. (13 Wall.) 397, 404, 409 (1871) (holding that a state judge lacks jurisdiction to issue a writ of habeas corpus for the discharge of a person held under federal authority); see also M'Clung v. Silliman, 19 U.S. (6 Wheat.) 598, 604 (1821) (holding that a state court cannot issue mandamus to a federal officer); Richard S. Arnold, The Power of State Courts to Enjoin Federal Officers, 73 YALE L.J. 1385, 1386-93 (1964) (discussing the prohibition on states issuing writs of habeas corpus and mandamus to federal officers, but arguing for more latitude to issue injunctions). By contrast, federal judicial review of state official action is equally pervasive. See, e.g., Brown v. Board of Educ., 347 U.S. 483 (1954) (involving an imjunction to reform state institutions); Brown v. Allen, 344 U.S. 443 (1953) (involving federal habeas corpus for state prisoners); cf. Monroe v. Pape, 365 U.S. 167 (1961) (involving a constitutional tort damages action agaimst state or local officers), overruled in part on other grounds by Monell v. Department of Soc. Servs., 436 U.S. 658 (1978). While doctrines of equitable restraint will exclude federal court interference with state enforcement actions, see Younger v. Harris, 401 U.S. 37 (1971), sucl actions probably have the strongest claim to being decided in the courts of the same sovereign that is seeking enforcement. See Ann Woolhandler \& Michael G. Collins, State Standing, 81 VA. L. REv. 387, 43538 (1995).

227. See Michael Wells, Naked Politics, Federal Courts Law, and the Canon of Acceptable Arguments, 47 EMORY L.J. 89, 105, 152 (1998) (noting that within the traditional federal courts paradigm - in whicl it is tolerable for there to be only a "weak parity" between state and federal courts-uniformity concerns are often trumped by other values). 
It might be supposed, however, that federal court review of state administrative action is inherently more problematic than other diversity cases im this regard. Federal judgments in state-law administrative cases can have greater impact than in litigation between purely private parties because government is a repeat player. Under modern notions of nonmutual collateral estoppel, a litigant who lost on an issue of state law in federal court could be precluded from relitigating that question in a later action even agaimst a different party. Applying such notions to state governmental parties might pose risks to local self-governance, well beyond the preclusive impacts on state law connected with more ordinary private litigation. 228

The Supreme Court may have been moved by similar concerns in Louisiana Power \& Light Co. v. City of Thibodaux, ${ }^{229}$ which raised the prospect of a federal court hazarding a wrong guess on an unclear question regarding a municipality's power to condemn property under state law. That a federal court could tell a city that it had a power under state law that a state court might later conclude other cities generally lacked, or that it lacked a power which others generally had, presented troubling prospects for the states' ability to empower and shape their own governmental structures in a constitutionally nonoffensive manner. Similarly, structural injunctions and institutional reform ordered by federal courts on the basis of state law raise issues of federalism sufficiently compelling that they drove the Supreme Court to find sovereign immumity objections when such orders were directed at state officials. ${ }^{230}$

228. There are already limitations upon nonmutual collateral estoppel against the federal government. See United States v. Mendoza, 464 U.S. 154, 162 (1984) (holding nonmutual offensive collateral estoppel inapplicable against the federal govemment). It would seen appropriate to recognize a similar limitation on nonmutual collateral estoppel where the federal courts have decided state-law issues respecting state governmental entities that the state courts might later wish to decide differently. See Note, Nonmutual Issue Preclusion Against States, 109 HARV. L. Rev. 792 (1996) (arguing that nonmutual issue preclusion should be presumptively unavailable against state governments to allow states to develop their own law); $c f$. Young, supra note 2, at 963 (observing that the problem of federal court litigation involving multiple similar cases, as in Burford, "deprive[s] state courts of the opportunity to elaborate policy"). Indeed, there is probably already enough flexibility under the current law to deny nonmutual collateral estoppel in such cases. See REsTATEMENT (SECOND) OF JUDGMENTS \& 29(7) (1982) (listing as a consideration against allowing nonmutual issue preclusion that "the issue is one of law and treating it as conclusively determined would mappropriately foreclose opportumity for obtaining reconsideration of the legal rule upon which it is based").

229. 360 U.S. 25 (1959).

230. See Pennhurst State Seh. \& Hosp. v. Halderman, 465 U.S. 89 (1984). Some have argued that surgical use of abstention rather than sovereigu immunity to address such problems might have been preferable. See David L. Shapiro, Wrong Turns: The Eleventh Amendment and the Pennhurst Case, 98 Harv. L. Rev. 61 (1984); Keith Werhan, Pullman Abstention After Pennhurst: A Comment on Judicial Federalism, 27 WM. \& MARY L. Rev. 449 (1986). Whether or not Pennhurst was correct as a matter of sovereign immunity law, we are sympathetic to its suggestion that, at least in the context of complex injunctive relief, federal courts ordinarily ought not to be in the business of "instruct[ingl state officials on how to conform their conduct to state law." Pennhurst, 465 U.S. at 106; see also Ann 
Nevertheless, circumscribing nonmutual collateral estoppel may alleviate some of the worst problems of a federal court's overdetermining state law when the litigating party is a local government, its agencies, or officials. ${ }^{231}$ Limiting nonmutual estoppel tends to make judgments Inore judicial and less legislative by limiting a judgment's impactbeyond its effect as between the litigants - to its stare decisis effect, as opposed to formal preclusion. To the extent an action is mjunctive, the federal courts' liberality in granting relief from judgment because of later changes of law can often rescue parties, including governmental parties, who continue to be bound by a federal court's imterpretation of state law that is later rejected by the state courts. ${ }^{232}$ But if a serious question regarding the structure of state government or the powers of local entities or officials is raised in a case arising from agency action, and such safeguards are unlikely to be effective, abstention or certification ${ }^{233}$ may be im order.

Althouse, How to Build a Separate Sphere: Federal Courts and State Power, 100 HaRv. L. REv. 1485, 1521-27 (1987) (noting that the mechanism for correction of federal court error is more problematic in the context of mjunctions against state officials); John P. Dwyer, Pendent Jurisdiction and the Eleventh Amendment, 75 CALIF. L. REv. 129, 161-67 (1987) (suggesting Pennhurst should be limited to state-law claims for imstitutional reform).

231. See Note, supra note 228 , at $799-800$. But cf. id. at $797 \mathrm{n} .41$ (finding nonmutual issue preclusion against local (as opposed to state) governments and their officials to be less objectionable). The binding effect of a federal court judgment on a state court proceeding is generally thought not to be a question involving the full faith and credit statute, 28 U.S.C. $\$ 1738$ (1994), whose terms only refer to the preclusive effect of state court decision making, but of the Supremacy Clause, U.S. CoNST. art. VI, cl. 2. See Stephen B. Burbank, Interjurisdictional Preclusion, Full Faith and Credit and Federal Common Law: A General Approach, 71 CoRNeLl L. REv. 733, 739-47 (1986); see also Stephen B. Burbank, Federal Judgments Law: Sources of Authority and Sources of Rules, 70 TEx. L. REV. 1551, 1553-56 (1992).

232. See Rufo v. Inmates of Suffolk County Jail, 502 U.S. 367 (1992) (involving reform of an cquitable decree); see also FED. R. Clv. P. 60(b) (allowing for reopening of judgments im limited circunstances); cf. United States v. Beggerly, $118 \mathrm{~S}$. Ct. 1862, 1868 (1998) (holding, in a case involving a quiet title action, that a "grave miscarriage of justice" is required to support an independent action to reopen a judgment under Rule 60(b)). Intervening changes in state law might arguably allow for a reconsideration of inatters determined in a condenmation setting between the parties to a prior federal court action when the local government was (erroneously) deried powers it possessed under state law. But see Clark, supra note 2, at 1509-13 (noting that some lower federal courts are unwilling to use their powers under Rule 60(b) im reopening actions at law, even in light of changes in state law).

233. Certification of unclear questions of state law directly to a state supreme court that is willing and able to take such questions will be authoritative and nore expeditious than abstention (which contemplates the filing of a declaratory action with a state trial court and state court appeals thereafter). See Arizonans for Official Englisil v. Arizona, 117 S. Ct. 1055, 1074-75 (1997). Certification is also arguably more respectful of Congress's jurisdictional grants than those forms of abstention, sucli as Burford, that would otherwise result in dismissal, rather than a mere postponenient of the federal proceedings. See Clark, supra note 2, at 1549-56. But certification is not always available froin district courts as opposed to federal appellate courts, even when state law otherwise provides for certification. See Paul A. LaBel, Legal Positivism and Federalism: The Certification Experience, 19 GA. L. REv. 999, 999 n.1 (1985); see also Bergman, supra note 225, at 1000-01 \& nn.187-97 (discussing limitations on certification). And it is not clear whether federal courts that can resort to certification should be able to do so in circumstances that would not otherwise warrant 


\section{Abstention and Judgments with Class-Wide Fallout}

A prototypical scenario in which a federal judgment might have the effect of seriously impeding a subsequent state court interpretation of state law could arise in a federal proceeding involving a highly inclusive class of litigants. In such a case, the public and private parties to the suit would be barred by res judicata from seeking an alternative determination in state court, at least until the state courts could address similar questions involving other parties, or intervening state legislation made clear the federal courts' error. In the interim, the state's opportunity to develop policy would effectively be taken froin it. ${ }^{234}$ Should such problems arise, federal courts ought to be wary of class actions challenging agency action on state-law grounds. Alternatively, the federal courts might consider such cases appropriate for certification or abstention, especially if state law is unclear. ${ }^{235}$

abstention. The Supreme Court seems to have given its blessing to certification in cases in which federal constitutional questions might be avoided by certifying unclear questions of state law, as in Arizonans for Official English, as well in diversity cases, see Lehman Bros. v. Schein, 416 U.S. 386 (1974); Clay v. Sun Ins. Office, Ltd., 363 U.S. 207 (1960). The use of certification in diversity cases is more problematic from the perspective of jurisdictional policy, however, and is in tension with the Court's conclusion in Meredith v. Winter Haven, 320 U.S. 228, 234 (1943), that abstention is not justified by the mere presence of unclear questions of state law in a diversity case. See also Lelmian Bros., 416 U.S. at 390 ("[T] he mere difficulty in ascertaining local law is no excuse for remitting the parties to a statc tribunal...."). In this respect, we disagree with Professor Bradford Clark's suggestion that certification should be presumptively favored to resolve any potentially unclear statelaw questions. See Clark, supra note 2, at 1544-53; see also infra text accompanying notes 246-258.

234. Cf. Richard A. Posner, The Federal Courts: Challenge and Reform 217-18 (1996) (noting that, as a general matter, diversity "can interfere with the development of state law," but also noting a particular problem with diversity mass-tort class-action litigation involving multistate plaintiffs in which general legal principles rather than state law are sometimes applied). Perhaps a problem could arise if ongoing statc regulation involved large numbers of out-of-staters who were able to repair regularly to the federal courts. But it is hard to imagine that the same issues and fact patterns would not come up in the state courts in connection with in-state regulated parties, thus allowing the state courts to have the last word as to the meaning and application of their own law.

235. Compare Louisiana Power \& Light Co. v. City of Thibodaux, 360 U.S. 25 (1959), with County of Allegheny v. Frank Mashuda Co., 360 U.S. 185 (1959). Mashuda was another eminent domain diversity case, but unlike in Thibodaux, the Court rejected abstention, observing that state law regarding what was a taking of property for public use was "clear and certain," Mashuda, 360 U.S. at 196. The Mashuda decision strongly suggests that the presence of questions of eminent domain is, standing alone, an insufficient reason for a federal court to abstain. See id. at 192 (stating that "eminent domain is no more mystically involved with 'sovereign prerogative' than a State's power to regulate fishing in its waters"); see also FED. R. Crv. P. 71A (outlining procedures for hearing condemnation actions in federal court). In light of Mashuda, the result in Thibodalux might suggest that unclear questions of eminent domain law are enough for abstention. See Thibodaux, 360 U.S. at 30 (Stewart, J., concurring) (noting that state law in Mashuda was "clear and only factual issues nced be resolved"). But cf. Quackenbush v. Allstate Ins. Co., 517 U.S. 706, 720-21 (1996) (atteinpting to harmomize Thibodaux and Mashuda by focusing on the fact that the district court in Thibodaux, but not Mashuda, purported to retain jurisdiction). But, even the presence of unclear questions of eminent domain law should not, im most cases, be a sufficient basis for abstention absent the sort of class-wide impacts that we have described. But see Ryckman, supra note 2, at 396-440 (inaking an argument for inucl broader abstention in sucl contexts). 
A like rationale may argue for abstention when resolution of the state-law issues arising from agency action would impact government or nonparties in a manner closely approximating the binding class treatment noted above. For example, it is possible that some proceedings regarding an agency's allocation of natural resources could approximate traditional in rem actions. Such proceedings can have mevitable and largely irreversible inpacts on others who inay not be formally present in the litigation and, if entertained by the federal courts, could disable a state from making a contrary disposition of property or resources. ${ }^{236}$ They also often require uniformity, not $m$ the sense of conformity to particular substantive standards, but in the sense of requiring a single or unified disposition. Although not every allocation of limited resources should qualify for abstention, the presence of such class-wide impacts may provide a fair basis for abstention. The same can be said of ordering local government on the basis of state law to undertake structural reform or other affirmative governmental action that inay be difficult to undo in the event that the federal court should err. ${ }^{237}$ Of

236. For these very reasons, state courts that first obtain possession of a res inay issue injunctive relief even against federal courts. See Princess Lida v. Thompson, 305 U.S. 456, $465-68$ (1939). And, consistent with the anti-injunction statute, federal courts may issue similar injunctions to state courts when federal courts first obtain possession of property. See 28 U.S.C. § 2283 (1994) (allowing a federal court to enjoin ongoing state court proceedings "in aid of jurisdiction"); see also Kline v. Burke Constr. Co., 260 U.S. 226, 229-30 (1922) (noting in rem exception to anti-injunction statute). Because of the way in which any permit to drill arguably affected other property owners subject to the regulatory scheme at issue in Burford, soine have viewed the decision as involving a "limited pool" problem concerning which a state system first obtaining jurisdiction should be deferred to. See Rehnquist, supra note 2, at 1077-78; Treat, supra note 2, at 998. In Burford itself, two of the Justices in the five-person majority concurred separately to note that the decision was merely "an application of the principle expressed in" Pennsylvania v. Williams, 294 U.S. 176, 185 (1935), in which the Court upheld abstention to allow for a state's liquidation of an insolvent building and loan association. See Burford v. Sun Oil Co., 319 U.S. 315, 334-35 (1943) (Douglas and Murphy, JJ., concurring); $c f$. Colorado River Water Conservation Dist. v. United States, 424 U.S. 800, 819 (1976) (noting that the policy of the 1952 McCarran Amendinent, 43 U.S.C. $\$ 666$ (1994), which allowed the United States to be made a party to state court water-rights litigation, was based on concerns "akin to" the in-rein scenario).

In Colorado River the Court upheld federal court abstention as to water-rights claims brought by the United States when there was a pending parallel dispute in state court to which the Uirited States was a party. Abstention was not based on Burford, however, even though the state had set up an "elaborate procedure" for resolving conflicting claims before state "water judges" assigued to various in-state water districts. The Court simply stated that the existence of federal claims, which might result in conflicting adjudications, would not "impair impermissibly the State's effort to effect its policy respecting the allocation of state waters." Colorado River, 424 U.S. at 816. See generally Linda Mullenix, A Branch Too Far: Pruning the Abstention Doctrine, 75 GEo. L.J. 99, 107-09 (1986) (critiquing the Court's justification for abstention in Colorado River).

237. For example, if a diversity case involved the question whether a municipality could issue bonds as a matter of state law, there might be an argument for abstention under this approach if the question was raised in anticipation of the issuance, as opposed to after the fact. In advance of issuance, it is the state that should be able to create the broad-reaching reliance interests, which a federal court (if diversity were present) ought to be able to enforce after the fact. But $c f$. Meredith v. 
course, the abstention possibilities suggested here are ones that are not exclusive to agency action, ${ }^{238}$ but are applicable to any local governmental action raising similar sorts of questions in the context of an ongoing regulatory regime. ${ }^{239}$

\section{Risks of Error and the Federal Forum}

Once it is recognized that judgnient-nuade law operates priniarily between the parties, and that it is appropriate for the federal courts to engage in some such interstitial lawnraking, it becomes apparent that some nonuniformity in outconies between state and federal courts is

Winter Haven, 320 U.S. 228, 236-38 (1943) (denying abstention in a diversity case brought in advance of issuance).

In each of these contexts, we beheve that abstention (or certification) can play an important but more limited role given the special risk to state interests from federal court intervention, above and beyond the ordinary risks of interference that come with the exercise of jurisdiction on judicial review of agency action.

238. At the Court's definitional level Burford is sometimes said to consist of two priuciples, the first of which is taken from Thibodaux, and only the second of which is specific to administrative agencies. Thus, in New Orleans Public Service, Inc. v. Council of the City of New Orleans the Court described the "Burford doctrine" as including two propositions:

Where timely and adequate state-court review is available, a federal court sitting in equity must decline to interfere with the proceedings or orders of state administrative agencies: (1) when there are "difficult questions of state law beuring on policy problems of substantial pubhic import whose importance transcends the result in the case then at bar;" or (2) where the "exercise of federal review of the question im a case and in similar cases would be disruptive of state efforts to establish a coherent pohey with respect to a matter of substantial public concern."

491 U.S. 350, 361 (1989) (quoting Colorado River, 424 U.S. at 814, in giving this two-prong formulation). Colorado River in turn cites Thibodaux for the first prong and Burford for the second.

Perhaps the first of these primciples may be the more overarching and compelling of the two. See also Young, supra note 2, at 911, 942 (noting that Burford might better be scen as a subset of Thibodaux, rather than the other way around). The Thibodaux component of Burford was emphasized in Ankenbrandt v. Richards, 504 U.S. 689, 705 (1992), in which the Court stated that "[i]t is not inconceivable... that ... the abstention principles developed in [Burford] might be relevant" in domestic relationship cases that would not (as would suits for divorce, alimony or child custody) be jurisdictionally barred from the federal courts. See Rehnquist, supra note 2, at 1075-82.

239. The Supreme Court scems generally reluctant to construe provisions of state constitutions relating to resource allocation. See, e.g., Kaiser Steel Corp. v. W.S. Ranch Co., 391 U.S. 593 (1968) (per curiam) (holding that an unclear question of state law regarding whether defendant's extraction of water from plaintiff's land was for "public use" under the state constitution warranted abstcntion); see also Reetz v. Bozanich, 397 U.S. 82 (1970) (holding that unclear questions concerning state constitutional provisions relating to "common use" of "fish resources" warranted abstention). By contrast, possible unclear questions arising from individual rights provisions in state constitutions that mirrored federal provisions have usually bcen insufficient for abstention on Pullman grounds. See, e.g., Examining Bd. of Eng'rs, Architects and Surveyors v. Flores de Otcro, 426 U.S. 572, 598 (1976) (declining to abstain to permit a Puerto Rico commonwealth court to decide whether the challenged provision violated the Puerto Rico Constitution's equal protection provisions); Wisconsin v. Constantineau, 400 U.S. 433, 437-39 (1971) (rejecting abstention); id. at 440 \& n.1 (Burger, C.J., dissenting) (arguing for abstention to give the state court the opportumity to invalidate a statute under the state's equivalent of the Due Process Clause); cf. Askew v. Hargrave, 401 U.S. 476 (1971) (remanding a federal constitutional challenge to the state's school-funding scheme for consideration of abstention when a pending state court proceeding was addressing a similar challenge under the state constitution). 
unavoidable. Any time a federal court ventures to interpret or apply state law, it may turn out to be "wrong" as revealed by later state-court decision making. But nonuniformity probleins are common in litigation generally, and may be a necessary side-effect of individualized justice. And, of course, nonuniformity is endemic to a federal system in which Congress has enlisted the federal courts in the administration of state law (and state courts in the administration of federal law). ${ }^{240}$ The inore relevant question, therefore, is how the costs of possible nonuniformity compare to the costs associated with any effort to secure a more "accurate" assessment of state law froin the state system. Among the latter costs must be counted the loss of a diversity forum to out-ofstaters for the resolution of disputed issues-not only issues of fact, but issues of state law as well. ${ }^{241}$

When federal and state court outcomes in state-law litigation appear to diverge, there is of course a risk that similar cases are not being treated alike. Parties may also feel that out-of-staters receive advantages that in-staters do not. ${ }^{242}$ But the disadvantages of nonumiformity caused by having an imitial federal decision-even on an undecided issue of state law - inust be weighed against the supposed advantages of diversity jurisdiction. Diversity jurisdiction reenains a congressionally chosen vehicle for protecting out-of-staters from possible unfairness that might be difficult to police on direct review froin state courts. ${ }^{243}$ The risk of parochial justice in state courts (whether real or perceived) can manifest itself not only with respect to questions of fact, but with respect to questions of law and law application as well. ${ }^{244}$ Indeed, this may be especially true when out-of-state parties are at odds with a state agency ${ }^{245}$ Prior to Erie, federal courts zealously-perhaps overzealously-guarded against such bias by providing non-residents with a surrogate due process through their application of general law in the exercise of diversity jurisdiction. Even under Erie's command to follow rather than ignore state law, allowing federal courts to articulate and apply state law in diversity cases still serves an important function.

240. See Wells, supra note 227, at 97-106 (discussing inevitable trade-offs in traditional federal courts law, including loss of uniformity in a federal systein); $c f$. Testa v. Katt, 330 U.S. 386 (1947) (imposing a duty of jurisdictional nondiscrimination on state courts).

241. See Gowen \& Izlar, supra note 225 , at 213 (stating that diversity entails a statutory right to have issues of fact and state law determined by a federal court).

242. One of Erie's aims, of course, was to prevent "discrimination" in the treatunent of in-staters vis-à-vis out-of-staters. See Erie R.R. v. Tompkins, 304 U.S. 64,74 (1938).

243. See Friedman, supra note 2, at 540-41 (noting the premise of diversity that out-of-state hitigants may be subjected to bias, and its conflict with the premise of abstention that state courts are adequate to protect rights).

244. See Treat, supra note 2, at 994-96 (discussing incentives and disincentives to nonprejudicial state court interpretation of state law when nonresidents are involved).

245. See infra text accompanying notes 257-258. 


\section{a. Diversity Jurisdiction When State Law Is Settled}

Where state law is settled, federal courts should have little difficulty in faithfully answering any state-law questions and applying state law to disputed facts. Any difference in outcomes between state and federal courts in such cases would be the inescapable and perhaps not undesirable result of diversity jurisdiction. Such variation of results could exist even in a unified, nonfederal judicial system.

It is still arguable, of course, that federal courts ought to abstain even when state law seems settled. ${ }^{246}$ After all, state courts can change their minds and develop a new common-law rule or reinterpret state positive law. And even when the substance of the law is clear, application to different facts can also make new law. A federal court that rules on the basis of apparently clear state law may not be able to anticipate such a change. In such circuinstances, there might be nonuniformity between how a federal court would decide the case and how a state court would. But even under the Court's current approach to such matters, it is unlikely that abstention would be ordered unless impending legal change was visible on the horizon. ${ }^{247}$ Abstention even when state law appears settled would make diversity jurisdiction a non-starter, because the threat of nonuniformity would command abstention in virtually every case.

246. This appears to be the perspective of Professor Bradford Clark. See Clark, supra note 2. His broad-ranging treatment of the role of federal courts in the articulation of state law purports to address the problem of federal court decisions on state law-and to recommend certification-only when state law is "unclear" or "indeterminate." See, e.g., id. at 1465, 1549, 1552, 1564. Yet he also seems to find it troublesome for federal courts to apply even apparently settled state law because federal courts might miss some novel development im state law that would have occurred had the case been litigated $\mathrm{im}$ the state courts. See $i d$. at 1464-65, 1541-42. Thus, he ultimately rejects as mconsistent with judicial federalism principles embodied in Erie, even a "static model" in which federal diversity courts would apply state law as it apparently is, rather than trying to predict its course (under a "predictive model" that he also rejects). See id. at 1541-42. But if a federal court's missing out on a potential change in state law presents a problem for him, then he is very close to arguing that federal courts ought to decline, via certification, to decide seemingly clear state-law issues as well. (Our doubts as to whether certification eliminates the problems that we associate with abstention are set forth infra in the text accompanying notes 256-258.) It is said to be "unresolved" whether Burford-type abstention might apply even when state law is clear. See CHEMERINSKY, supra note $5, \S 12.2 .3$, at $755-56 \mathrm{n}$. 91; $c f$. Field, supra note 2, at 1153-54 (suggesting that Burford might apply in such settings).

247. See Meredith v. Winter Haven, 320 U.S. 228, 237 (1943) (overturning dismissal granted in a diversity case merely because state law was unclear, and noting that Erie "did not free the federal courts from the duty of deciding questions of state law in diversity cases"). Even in the context of Pullman abstention, the Court generally requires more than a showing that state law is "'of an uncertain nature""; it must also be "'obviously susceptible of a limiting construction." Hawaii Hous. Auth. v. Midkiff, 467 U.S. 229, 237 (1984) (quoting Zwickler v. Koota, 389 U.S. 241, 251 \& n.14 (I967)). But $c f$. Arizonans for Official English v. Arizona, 117 S. Ct. 1055, I073-74 (1997) (suggesting in dictum that certification might be proper in a Pullman setting if state law was "susceptible" of a limiting construction (citing Bellotti v. Baird, 428 U.S. 132, 148 (1976))); CLINTON ET AL., supra note 94, at 1243 (noting occasional expressions of a lower threshold of uncertainty of state law for purposes of certification). 
A possible reason for not abstaining when state law is clear may be that the risk of error is small in such cases, ${ }^{248}$ and that the parties' inconvenience and judicial expense associated with halting the federal action and shuttling some or all of it to the state courts is large. But a better reason for not abstaining may be that the federal diversity courts exist to protect against novel interpretations or applications of state law at the expense of non-residents. Although state legislation that discriminates against out-of-staters may be relatively easy to spot, other forms of discrimination that can arise im judicial and jury decision making may not be. If there is no reason to suppose that state courts will play fast and loose with their own law when non-residents are involved, then perhaps there is no reason to suppose that they would do so with mere factfinding either. ${ }^{249} \mathrm{But}$ the argument proves too much; assuming that there is no such thing as hoine-town justice would ultimately leave no room for the exercise of diversity jurisdiction. In this narrow respect, therefore, federal diversity courts today should still heed the old Court's admonition to protect out-of-staters against sudden changes im settled state law, ${ }^{250}$ as well as provide a neutral factfinder.

\section{b. Diversity Jurisdiction When State Law Is Unsettled}

Where, by contrast, state law is not well settled, the states' interests in giving initial shape to their law is certainly greater. But this imterest does not diminish the possibility of bias against out-of-staters that diversity jurisdiction presupposes. Indeed, the risk of bias against a nonresident in the interpretation of untested state law may be even greater than in cases of routine law application to disputed facts. ${ }^{251}$ In these circumstances, the federal courts can provide laboratory conditions for the articulation and application of unsettled state law (at least in the absence of class-wide collateral fallout, as discussed above). Perhaps for these

248. See Field, supra note 2, at 1093 (using the likelihood of error as a factor in assessing the propriety of abstention).

249. In reality, the greater prejudice to out-of-staters would appear to come from the bench, on questions of law, than on questions of fact-finding from the jury, as we argue below. See infra text accompanying notes $251,256-258$.

250. That, of course, was the ostensible purpose of Gelpcke v. City of Dubuque, 68 U.S. (1 Wall.) 175 (1863). See supra text accompanying notes 27-38; cf. Daniel J. Meltzer, State Court Forfeitures of Federal Rights, 99 HARv. L. REv. 1128, 1137-43 (1986) (noting that novel state court interpretations of state law might not provide adequate state grounds to bar direct review of federal questions).

251. Professor David Currie got it exactly right when he noted that "the obscurity of state law furnishes a unique opportumity for undetectable implementation of bias." Currie, supra note 2, at 314. As we have discussed, however, some questions regarding the allocation of state power may be presented in settings that call for abstention. See supra text accompanying notcs 234-239. 
very reasons, in the non-administrative context, abstention has never been routinely allowed simply because state law is unclear. ${ }^{252}$

Moreover, federal courts' decisions on unsettled questions of state law may occasionally help state courts that later attempt to decide the same issues in litigation between co-citizens. ${ }^{253}$ State courts might find the federal court's reasoning persuasive, in which case there would be no nonuniformity. And if the state courts disagreed, there would at least be confidence that their decision of law was not based on biases against out-of-staters.

By contrast, in cases involving litigation between co-citizens (e.g., through pendent jurisdiction as in Pullman), it may make more sense to send novel state-law questions to state court, because such cases lack the concern that bias against non-residents might skew the determination of state law. ${ }^{254}$ Similarly, if abstention is proper for issues of class-wide import, the risk of bias against out-of-staters is minimized because of the wide-ranging effects of a judgment im which im-state imterests may make up part of the relevant class.

It might be argued that the risk of prejudice to out-of-staters by a state court decision on a question of state law diminishes as the generality of the question of unclear state law increases, ${ }^{255}$ and that abstention therefore should be unproblematic in such settings. After all, if the rule of new law in a particular case might have to be applied in subsequent cases to im-staters and out-of-staters alike, a state court will arguably be less able to "get away with" a construction of state law that adversely impacts non-citizens. And if the unclear state-law question can be

252. See Meredith v. Winter Haven, 320 U.S. 228, 234 (1943); see also Wright, supra note 2, at 826-27 (stating that diversity wonld effectively be abolished were there to be wholesale abdication from deciding unclear questions of state law).

253. See David L. Shapiro, Federal Diversity Jurisdiction: A Survey and a Proposal, 91 HARv. L. REv. 317, 325-26 (1977); see also POSNER, supra note 234, at 216 (accepting the creative function of federal courts when state law is unclear). While some have questioned the notion that state courts would find it helpful for state-law questions to percolate through another system, see Clark, supra note 2, at 1562-63, administrative law, at least, is an area where the fcderal courts have a nore developed body of jurisprudence than state courts. See Pieter M. Schenkkan, When and How Should Texas Courts Review Agency Rules?, 47 BAYLOR L. REV. 989, 999 (1995) (indicating that Texas standards of review were still a subject of debate, and suggesting that the state courts could learn from analogous federal experience). Of course, there is still the objection that this sort of federalcourts-know-best intermeddling is exactly what Erie meant to eradicate, see Clark, supra note 2, at 1563 , but the "helpfulness" discussed in the text is not so much a reason for not abstaining as a potentially beneficial rcsult of not abstaining.

254. Pullman abstention, too, should therefore be harder to justify when diversity is also a basis for federal court jurisdiction. See Treat, supra note 2, at 989 \& n.104. Even in the usual Pullman setting, the Court usually insists that state law be substantially unclear. See supra note 247. In addition, to the extent that the supplemental jurisdiction statute, 28 U.S.C. $\S 1367$ (1994), is operative, separation-of-powers concerns ordmarily associated with judge-made abstention are absent. The latter statute specifically allows for jettisoning supplemental state-law contests when they present "novel" questions of state law. Id. § 1367(c).

255. See BREYER ET AL., supra note 185, at 33. 
promptly certified to a state court of last resort whose pronouncements will have broad effect in other courts, the risk is arguably even further diminished. As some scholars have noted, certification means that the federal diversity court loses only its state-law norm-articulation function, and retains the remaining incidents of the jurisdiction, including factfinding and law-application. ${ }^{256}$ Certification is therefore less imtrusive than outright abstention with dismissal.

Perhaps the high level of generality of an unclear state-law question and the higher level of the deciding court can act as partial safeguards against the risk of state court abuse in agency review cases involving out-of-staters. Indeed, we have acknowledged that the generality of the application of a particular state-law question may present circuunstances for federal court abstention in unusual settings. But given the limited impact of judgment-made law in the diversity setting, and the obviousness of who would stand immediately to benefit from the state-court ruling on unclear state law, those safeguards are imperfect substitutes for the categorical safeguard that diversity affords. As we have argued, bias can manifest itself in any aspect of judicial decision inaking, including the formulation of new rules of law in cases in which out-of-staters are the imitial subjects. Although a primary source of discrimination against out-of-staters in the typical diversity action is thought to be the statecourt jury, ${ }^{257}$ the risk of bias does not disappear when politically accountable state judges address questions of state law..$^{258}$

As a consequence, there remains a risk that state judiciaries will overvindicate the interests of local government (and other in-staters) at the expense of non-citizens. Protection against such possibilities was a legitimate concern of the nineteenth-century federal courts just as it is today, even if the particular inanner in which those courts secured that right was the illegitimate developinent of general law. In the era of Swift, federal courts inay have assumed an improper role in the independent development of state law. But Erie did not withdraw froin federal courts the function of faithfully deciding the ineaning of state law when diversity jurisdiction is present.

256. See Clark, supra note 2, at 1549-56; see also supra note 233 (critiquing liberal use of certification for questions of unclear state law).

257. In the actions for judicial review of agency action on which we lave focused, there presumably would be no juries to contend with, only judges.

258. In fact, the risk of bias from state judges who review agency action may be greater than that typically associated with juries in actions at law, whose members would be drawn from within the state whether litigation went forward in state or federal court. See Wells, supra note 227, at 109 (noting, in connection with federal question litigation, that state judges' "backgrounds may lead them to give greater weight to the state's regulatory interests"). 


\section{c. State Agency and State Court Inconsistency}

Finally, one might argue that even the application of fairly wellcrystallized state legal standards can sometimes be too subtle for the federal courts. That was an apparent concern of the Court in Burford, where state courts had experience with the particular issues involved, but the course of administrative decisions had been uneven. ${ }^{259}$ Such agency inconsistency, however, is no stranger to the federal courts. The failure of a federal agency to follow its own precedents, while tolerable, generally requires an adequate agency explanation minimally to guarantee against arbitrariness. ${ }^{260}$ Under the presumptive deference standards that we have suggested federal courts would apply to state administrative action, federal courts could normally be expected to show at least equal tolerance to swings in state policy, unless state law itself directed a different result. If, however, the state courts have inconsistently deterinined a particular issue without adequate explanation, there may be little reason for the federal courts to fear inconsistency by exercising jurisdiction.

Some federal courts scholars see the wavering of state agencies and state courts in a different light, and as warranting abstention in deference to the state institutions' too-subtle-to-be-imitated atteinpts to craft a "coherent" policy. ${ }^{261}$ But in cases of state agency and state court wavering, the chances for unfairness to outsiders are maximized while the chances for any substantial inconsistency of a federal decision with a state court decision are minimized. A federal court decision could also have the advantage of attempting to find a pattern to state doctrine, or of finding it utterly incoherent. A refusal of federal courts to exercise jurisdiction when state doctrine is incoherent, however, would amount to little more than deference to state anomie.

$$
* * *
$$

The rationales for federal courts' avoiding review of state agency action challenged on state law grounds are less than compelling. Deferential review involves federal courts less in "policy making" than does

259. See Burford v. Sun Oil Co., 319 U.S. 315, 327 (1943).

260. See Atchison, Topeka \& Santa Fe Ry. v. Wichita Bd. of Trade, 412 U.S. 800, 807-09 (1973) (indicating that agency action is arbitrary and capricious if it represents an unexplained departure from prior policy).

261. See Field, supra note 2, at 1157 (considering the argument that factual complexity as in Burford might mean that subtle variations in application of a consistently stated standard is possible, rendering results of individual cases uncertain although state law is clear); see also Young, supra note 2, at 909, 963 (seeing Burford as involving "unacceptable risk of error" on issues involving state law and its application). But cf. Federal Power Comm'n v. Hope Natural Gas Co., 320 U.S. 591, 627 (1944) (Frankfurter, J., dissenting) (noting that expertise is a rational process implying cxpress reasons for judgment). 
de novo review, and such review is not inherently "appellate." Thus it makes sense to continue to regard judicial review of state agency action as a judicial function that is distinct from agency process and proper for federal courts. Nor should federal courts shy away from state administrative review on the ground that they may decide undecided issues of state law differently from how state courts would decide them. Rather, undecided issues of state law can present opportumities for bias against out-of-staters for which diversity is the constitutionally and statutorily provided antidote. Abstention is called for only in cases imvolving classwide or similar impacts, where the likelihood of bias against out-ofstaters is minimized and an inclusive federal judgment would foreclose later state court development of state policy.

\section{IV}

\section{Federal-Law Challenges to State Agency Action IN THE FEDERAL COURTS}

The principles of federal court nomintervention and abstention associated with Burford and related decisions are applicable in challenges to state agency action based on federal law as well as state law. Nevertheless, the gravitational pull of $\S 1983^{262}$ competes with these principles in a wide variety of federal question cases. ${ }^{263}$ Indeed, federal challenges to completed state agency action, particularly those implicating heightened judicial scrutiny, tend to be treated like any other $\S 1983$ action. As such, subject to limitations common to all such litigation, they often command a federal forum without regard to available state process.

In practice, Burford has most significantly affected federal due process challenges to the rationality of state agency action. ${ }^{264}$ That administrative abstention should hold greater sway in the area of reasonableness challenges rather than fundamental rights challenges is consistent with its origins in the marginalization of economic due process and the refocus of modern constitutional litigation on fundamental

262. Section 1983's modern development took place well after Burford, beginning with Monroe v. Pape, 365 U.S. 167 (1961), overruled in part on other grounds by Monell v. Department of Soc. Servs., 436 U.S. 658 (1978). Both before and for some time after Monroe, $\S 1983$ did not reach constitutional claims involving denials of property interests, at issue in Burford, as distinguished from hiberty interests. See supra note 152 and accompanying text.

263. Scction 1983 provides a remedy for state or local officials' violations of many federal statutory as well as most constitutional norms. See Maine v. Thiboutot, 448 U.S. 1, 4 (1980).

264. See, e.g., Wells, supra note 2, at 77; see also Young, supra note 2, at 903-04, 923-24, 932 n. 400 (suggesting that there might have to be a "greater showimg of need" for use of Burford in federal question as opposed to diversity cases, especially when a "non-economic constitutional right" is at issue); $c f$. Colorado River Water Conservation Dist. v. United States, 424 U.S. 800, 815 n.2I (1976) ("[T]he presence of a federal basis for jurisdiction may raise the level of justification needed for abstention."). It is sometimes said that the presence of federal questions will "weigh against" certain kinds of abstention. See Moses H. Cone Mem'l Hosp. v. Mercury Constr. Corp., 460 U.S. 1, 26 (1983). 
rights. But the Supreme Court has continued to suggest that nonintervention principles would not be limited to such settings, ${ }^{265}$ and lower federal courts have found them applicable to a variety of federal statutory and constitutional challenges to state agency action. ${ }^{266}$ Clearer delineation of which federal-law issues arising from state administrative action ought to reviewable under the rubric of general federal question jurisdiction is therefore in order.

In this Part we examine the proper scope of these nonintervention principles as applied to federal-law challenges to state administrative action. First, we consider $\S 1983$ actions raising due process challenges to the reasonableness of agency action in light of the changed focus of modern constitutional law and related concerns underlying administrative abstention that federal courts should not routinely displace ordinary state administrative review. We then consider whether $\S 1983$ or other federal actions that implicate heightened judicial scrutiny or challenges to systemic illegality should nevertheless be subject to abstention based on the complexity of the regulatory scheme or the concentration of judicial review in a single forum. ${ }^{267}$ Fimally, we briefly discuss the role of preclusion as applied to judicial-style agency decision making and its relation to the Court's other agency-noninterference doctrines.

\section{A. Challenges Implicating Administrative Unreasonableness}

\section{Ad Hoc Denials of Nonfundamental Rights}

In contrast to challenges to state agency action implicating Bill of Rights or other fundamental rights violations, claims that an agency has acted unreasonably or arbitrarily in an individual case are problematic candidates for the federal courts. Too broad a recognition of federal substantive due process claims would routinely create federal issues out of the misapplication of state law by state officials, and would run the risk of wiping out any meaningful distinction between state and federal law. ${ }^{268}$ Although we have argued that federal courts can and should

265. See New Orleans Pub. Serv., Inc. v. Council of City of New Orleans, 491 U.S. 350, 367 (1989).

266. For lower court invocation of these sorts of considerations, see Davies, supra note 2, at 4345; Treat, supra note 2, at 980-89; Young, supra note 2, at 900-06 (noting, however, that many courts are reluctant to abstain in certain constitutional cases implicating heightened scrutiny, such as First Amendment claims and claims of federal preemption); see also cases cited infra note 300.

267. The Court has mentioned these considerations when federal-law challenges to state agency aetion were involved, but they would also be relevant in state-law challenges. We consider these concerns, briefly, in both settings. See infra text accompanying notes 301-315.

268. See generally Rodney A. Smolla, The Displacement of Federal Due Process Claims by State Tort Remedies: Parratt v. Taylor and Logan v. Zimmerman Brush Company, 1982 U. ILL. L. Rev. 831,867 (concluding that $\S 1983$ and the Due Process Clause often would not improve on the welltailored balances of common-law protections for traditional common-law interests); see also Michael Wells \& Thomas A. Eaton, Substantive Due Process and the Scope of Constitutional Torts, 18 GA. L. 
entertain such ad hoc agency review claims (as state-law claims) in the context of diversity, that does not nean that they should be able to find their way into federal court as federal claims under federal question jurisdiction. Otherwise, all such claims could easily be recast as constitutional actions and find their way into federal court, even absent diversity and the risk of prejudice to out-of-staters. ${ }^{269}$

The problem of over-federalization of state administrative law arises because due process arbitrariness challenges - at least on their surface-seein to overlap with normal state-law statutory review standards for state agency review. Such state-law standards allow agency action to be challenged on the ground that it is unreasonable, arbitrary and capricious, and beyond statutory authority. ${ }^{270}$ Such state-law "administrative unreasonableness" claims, however, are not as difficult to make out as are viable federal due process reasonableness claims, despite the verbal overlap. State-law administrative unreasonableness claims, for example, require only a showing of simple failure to follow statutory standards, action beyond statutory authority, or failure to consider relevant criteria. By contrast, federal due process claims in the legislative or rulemaking context require a showing that the legislation lacks a conceivable rational basis, ${ }^{271}$ while ad hoc agency action (such as the denial of a permit or license) appears to require a strong showing of arbitrariness, if not conscience-shocking behavior. ${ }^{272}$

REv. 201, 212 (1984) (stating that the danger of constitutional tort theory taking over matters best left to the common law is greater when the claim asserts a general injury to life, liberty or property than when a more specific constitutional right is at issue).

269. Even at the heiglt of economic substantive due process relatively few claims alleging ad hoc agency illegality were the subject of federal question actions, perhaps because it was long unclear when ad hoc deprivations that may also have been in violation of state law implicated "state action" for purposes of the Fourteenth Amendment. See, e.g., City of Meinphis v. Cumberland Tel. \& Tel. Co., 218 U.S. 624, 632 (1910) (a local regulatory ordinance entered "without authority of the State" could not contravene the Fourteenth Amendment); Bamey v. City of Ncw York, 193 U.S. 430 (1904) (a violation of state law by itself could not violate the Fourteenth Amendment); $c f$. Yick Wo v. Hopkins, 118 U.S. 356 (1886) (systemic racial discrimination by local licensing officials pursuant to a statute granting broad discretion violated the Fourteenth Amendment). Even when the Court declared in Home Telephone \& Telegraph Co. v. City of Los Angeles, 227 U.S. 278 (1913), that state action might be found even when state law was violated, it did so in a case in which a local governmental entity had engaged in the clearly legislative action of rate-setting.

270. See generally McGrath et al., supra note 183, at 719-31 (discussing various standards of review for state administrative action in state courts).

271. See County of Sacramento v. Lewis, 118 S. Ct. 1708, 1716 (1998) (stating that criteria to identify what is fatally arbitrary differ depending on whether a legislative or specific act of a government officer is at issue).

272. The Court has stated that ad hoc executive illegality that is challenged as "arbitrary," but that does not implicate fundamental rights, will state a claim for relief under $\$ 1983$ only when it rises to a sufficiently egregious level of arbitrariness that it "shocks the conscience," Lewis, $118 \mathrm{~S}$. Ct. at 1716 ("Our cases dealing with abusive executive action have repeatedly emphasized that only the most egregious official conduct can be said to be 'arbitrary in the constitutional sense' ...." (quoting Collins v. Harker Heights, 503 U.S. 115, 129 (1992))); or, in some circumstances, on a lesser showing of "deliberate indifference," City of Revere v. Massachusetts Gen. Hosp., 463 U.S. 239, 244 (1983) 
The high barrier confronting federal due process challenges to ad hoc agency action means that many such claims may fail to present substantial federal questions, and therefore will be jurisdictionally barred. Given the imprecise contours of substantive due process and the possibilities of creative pleading, however, it may be uncertain in some cases whether an adequate federal claim has been stated. ${ }^{273}$ Thus, it might be preferable to treat such claims as generally appropriate for abstention rather than as necessarily lacking a substantial federal question (unless there is an allegation of especially egregious behavior).

Our recommended scope for administrative abstention in this context bears some resemblance to the Supreme Court's treatment of similar issues in Parratt v. Taylor ${ }^{274}$ and its offspring. Those decisions indicate that although a state may be required to provide a fair system of compensation for some traditional tortious deprivations committed by public officials, such mjuries do not usually state a viable claim for relief in federal court under $\S 1983$. There are important similarities between tort due process under Parratt and due process claims that a state agency has misapplied state law or has applied it unreasonably. Both may involve deprivations of traditional common-law interests for which due process inay actually provide some remedial baseline. That baseline, moreover, is not merely procedural, but may be substantive as well. For example, the Due Process Clause inay require states to provide refunds of unlawfully assessed taxes, to allow rates that will insure a fair return on capital, and to provide compensation for certain intentional torts by its officers. ${ }^{275}$ The level of federal due process protection, however, is slight in such cases when compared to specific Bill of Rights guarantees and other areas implicating heightened scrutiny, most of which typically command a federal trial court forum, Parratt notwithstanding. ${ }^{276}$

(involving medical needs of pre-trial detainees). We would include ad hoc claims of unequal treatment that did not implicate constitutionally impermissible motivation within this category of "administrative unreasonableness" claims that federal courts should avoid.

273. The Court has avoided imposing heightened pleading requirements on $\S 1983$ plaintiffs. See Crawford-El v. Britton, 118 S. Ct. 1584, 1595 (1998) (concluding that heightened pleading was not required of a $\$ 1983$ plaintiff alleging a constitutional claim involving inproper motive); Leatherman v. Tarrant County Narcotics Intelligence and Coordination Unit, 507 U.S. 163, 168 (1993) (concluding that heightened pleading was not required in a $\$ 1983$ action involving a local governmental custoin or policy).

274. 451 U.S. 527 (1981), overruled in part on other grounds by Daniels v. Williains, 474 U.S. 344 (1986).

275. See Richard H. Fallon, Jr., Some Confusions About Due Process, Judicial Review, and Constitutional Remedies, 93 Colum. L. Rev. 309, 311 (1993) (suggesting that Parratt may imply that the state is required to maintain a systen of adequate remedies for violations of nonfundamental rights).

276. Because of the phrasing of the Takings Clause, U.S. CoNST. ainend. V-that private property not be "taken for public use, without just compensation"-federal court intervention must 
To be sure, agency decision making-even nonsystemic ad hoc decision making that runs afoul of state law-does not resemble exactly the tort-like behavior of individual officers that Parratt sought to remove from the scrutiny of the lower federal courts under the aegis of $\S 1983$ and federal question jurisdiction. Such agency decision making can seem more deliberate ${ }^{277}$ and collegial, and less "random and un authorized"278 than the ad hoc tortious behavior of the individual officer. In addition, although agency action may violate state law, the action may look less like a traditional tort than the random and unauthorized deprivations of property or liberty characteristic of Parratt and its progeny.

But the similarities to Parratt in these circumstances are still considerable, even when an agency and not an officer is the wrongdoer. The agency action to which our administrative abstention principle would apply is by hypothesis non-legislative and nonrecurrent. Fundamental rights are by definition not at issue, and state court review of state-law questions is available. As with Parratt itself, the federal interest in having such cases heard in federal trial courts (even under weak rationality review) is substantially less than in other contexts, especially that of fundamental rights. And, as in Parratt, the state imterest in preserving the integrity of its public law, particularly in litigation mvolving in-state citizens, is substantial. Thus, even if it expands upon Parratt somewhat ${ }^{279}$ to keep such claims of ad hoc agency unreasonableness out

ordinarily await not only a final taking, but efforts at compensation from the state system as well, before the constitutional violation will be "complete." See Williamson County Reg'l Planning Comm'n v. Hamilton Bank, 473 U.S. 172, 194-96 nn.13-14 (1985). If there has been a final taking-for example, as a result of completed state or local agency action-and no system of state compensation is available, the takings claim may be ripe for federal district court consideration in an action under $\S 1983$ at the conclusion of such agency action. See Suitum v. Tahoe Reg'l Planning Agency, 117 S. Ct. 1659 (1997). But until there has been a final taking (which may itself require resort to available post-agency state judicial proceedimgs for waivers, variances, and the like), plus resolution of the issue of compensation (if a mechanism for resolution is available), a federal forum is not available. If compensation proceedings have been tried out in the state system, perhaps only direct Supreme Court review will be available thereafter. $C f$. Rehnquist, supra note 2, at 1100-01 (suggesting that the confiscation claim in Burford would not be ripe for review in the federal courts under Williamson). Nevertheless, some scholars would find abstention to be appropriate in most land use settings. See, e.g., Ryckman, supra note 2, at 440 .

277. See County of Sacramento v. Lewis, 118 S. Ct. 1708, 1720 n.13 (1998) (suggesting that lower standards of hability may apply for more deliberate behavior).

278. Under Parratt, if the deprivation of nonfundamental liberty and property interests is not random and unauthorized, it will not escape federal trial court scrutiny. See Logan v. Zimmerman Brush Co., 455 U.S. 422,435 (1982). A similar inquiry is imposed for ascertaining local entity hability when a state or local officer has violated federal law or the Constitution. See Monell v. Department of Soc. Servs., 436 U.S. 658, 690-95 (1978).

279. Such an approach would not expand Burford, however, and it is not as though federal courts have been hospitable to such cases; if anything, the opposite seems true. See supra note 264 (and authorities discussed therein); see also Quackenbush v. Allstate Ins. Co., 517 U.S. 706, 723 (1996) (seeing the maim issue in Burford as "reasonableness" of a particular commission order). In addition, 
of the lower federal courts (absent diversity), the allocation of judicial responsibilities makes sense. As with other claims subject to Parratt, unless the degree of unreasonableness is alleged to rise to a particularly egregious level of arbitrariness, such claims of agency unreasonableness should probably be rerouted to state court.

\section{Systemic Denials and Legislation}

If the analogy to Parratt is correct, a claim that an agency has engaged in a systemic (rather than merely ad hoc) denial of federal due process could well deserve a federal trial forum. ${ }^{280}$ Unlike claims of ad hoc illegality, it is less likely that systemic illegality claims will broadly displace state law, and they may suggest greater deliberation and fault on the part of state officials. ${ }^{281}$ But an expansive reading of the Court's administrative abstention decisions could bar even systemic challenges to the reasonableness of agency action from the federal courts; indeed, Burford itself may have involved a challenge to systemic agency discrimination. ${ }^{282}$ To the extent that Burford embodies a judge-made extension of the Tax and Rate Injunction Acts, it would by analogy to those statutes encompass even systemic challenges. ${ }^{283}$ If so, then

the federal claim in such administrative reasonableness challenges may, as in Burford itself, be heavily dependent on the construction of state law and the apphication of state law to disputed facts. Perhaps this is what the Court is getting at when it talks about problems supposed to be associated with resolving questions of federal law that are "entangled in a skein of state law that must be untangled before the federal case can proceed." Quackenbush, 517 U.S. at 727 (quoting New Orleans Pub. Serv., Inc. v. Council of City of New Orleans, 491 U.S. 350, 361 (1989)); cf. District of Columbia Court of Appeals v. Feldman, 460 U.S. 462, 486 (1983) (noting that due process allegations that a regulatory body acted arbitrarily and capriciously in denying a petition for waiver of a bar admission requirement were "inextricably imtertwined" with its deeision to deny the petition).

280. See Fallon, supra note 275, at 315-16, 329-39; see also Logan v. Zimmerman Brush Co., 455 U.S. 422 (1982) (addressimg a systein-caused deprivation of plaintiff's civil action).

281. To state the argument another way, under Parratt, the class-wide impact of the challenged illegality alleged to violate federal law creates a stronger claim to a federal forum than a claim of ad hoc illegality, whereas the class-wide impacts from a challenge to state action based on state law provides a reason for federal courts to hesitate before exercising jurisdiction.

282. See Sun Oil Co. v. Burford, 124 F.2d 467, 468 (5th Cir. 1942) (describing objections by larger traet owners to allowing Burford to drill four wells on a 2.33-acre tract), rev'd, 319 U.S. 315 (1943); see also Railroad Comm'n v. Rowan \& Nichols Oil Co., 311 U.S. 570, 572-73 (1941) (noting the argument as to illegalities in distributing production among different classes of producers).

283. The Supreme Court's imterpretations of the Tax and Rate Injunction Acts, 28 U.S.C. \$§ 1341-1342 (1994), and their penumbrae exclude most federal trial court challenges to statutes and many challenges even to the substantive inadequacy of remedies. See Fair Assessment im Real Estate Ass'n v. McNary, 454 U.S. 100 (1981) (noting that a suit for refund of taxes allegedly assessed in violation of federal law, as well as a clain that the state's refusal to pay interest on wrongful assessinents violated the Constitution, was an issue for the state courts and the Supreme Court on direct review). Because ratemaking is considered to be a legislative act, see Prentis v. Atlantic Coast Lime Co., 211 U.S. 210, 228 (1908), the primary effect of the rate mjunction statute is to exclude legislative action froin judicial review. Cf. Martin v. Creasy, 360 U.S. 219 (1959) (abstaining under Pullman in a case in which landowners had brought state and federal challenges to the lack of compensation to abutting landowners when access to a highway was limited). 
reasonableness challenges to agency rulemaking would be subject to the abstention bar. ${ }^{284}$

On the other hand, if agency rulemaking challenged on reasonableness grounds presented an appropriate occasion for abstention, agency lawmaking would escape federal court review to a greater extent than lawmaking by city councils and state legislatures, whose acts are routinely subject to federal court scrutiny on federal grounds. And the escape from review would be without congressional authorization as provided in the Tax and Rate Injunction Acts. Allowing due process reasonableness challenges to nonfederal agency rulemaking to be treated as raismg viable federal questions also has the advantage of consistency with Parratt, which still permits federal court challenges to legislation and other systemic state action. Given the combination of a minimal rationality standard and the requirement of a substantial federal question, allowing systemic challenges to the reasonableness of agency action is unlikely to open the jurisdictional floodgates in the same manner that allowing ad hoc challenges would. If the federal claims proved insubstantial, they could smiply be dismissed on the inerits. ${ }^{285}$ And, of course, they would be subject to the same sorts of limitations to which all other $\S 1983$ actions are subject. ${ }^{286}$

\section{B. Challenges Beyond Administrative Unreasonableness}

For challenges to agency action on federal law grounds other than reasonableness, the Court's older default rules have largely remained in place, despite mstances of Supreme Court wavering and lower court confusion. The modern rehabilitation of $\S 1983$ has reinforced these default rules. ${ }^{287}$ It is still possible, for example, to challenge most final legislative action (mcluding agency rulemaking) ${ }^{288}$ in federal court when

284. Moreover, as with ad hoc deprivations of due process interests that have generally not been federalized, the federal rationality standard will, for the most part, be within the compass of state standards of review.

285. If federal question jurisdiction were the only basis for access to a federal court, any pendent state claims could be dismissed without prejudice under 28 U.S.C. $\$ 1367$ (c) (1994).

286. See infra text accoinpanying notes 288-295. This approach-excluding nost ad hoc arbitrariness claims against agency action but allowing for systemic challenges-may explain the result in District of Columbia Court of Appeals v. Feldman, 460 U.S. 462 (1983), in which allegedly unreasonable bar regulations (promulgated by judicial officials acting in a legislative capacity) could be prospectively attacked by proper parties in a lower federal court, even though an ad hoc demal of bar admission challenged on arbitrariness grouuds could not. See supra note 160 (discussing Feldman).

287. For an effort to explain the modern resurrection of $\S 1983$ after a long period of dormancy, see Collins, supra note 152, at 1497-1507; see also Louise Weimberg, The Monroe Mystery Solved: Beyond the "Unhappy History" Theory of Civil Rights Litigation, 1991 BYU L. REV. 737 (1991) (pinning $\S 1983$ 's dormancy to the delayed incorporation of Bill of Rights guarantees through the Fourteenth Amendment's Due Process Clause).

288. See New Orleans Pub. Serv., Inc. v. Council of City of New Orleans, 491 U.S. 350, 365 (1989). 
the challenge is based on federal law or the Constitution. And at least since Ex_parte Young, ${ }^{289}$ which allows prospective relief against state officers, suits for injunctive relief have been brought in federal court without running afoul of the barrier of sovereign immunity. In addition to agency rulemaking, final agency action of an executive nature (sometimes categorized as informal adjudication) is also subject to constitutional challenge, ${ }^{290}$ as is the executive action of other state and local officials. Thus, apart froin administrative unreasonableness claims, federal courts are ordinarily available for mounting a federal-law challenge to final legislative and executive action by an agency, in contrast to certain judicial-style proceedings (especially agency enforcement proceedings). ${ }^{291}$

289. 209 U.S. 123 (1908) (involving a challenge to legislatively set rates).

290. See, e.g., Cleavinger v. Saxner, 474 U.S. 193 (1985) (involving a decision of a prison disciplinary committee); Pickering v. Board of Educ., 391 U.S. 563 (1968) (involving a decision of a school board); Alleghany Corp. v. Haase, 896 F.2d 1046 (7th Cir. 1990) (involving the denial of a certificate by a state insurance commission), vacated on grounds of mootness and res judicata sub nom. Dillon v. Alleghany Corp., 499 U.S. 933 (1991); cf. Suituin v. Tahoe Reg'1 Planning Agency, 117 S. Ct. 1659 (1997) (allowing for the possibility of a federal court regulatory-takings challenge to an agency's decision disallowing a landowner to develop land).

291. Judicial-style remedial administrative proceedings-proceedings invokcd by a regulated party to remedy some past act of a state or local official-can present a different picture. Although litigants under $\S 1983$ are not obliged to exhaust administrative remedies as a precondition to filing suit, see Patsy v. Board of Regents, 457 U.S. 496 (1982), a regulated party's choice to pursue administrative remedies first may, in some settings, effectively foreclose later consideration by a federal trial forum. Voluntary pursuit of such remedial agency action may, according to the Court, effectively lock the claimant into adjudication by the state system if the proceedings prove to be "judicial in nature." University of Tenn. v. Elliott, 478 U.S. 788, 799 (1986) (prescribing preclusion as to factual findings of an agency acting in a judicial capacity); $c f$. District of Colunbia Court of Appeals v. Fcldman, 460 U.S. 462, $477-78$ (1983) (pennitting direct review, not collateral federal court imtervention following final judicial action of a state court system); Rooker v. Fidelity Trust Co., 263 U.S. 413 (1923) (same). But see infra text acconipanying notes 317-340 (critiquing Elliott). Administrative enforcement actions that are "judicial in nature" will also generally lock regulated parties into the state court systen. See Middlesex County Ethics Comm. v. Garden State Bar Ass'n, 457 U.S. 423, 432-35 (1982) (applying the equitable restraint principles of Younger v. Harris, 401 U.S. 37 (1971), to prevent a federal constitutional challenge to the bar disciplinary rules under which a defendant to state bar proceedings was being prosecuted); see also Huffman v. Pursue, Ltd., 420 U.S. 592 (1975) (concluding that judicial review of an enforcement proceeding is also subject to the strictures of Younger). Obviously, the invocation of state agency process in the enforcenient context is not voluntary from the perspective of the regulated party. But principles of "equity, comity and federalism" are thought to warrant nonintervention into state enforcement proceedings just as with criminal prosecutions-including state judicial review of them. But cf. Gibson v. Berryhill, 411 U.S. 564 (1973) (allowing an injunction agamst an optometry license revocation liearing upon a showing of economic bias of the administrative tribunal). Finally, sone judicial-style proceedings may be noncoercive in nature (sucl as the permitting deeision by the zoning board in City of Chicago $v$. International College of Surgeons, 118 S. Ct. 523 (1997)), and also nonremedial, in the sense that the agency proceeding does not seek to reniedy any past harm. As discussed in the text, we argue for the ability of federal courts to review sucl proceedings when jurisdiction is otherwise present, and, as with the reinedial proceedings associated with the deeision in Elliott, we argue against the application of strict preclusion in such settings. 
That review inay also be had in the state courts on either state-law or federal-law grounds has generally not prevented regulated parties froln immediately attacking the constitutionality of agency action in either an injunctive or declaratory action in federal court. The possible arguinent that the state has soinehow not finally acted until state courts have been allowed to pass on the lawfulness of the agency's actions as a matter of state law was dispatched long ago, both as a constitutional ${ }^{292}$ and a statutory ${ }^{293}$ matter. Thus, apart froin certain kinds of judicial agency decision making, ${ }^{294}$ a state's use of agencies does not ordinarily provide an escape from federal challenges that could be mounted to such activities in non-agency contexts. ${ }^{295}$

Nevertheless, when the Court in New Orleans Public Service, Inc. v. Council of the City of New Orleans ${ }^{296}$ considered Burford abstention in a federal court constitutional challenge to agency decision making, it hedged its language while denying abstention. The Court pointed out that it was dealing with a facial challenge (on Commerce Clause and preemption grounds) to a regulatory body's legislative action that excluded costs of an out-of-state nuclear plant from a utility's rate-base. It therefore concluded that the bulk of the challenge did not involve "local regulatory facts."297 The Court's implicit suggestion was that such facts might have presented a better case for abstention. Even as to that part of the federal-law challenge that could not be resolved on the

292. See Home Tel. \& Tel. Co. v. City of Los Angeles, 227 U.S. 278 (1913) (noting that state action under the Fourteenth Amendment could be present even when local officials acted contrary to state law).

293. See Monroe v. Pape, 365 U.S. 167 (1961) (noting that officials could act "under color of" state law for purposes of $\S 1983$ even when they acted in violation of it), overruled in part on other grounds by Monell v. Department of Soc. Servs., 436 U.S. 658 (1978).

294. See supra note 291; infra text accoinpanying notes $317-340$.

295. Some scholars have attempted to justify Burford abstention by linking it to the doctrine of equitable restraint in Younger v. Harris, 401 U.S. 37 (1971), which bars federal court interference with ongoing state enforcement proceedings, including appellate review of them. See, e.g., Friedman, supra note 2, at 540; Massey, supra note 120, at 832, 834-43; cf. infra note 343 (noting apphication of Younger by some federal courts to nonenforcement proceedings, such as licensing). Both settings are said to involve important state interests above and beyond the interest im providing a forun for private hitigants in more ordinary settings, and, in both settings, outright disurissal was the Court's response. Admittedly, ongoing agency-enforcement proceedings (and their later review in the state system) inplicate concerns similar to Younger's, and therefore warrant federal court abstention. But other agency proceedings, as a rule, do not. Even if the combination of multi-branch functions in a single entity can sometimes suggest a greater state regulatory interest than that which exists in the operation of the state's common law, it hardly rises to the level of interest associated with state court enforcement of criminal or other public law norms. Even in the crimimal-law context, federal courts are usually able to interfere by way of injunctive and declaratory relief in the absence of state court enforcement proceedings, and through habeas corpus after state court proceedings have terminated. See HART \& WECHSLER, supra note 3, at 1516-20 (discussing availability and timing of federal court interference with state criminal proceedings).

296. 491 U.S. 350 (1989).

297. See id. at 363-64. 
face of the rate order, moreover, the Court observed that the necessary factual inquiry did "not demand significant familiarity with, and will not disrupt state resolution of, distinctively local regulatory facts or policies." 298 A concurring opinion also indicated that things might have come out differently had there been a "specialized" state court to which appeals were channeled. ${ }^{299}$ Thus, administrative abstention appears to remain a possibility even in federal question cases calling for heightened scrutiny if such factors as a complex regulatory scheme, "local facts," or a single specialized tribunal for review exist. ${ }^{300}$

\section{The Impact of Complexity and Specialization}

\section{Uniformity and Agency Fact-Finding}

The focus on uniformity and fact-finding ${ }^{301}$ generally reflects the worry that federal courts might not decide issues relating to state agency action-particularly factual issues-as would state institutions. As a general inatter, and as we have noted, ${ }^{302}$ there is little arguinent outside of the Burford setting that federal court fact-finding should mimic a state court's, whether jurisdiction is grounded on diversity or the presence of federal questions. Erie's call to uniformity primarily relates to the construction of state law and its application. That federal courts might determine facts differently froin state courts $\mathrm{m}$ most settings is the unprobleinatic result of providing an alternative, neutral forum. The agency context, however, arguably presents a stronger claim for

298. Id. at 364 .

299. See id. at 374 (Rehnquist, C.J., concurring); cf. id. (Blackmun, J., concurring) (finding majority's general understanding of Burford abstention "much narrower than my own"). This should be less of a consideration for local agencies than for state agencies. While appeals may go from local agencies to particular state courts by virtue of geography, such reviewing courts are unlikcly to be truly specialized. Even at the state-agency level, the "specialized" court may merely be the one that happens to be in the vicinity of the state agency-often the district of the state capitol (as in Burford).

300. Even in its recent decision in City of Chicago v. International College of Surgeons, $118 \mathrm{~S}$. Ct. 523 (1997), upholding jurisdiction over a pendent state-law claim involving deferential review of a local zoning board, the Court left open the possibility of abstention on remand, although it did not indicate the possible basis for such abstention or whether it would apply to the federal as well as the state claims in the case. The dissentcrs chided the majority over its unwillingness to be specific, asking rhetorically whether the Court would invent a doctrine of "Chicago abstention." Id. at 541 (Ginsburg, J., joined by Stevens, J., dissenting). Lower courts have sometimes relied on the language of limitation in decisions such as New Orleans Public Service to bar, on Burford grounds, challenges to state-ageney action involving federal issues that would mcrit inore than ad hoc reasonableness review. See, e.g., Sierra Club v. City of San Antomio, 112 F.3d 789, 797-98 (5th Cir. 1997) (ordering abstention because of the coinplexity of a state agency's water regulation scheme, despite allegations that the agency acted in violation of the Endangered Species Act, 16 U.S.C. $\$ 1540$ (c) (1994)), cert. denied, 118 S. Ct. 879 (1998); Pomponio v. Fauquier County Bd. of Supervisors, 21 F.3d 1319, 1327 (4th Cir. 1994) (adopting virtual per se rule requiring abstention in challenges to land use or zoning orders); see also sources cited supra note 266.

301. To the extent that these considerations express concerns about uniformity of state law, we have addressed them above. See supra text accompanying notes 220-261.

302. See supra text accompanying notes $240-250$. 
uniformity in fact-fnuding and state exclusivity. ${ }^{303}$ After all, providing for greater uniformity in decision making was among the initial rationales for concentrating decision making in specialized agencies, and such uniformity might well enconpass fact-finding. ${ }^{304}$ Uniform fact-finding might also be thought to result fron the "neutral" expertise agencies supposedly offer. ${ }^{305}$ Finally, albeit perhaps soniewhat contradictorily, uniformity in fact-finding could result from a supposedly desirable proregulatory or other political agency bias.

\section{a. State-Law Fact-Finding}

In the area of state-law as opposed to federal-law causes of action, the federal courts' applicatiou of the same deferential standards of review that the state courts apply substantially addresses the concern for uniformity in fact-finding. Application of deferential fact-review standards would in most instances lead both state and federal courts to uphold state agency fact-findings so long as there is substantial evidence in the record to support them. There seeins to be little reason to believe that federal courts cannot perform this policing function as "accurately" as state courts-even specialized state courts. This is especially true when one factors in the potential for local bias. ${ }^{306}$ It might be argued that the federal courts would be less efficient (and accurate) than specialized state courts in understanding the possibly unfamiliar details of a coniplex regulatory scheme. ${ }^{307}$ But some loss of efficiency is built into the congressioual provision for jurisdictional choice that nonresidents (and federal rights claimants) inay exercise. And it is not clear that time-savings or efficiency concerns by themselves coustitute proper grounds for declining jurisdiction. What is more, abstention and

303. See, e.g., Field, supra note 2 , at 1157 (suggesting that factual complexity might justify abstention as to federal issues).

304. Application of law to fact may have been the primary concern behind the uniformity rationale for agencies. For example, worker compensation boards were pervasive early agencies and there may have been a desire for uniform, employee-sympathetic treatment on issues such as scope of employment. See LANDIs, supra note 100, at 30-38, 46.

305. See Field, supra note 2, at 1156-57 (stating that the concentration of judicial review may mean that a state court has developed subject-matter expertise and may participate more in formulating regulatory decisions, and that the state values uniformity, but that these rationales would not necessitate abstention without regard to the clarity of the state issues). See generally HoRwitz, supra note 100, at 241 (chronicling the delegitimation of the expertise theory).

306. Even were a state court truly specialized, but cf. supra note 299 , it is difficult to believe that a specialized court adds mucl when fact review is deferential. More likely the specialized court, to the extent it contributes to policy development, does so by deciding issues of law and applying law to fact. To the extent that a special court achieves its presumed goal of providing uniformity, its results should be imitable by the post-Erie federal courts.

307. See, e.g., Bezanson, supra note 2, at 1123-24 (observing that state courts would be "more able and efficient" than federal courts in resolving matters in which they have developed law-making and fact-finding expertise). 
certification generate their own inefficiencies. ${ }^{308}$ Yet if the risk of error will generate substantial collateral fallout along the lines that we have described, ${ }^{309}$ abstention should still be an option.

\section{b. Federal-Law Fact-Finding}

In the context of federal challenges, the argument for abstention based on uniformity concerns is even weaker. Expertise of the agency or even the state courts with respect to questions of law is ordinarily not implicated when the questions are of federal law. ${ }^{310}$ In many federal-law challenges to state action, therefore, deference and uniformity-of-law concerns are largely beside the point. "Dil "Disruption" of a state regulatory program simply because a federal court might conclude that the agency has acted in violation of federal law is a familiar cost associated with the Supremacy Clause and $\S 1983$, and by itself ought not to provide a basis for abstention. ${ }^{312}$

Nor does the desire for uniformity in fact-finding as to matters in which federal law is applicable seein a compelling reason for abstention. ${ }^{313}$ Favoring state over federal fact-finding with respect to stateagency decision making that implicates, for example, religious freedoms or racial discrimination, stands the expertise argument on its head.

308. See Lehman Bros. v. Schein, 416 U.S. 386, 394 (1974) (Rehnquist, J., concurring) (noting competing mefficiencies involved in certification of unclear state-law questions); Currie, supra note 2, at 317 (noting costs as well as benefits of certification, but concluding, "I think I should prefer to let the federal courts muddle through murky state law on their own, in the interests of judicial economy ..."); see also Thermtron Prods., Inc. v. Hermansdorfer, 423 U.S. 336, 344 (1976) (noting that the suggestion that the federal court was "too busy" was no reason for remanding a properly removed case). But cf. Colorado River Water Conservation Dist. v. United States, 424 U.S. 800, 81718 (1976) (noting that efficiency concerns inay be a proper consideration in the exercise of abstention in deference to parallel state court litigation).

309. See supra text accompanying notes 234-239.

310. Claims addressed to the ad hoc reasonableness of state action-which, as we have noted, may be heavily dependent on the interpretation and application of state law iu a nondiversity setting are a possible exception.

311. And if an in-stater joins a pendent state-law claim, the federal court could decline to exercise its supplemental jurisdiction under the standards of 28 U.S.C. § 1367(c) (1994).

312. The Court has rightly observed that abstention is not called for just because there is an administrative process or "in all cases where there is a 'potential for conflict' with state regulatory law or policy." New Orleans Pub. Serv., Inc. v. Council of City of New Orleans, 491 U.S. 350, 362 (1989) (quoting Colorado River, 424 U.S. at 815-16); see also Zablocki v. Redhail, 434 U.S. 374, 380 n.5 (1978) ("[T]here is ... no doctrine requiring abstention merely because resolution of a federal question may result in the overturning of a state policy.").

313. See Friedman, supra note 2, at 551 (arguing that abstention is less appropriate when the federal right turns on a question of fact). But see Fair Assessment in Real Estate Ass'n v. McNary, 454 U.S. 100 (1981) (suggesting that comity-based abstention arising out of the Tax Injunction Act might not be appropriate $\mathrm{m}$ a $\S 1983$ action for unconstitutionally assessed taxes if the suit had raised a facial challenge). If the presence of supposedly complex factual issues were to pose a barrier to federal court review, then litigants might get around Burford only in the fairly rare setting in which a party could present a facial challenge to the agency's action, as was true, in part, in New Orleans Public Service. 
Absent some sort of preclusion arising from certain kinds of judicial agency decision making (as discussed below), federal courts should not only be able to take jurisdiction of such claims, but should arguably provide the de novo review of fact that is characteristic of $\S 1983$ actions more generally. Indeed, an important rationale for federal question jurisdiction is to provide a forum hospitable to federal rights, and such hospitality (as with diversity) extends to both facts and law. ${ }^{314}$

Although agency action challenged on constitutional grounds presumptively should be subject to de novo review of fact, even this presumption bears qualification given the varieties of agency action. The relevant constitutional standard, for example, may itself call for a high degree of deference that can also extend to facts, particularly legislative facts. Thus, were a regulated party to challenge an agency rule of general applicability on grounds implicating rational-basis scrutiny, federal courts would customarily presume the existence of supporting legislative facts. ${ }^{315}$ Analogously, less deference to legislative fact-finding inight typically accompany constitutional claims warranting a closer look at state legislation or rulemaking.

314. Professor Martin Redish has argued that, when agency action is challenged on federal grounds, abstention should be available only when (1) the regulatory program is of "significant concern to the state;" (2) the regulatory scheme is "in fact detailed and complex;" and (3) when "the federal issue cannot be resolved without requiring the federal court to immerse itself in the technicalities of the state scheme." MARTIN H. REDish, FEdERAL JuRISDiction: TENSIONS IN THE Allocation of Judicial Power 137 (2d ed. 1990); see also Chemerinsky, supra note 5, \$ 12.2.3, at 759-60 (endorsing Redish's formulation). It is likely, however, that the first factor will always be true. Cf. Clark, supra note 2, at 1533 (imdicating post-Erie skepticism over whether one public policy problem can be gauged to be of greater "importance" than another). Similarly, it will often be possible to make the detailed/complex-regulatory-scheme argument, especially when "local" factual issues are involved, as they might be in any nonfacial challenge to the agency's action. $C f$. Wells, supra note 2, at 76 (noting that what is and is not local is not a helpful distinction). The last concern noted by Professor Redish may be a relevant consideration, but the inost obvious illustrations of undesirable "immersion" into state regulatory schemes will involve attacks on agency actions on reasonableness grounds. To the extent that his third category would operate to bar federal-law challenges on nonreasonableness, such as a preemption or First Amendment challenge, we disfavor abstention, for reasons discussed in the text. Interestingly, when challenges to state agency decision making implicate legal rather than equitable relief, concerns about "inportance," "complexity," and the like may all be equally implicated, but they might not pose a barrier to federal court relief. See Quackenbush v. Allstate Ins. Co., 517 U.S. 706, 729-31 (1996) (noting that federal courts lack power to remand or dismiss when rehef sought is nondiscretionary). Compare id. at 732 (Scalia, J., concurring) (seeing majority opinion as closing door on abstention in nonequitable relief cases), with id. at 733-34 (Kennedy, J., concurring) (seeing door still ajar).

315. See Pacific States Box \& Basket Co. v. White, 296 U.S. 176, 186 (1935) (noting the presumption, attached to agency action, of the existence of facts to justify regulation); $c f$. Williamson v. Lee Optical, Inc., 348 U.S. 483, 491 (1955) (hypothesizing legislative fact-finding in a rationalbasis attack upon a state statute on Due Process and Equal Protection grounds). This deference contrasts with the more searching statutory review of federal agency rulemaking under the Admimistrative Procedure Act, 5 U.S.C. $\$ \$ 701-706$ (1994). See generally BREYER ET AL., supra note 185 , at 345-413 (discussing the "hard look" doctrine). 


\section{Finality and Agency Adjudication}

Agency action that could be considered adjudicatory presents special problems for later-litigated $\S 1983$ actions. Agency adjudicatory fact-finding implicating federal rights, however, will more likely raise issues of preclusion and finality rather than uniformity. ${ }^{316}$ In University of Tennessee $v$. Elliott, ${ }^{317}$ an agency hearing that resulted in a factual finding that a state university did not racially discriminate against an employee was given preclusive effect in a later-decided $\S$ 1983 action brought by the employee. The Court stated that if a state agency, "'acting in a judicial capacity," resolved factual issues that the parties had "an adequate opportunity to litigate" before the agency, then primciples of comity ${ }^{318}$ required federal courts to give the agency's fact-finding the same preclusive effect to which it would be entitled in the state courts. ${ }^{319}$

Writing from a clean slate, and without Elliott, it imight be desirable to maintain $\S 1983$ challenges to state action as de novo, absent anything other than genuinely court-based state decision making. ${ }^{320}$ As noted in our argument against treating judicial review of agency action as "appellate," agency adjudication can and should be distinguished from any later "judicial" phase in the regular court system. The Court in Elliott itself recognized an agency-adjudication/court-adjudication distinction by holding that the full faith and credit statute was not directly applicable to agency adjudication. ${ }^{321}$ Nevertheless, its breezy conclusion that unreviewed state agency judicial proceedings should be given the same preclusive consequences as the states would give them bears qualification.

316. State-law challenges to state agency action generally do not present a preclusion problem in the strict sense. Because federal review substitutes for state court review, the issuc tends to be one of applying the same standard of deference as would a state court. See supra text accompanying notes 174-219.

317. 478 U.S. 788 (1986).

318. See id. at 796-98 (quoting United States v. Utah Constr. \& Mining Co., 384 U.S. 394, 421-22 (1966)).

319. See id. at 799.

320. Indeed, given the extensive nature of the hearing in Elliott, the fact that the employec did not need to pursue agency proceedings as a precondition to federal relief under $\S 1983$ for the harm that he had already suffered, and that he was accorded some rehef in the state system, the Court may have considered his case to be one in which the higant received process as good as or better than most regular courts would give.

321. See Elliott, 478 U.S. at 798-99. By finding that preclusion was comity-driven rather than the result of the full faith and credit statute, the Court implicitly concluded that judicial-style agency procecdings were not the "judicial proceedings of any court" to which the full faith and credit statute speaks. See 28 U.S.C. § 1738 (1994). 


\section{a. Not-So-Formal Adjudication}

First, the Court's admonition failed to take account of the varieties of agency judicial process. ${ }^{322}$ A state agency's proceedings might be conducted under standards resembling those for so-called "formal adjudication" under the federal Administrative Procedure Act and state acts patterned on $\mathrm{it}^{323}$ - a model that the Court may have had in mind in Elliott. Alternatively, state agency proceedings might fall into a range of somewhat less formal adversary hearings that are on-the-record and have certain trial-like characteristics. ${ }^{324}$ Although both may be "judicial in nature" and wear the statutory tag "adjudication," it is doubtful whether their finality should be treated similarly.

Elliott's preclusion rule probably ought not to apply to the more informal adjudicatory hearings of the second category, and actions following such proceedings probably should proceed de novo. ${ }^{325}$ Some lower courts, however, appear to have read Elliott as allowing preclusion even for such minimally judicial proceedings as school board hearings held in connection with the termination of an einployee, ${ }^{326}$ or comparable informal hearings that happen to comport with the basic guarantees of procedural due process. ${ }^{327}$ In the past, the Supreine Court has

322. This failure may have led the Court to back down a bit in Astoria Federal Savings \& Loan Association v. Solimino, 501 U.S. 104 (1991). See infra note 333.

323. See Uniform Law Commissioners' Model State Administrative Procedure ACT $\S$ 4-201 to -221, 4-301 to -403 (1981); see also Asmow ET AL., supra note 200, at 176 (noting that most states follow the federal model of hiring their own administrative law judges while the agencies retain power to make final "adjudicatory" decisions). Of course, in exceptional cases, an agency may effectively be considered the equivalent of a regular court, in which case $\S 1738$ would apply by its own terms.

324. See Asmow ET AL., supra note 200, at 93-94, 97-100 (discussing different types of hearings).

325. States themselves are unlikely to accord the decisions of such bodies a judicial-like preclusive effect, so that Elliott will not operate by its own terms. But preclusion ought not to operate even if the states tried to give it, under the traditional preclusion principle that reduced procedural opportunities can serve to deny preclusion. See Restatement (SECOND) of JudGments $\$ \S 28(3)$, 29(1)-(2) (1982). But cf. AsIMOW ET AL., supra note 200, at 205-08 (discussing state court decisions giving preclusion to agency adjudication).

326. See Thomas v. Contoocook Valley Sch. Dist., 150 F.3d 31 (1st Cir. 1998) (recognizing that "courts have differed in their treatment of the preclusive effect accorded to factual findings by school boards acting in quasi-judicial capacities im subsequent suits alleging discrimination"); see also, e.g., Hall v. Marion Sch. Dist, 31 F.3d 183, 190-92 (4th Cir. 1994) (noting that a school board's termination decision was not preclusive of a $\$ 1983$ action challenging it, but ouly because the federal district court had concluded that there was "actual bias" on the part of the board); Gahr v. Trammel, 796 F.2d 1063, 1069 (8th Cir, 1986) (appearing to leave open, in light of Elliott, whether unreviewed school board learings might be issue-preclusive in a later $\$ 1983$ action).

327. Compare, e.g., Miller v. County of Santa Cruz, 39 F.3d 1030 (9th Cir. 1994) (holding that findings on questions of law by a county civil service commission, which was not governed by the state administrative procedure act and consisted of nonlawyers, were issue-preclusive in a later $\S$ 1983 action) and Long v. Laramie County Community College Dist., 840 F.2d 743 (10th Cir. 1988) (holding that findings of a state college grievance committee regarding sexual harassnient were issue preclusive in a later $\S 1983$ action), cert. denied, 488 U.S. 825 (1988), with, e.g., Kleenwell 
routinely assumed that no preclusion would attach to such gardenvariety hearings performed by local governments. ${ }^{328}$ It has even allowed the individual decision makers in such hearings to be subject to $§ 1983$ damages suits for their unconstitutional actions. ${ }^{329}$ In so doing, it has not accorded these actors judicial immunity merely because their actions were restrained by constitutional guarantees of fair procedures.

The refusal to accord judicial immunity to this category of agency proceedimgs comes not merely from their reduced formality; indeed, the level of formality may sometimes be difficult to distinguish from the Administrative Procedure Act-style cases of formal adjudication. ${ }^{330}$ Rather, the lack of neutrality and independence, as well as the absence of traditions of judicial professionalism, ${ }^{331}$ also argue against treating agency officers as comparable to judges. ${ }^{332}$ Indeed, since Elliott, the Court arguably has tempered its common law of agency-preclusion by declining to give preclusive effect to unreviewed state agency findings regarding age discrimination. ${ }^{333}$

Biohazard Waste and Gen. Ecology Consultants, Inc. v. Nelson, 48 F.3d 391 (9th Cir. 1994) (reaching the merits in a $\S 1983$ challenge to a certification requirement imposed by the Washington Utilities Commission), and Edmundson v. Borough of Kennett Square, 4 F.3d 186 (3d Cir. 1993) (holding that a finding by an administrative agency consisting of laypersons was not binding in a later First Amendment challenge to the agency's action under $\S 1983$ ).

328. It is instructive that (before Elliott, at least) the Supreme Court in $\S 1983$ actions never bothered to inquire into the treatment that the states would give such hearings. See, e.g., Migra v. Warren City Sch. Dist. Bd. of Educ., 465 U.S. 75 (1984) (focusing on the preclusive consequences of state court review of a school board's action, not on the preclusive consequences of the board's action itself); see also infra note 335 (discussing preclusion).

329. See, e.g., Cleavinger v. Saxner, 474 U.S. 193, 203 (1985) (noting that a prison's lnmate Disciplinary Committee, although it "perform[s] an adjudicatory function," was not cntitled to absolute judicial immunity in a $\$ 1983$ damages action for the punishınent of a prisoner); Wood $\mathrm{v}$. Strickland, 420 U.S. 308, 319 (1975) (rejecting absolute judicial immunity for school board members sued in a $\S 1983$ action over discipline meted out to a student after a formal hearing, although noting that they performed as "adjudicators").

330. There will often be written procedures for such hearings, but they will generally lack the protections of neutrality of the decision maker or at least some modicum of separation of functions that typify formal adjudication under state administrative procedure acts.

331. See Cleavinger, 474 U.S. at 201-04.

332. To accord preclusive effects to the decisions of officials whose actions would not receive judicial immurnty were they sued individually could effectively make them judges in their own cases. By contrast, a finding of judicial immunity in the individual actor, such as a state adıninistrative law judge, might be relevant (although not conclusive) in deciding whether agency proceedings are sufficiently judicial that soine kind of finality could attach to their outcomes.

333. See Astoria Fed. Sav. \& Loan Ass'n v. Solimino, 501 U.S. 104 (1991). The Court did so despite the absence of clear congressional language excluding the application of preclusion to such findings. Nevertheless, Astoria seems to proceed as though the agency proceedings would have been sufficiently judicial, and subject to preclusion, in the absence of congressional policy to the contrary. See id. at 108-09 (stating that Elliott's rule was presunptive, subject to congressional displacement). 


\section{b. Formal Adjudication}

It is then, in the other category-where agency process is adjudicatory under APA-like formal hearing standards-that Elliott raises difficult questions of issue preclusion, at least when agency decisions would have preclusive effect under state law. ${ }^{334}$ Elliott involved a decision in which the litigant did not seek review of the state agency's decision (and a reviewed decision clearly would have had preclusive effect under the full faith and credit statute). ${ }^{335}$ But its proper reach might be better analyzed by looking at what might have happened had a litigant brought both a state-law review action and a parallel $\S 1983$ or other federal-law challenge in the same federal court proceeding attacking local agency action. ${ }^{336}$ As we have argued, the federal courts can conduct state-law statutory review of agency action just as the state courts can, and College of Surgeons would allow for bringing both a federallaw and a state-law challenge together ${ }^{337}$ Sitting as a state court in the state statutory review proceeding, the federal court would not apply preclusion to the state fact-findings; rather, the federal court presumably would give the state fact-findings the same deference or finality that the state courts would on direct review. ${ }^{338}$

334. Presumptively, state-wide agencies with procedures like those in the Model State Administrative Procedure Act, that included Administrative Law Judges (ALJs) with separation of functions would be in this other category. See Uniform Law Commissioners' Model State Administrative Procedure ACT \$ 4-214 (1981). In contexts outside of the formally adjudicative, the fact that the state might give preclusive effect to an unreviewed agency determination does not seen to lead anywhere analytically. Informal actions could, for example, become final if unreviewed, although the Court im Astoria did not see that as conclusive in an age discrimination case.

335. Before Elliott, the Court held that when a state agency determination had been reviewed by a state court, a federal court would have to give preclusive effect to the later judicial determination. See, e.g., Migra v. Warren City Sch. Dist. Bd. of Educ., 465 U.S. 75 (1984); Kremer v. Chemical Constr. Corp., 456 U.S. 461 (1982). Elliott, of course, went further by concluding that a federal court would respect a state determmation to give preclusive effect to unreviewed agency judicial proceedings.

336. Although, given Pennhurst State School \& Hosp. v. Halderman, 465 U.S. 89 (1984), sovereign immunity would likely have barred the plaintiff in Elliott froun bringing a state-law statutory review action against a state university or its officials in federal court, he might bave been able to join a state review action and the $\$ 1983$ action (or a federal-law grounded state-law statutory review clain, as in College of Surgeons, see infra note 337) in a state court action. In those circumstances, as in the federal court example in the text, the state court likely would have some latitude to review agency fact-finding. See UNIForm LaW Commissioners' Model State Administrative Procedure ACT \$ 5-116(c)(7) (1981).

337. See supra text accompanying notes 210-212. In City of Chicago v. International College of Surgeons, 118 S. Ct. 523 (1997), the party seeking review brought a state statutory review action raising federal and state challenges. The Court treated the claim as a cause of action under state law, in which the right to rehef, on the face of the wcll-pleaded conplaint, depended on the resolution of a substantial issue of federal law, and thus allowed removal. The text addresses the related issue of whether a $\$ 1983$ action could be brought as well. Our hypothetical assumes that the federal court would not declime to exercise jurisdiction over the pendent state-law claim.

338. The state-court judicial review action would also ordinarily encompass issues related to the violation of federal statutory and constitutional law (as to which no deference would ordimarily be 
As to a possible $\S 1983$ action to which the state action might be appended, it seems counterintuitive to suppose that the federal court would give the agency-found facts greater finality than they would receive in the federal court state-review action. ${ }^{339}$ After all, the whole point of Elliott was to give the agency's findings the effect they would receive in state court. ${ }^{340}$ And it would be doubly odd to suppose that the better route to avoid preclusion in federal court would be to bring a federal challenge to state agency action through a state-created claim (as in College of Surgeons) rather than simply bringing an action under $\S 1983$. Instead, the "preclusion" issue in such settings should turn into whether the federal court (in the federal claim) should give the state agency fact-findings the deference they would receive in the state statutory review claim, or whether it should give them de novo review (including a new evidentiary hearing).

According the same level of fact-finding deference in the federal claim as would apply to the state law claim clearly respects the state agency process and may supply an element of neatness by keeping the standard of review of state and federal fact-findings consistent. ${ }^{341}$ This

due the agency), and which could parallel the $\$ 1983$ claim. See UnIForm Law Commissioners' Model State Administrative Procedure Act § 5-116(c)(1) (1981). The decision in College of Surgeons included a state statutory review claim that raised a federal question-a claim that the Court conceded could have been filed in federal court in the first instance. See supra note 211. Soine statc systems might even allow for the joining of the $\$ 1983$ clain as such, along with the statutory review claim. See, e.g., Rogers v. Desiderio, 58 F.3d 299, 301-02 (7th Cir. 1995) (discussing Illinois practice). Others might call for procceding separately in the state court system with the $\$ 1983$ claim and the statutory review claim. See, e.g., Davenport v. North Carolina Dcp't of Transp., 3 F.3d 89, 96 (4th Cir. 1993) (discussing North Carohina practice).

339. To illustrate: Suppose that the state-review action proceeded in state court, while a $\S 1983$ action that, for whatevcr reason, could not be brought with the state action, was pending in federal court. According to Elliott, the state agency fact-findings might be preclusive in federal court when issued by the agency; but if a state reviewing court found differently before the fedcral court's review, the state-court-found facts would be the facts given preclusive effect in federal court.

340. Given Elliott, one might arguably have to bring the state review action raising the fcderal constitutional challenge to avoid preclusion in the $\$ 1983$ action on the ground that the unreviewed decision became fmal under state law. But the $\S 1983$ aetion and the state action are both actions for "judicial review" of the agency action, although the federal action focuses only on the legality of the action under federal law while the state action may encounpass statc-law and federal-law grounds. See College of Surgeons, $118 \mathrm{~S}$. Ct. at 537 (Ginsburg, J., dissenting) (discussing the possibility of a plaintiff bringing a $\S 1983$ claim rather than the state-law clain raising federal issues). The nonfinality of the fact-findings, however, should perhaps result whether or not the hitigant brings the state statutory review action-partieularly where the state proceeding would be against a state agency and could not be brought in federal court. Then the effect of the agcncy fimding on the federal claims should no longcr be preclusive in the sense of having to be accorded the effect they would have had if the agency findings had not been judicially reviewed at all.

341. If the federal claim is brought as part of the state administrative review action, as in College of Surgeons, the state standards of review of facts would presumably be apphicable. In College of Surgeons, the state apparently allowed a de novo proceeding in connection with facial constitutional challcnges to agency action, so that the state review action in this respect was similar to a $\S 1983$ action. See 118 S. Ct. at 528-29. 
partial finality, moreover, may not seem untoward when the state proceedings are remedial and elective in the sense that the litigant might have imstead pursued a ripe federal claim in federal court (as in Elliott) at the time she chose to pursue agency remedies. ${ }^{342}$ It is more problematic in an initial licensing or permitting context, ${ }^{343}$ however, where governmental action ordinarily cannot be challenged until the agency has acted. Even though the agency's proceedings are voluntarily initiated by the regulated party in those contexts, they are not entirely elective. . $^{344}$

The other option-de novo reconsideration - has the virtue of preserving the federal fact-finding role in $\S 1983$ actions and of inaintaining consistency in the application of $\S 1983$. For federal courts to control the contours of a federal action where the full faith and credit statute is inapplicable would hardly be unthinkable, although Elliott appears to have rejected the option as a default rule. Such a de novo action, unoreover, would not prevent a court from giving appropriate weight $^{345}$ to a prior agency determination that was worthy of respect. There nay, inoreover, be soine settings in which such de novo review is especially necessary. For instance, in a challenge alleging that the agency was driven by a constitutionally impermissible notivation, such as race or political affiliation, the federal court ought to review the facts

342. Even before the Supreme Court concluded in Allen v. McCurry, 449 U.S. 90 (1980), that state court decision making could have issue-preclusive consequences in later $\$ 1983$ litigation, commentators who argued against sucl preclusion often concluded that voluntary presentation of claims to state tribunals might warrant preclusion. See, e.g., Ncil W. Averitt, Federal Section 1983 Actions After State Court Judgment, 44 CoLo. L. REv. 191, 195-96 (1972) (suggesting res judicata should apply if the litigant voluntarily presents constitutional claims); William H. Theis, Res Judicata in Civil Rights Act Cases: An Introduction to the Problem, 70 Nw. U. L. REv. 859, 882 (1976) (same).

343. License revocation proceedings and state court judicial review of them, because of their state-initiated and coercive nature, would presumably be off-limits to the federal courts under Younger v. Harris, 401 U.S. 37 (1971). Some courts have gone even further, lowever, and lave considered judicial review of noncoercive permitting-type decisions to be barred by Younger. Compare Alleghany Corp. v. Pomeroy, 898 F.2d 1314 (8th Cir. 1990) (finding that Younger barred federal court Commerce Clause and preemption based challenge to denial of permission to acquire stock in particular business), with Alleghany Corp. v. Haase, 896 F.2d 1046 (7th Cir. 1990) (commg to the opposite conclusion on similar facts), vacated on grounds of mootness and res judicata sub nom. Dillon v. Alleghany Corp., 499 U.S. 933 (1991). See also HART \& WECHSLER, supra note 3, at 1307 (noting and discussing Pomeroy and Haase). As we have noted above, only the coercive proceedings and state court judicial review of them should be barred by Younger. See supra note 291.

344. See Friedman, supra note 2, at 585-86 (observing that litigants usually do not liave an option to skip the agency process in permitting-type cases, despite the fact that litigants ordinarily need not exhaust state administrative remedies before commencing a suit under $\S 1983$, as was held in Patsy $v$. Board of Regents, 457 U.S. 496 (1982)); see also supra note 291 (anaiyzing possible configurations of judicial-style agency procecdings).

345. See Universal Camera Corp. v. NLRB, 340 U.S. 474, 495 (1951). Sucl a possibility might also help to lessen the problem of having possible pendent claims for review on state-law grounds where the federal court will exercise deferential review. Cf. Beecl Aircraft Corp. v. Rainey, 488 U.S. 153, 170 (1988) (construing FED. R. EvID. 803(8) to allow for a hearsay exception in federal court civil actions for "conclusions" as well as "fact-findings" made in an agency's investigative report, to be given whatever weiglt the federal court fact finder decides to give it). 
de novo, as it would in any claim of executive or legislative illegality. ${ }^{346}$ Issues of an agency's own bias or motivation may not have been actually considered by the agency, and should not be binding even if they had been. ${ }^{347}$ In addition, some constitutional limitations, such as certain First Amendment issues, might require de novo-style constitutional fact review as a matter of federal law, whether judicial review was in state court or federal court. ${ }^{348}$ In this respect, the federal courts would still give only the deference that a state court would (or could) give. Finally, it may often be the case that the states themselves would give less deference (or even none) to a constitutional or federal-law based challenge to state agency decision making, thus obviating the preclusion problem altogether. ${ }^{349}$

In sum, when Elliott is viewed through the lens of possible statestatutory review running alongside the federal action, the maximum effect that the state fact-findings ought to be given as a matter of federal common law is the deference, if any, they would receive under state law. ${ }^{350}$ This result would accommodate state interests in according some measure of finality to formal agency adjudication with federal interests in enforcing federal rights. What is more, an argument can be made in some settings for de novo review in order to preserve federal rights, particularly when (unlike in Elliott) a litigant has not opted for state remedial process when a federal action was already available.

346. That there may be substantial evidence for the agency's decision may be largely irrelevant if it would not have done what it did "but for" the impermissible considerations. $C f$. Mt. Healthy City Sch. Dist. Bd. of Educ. v. Doyle, 429 U.S. 274, 285-86 (1977) (discussing "but for" causation elements in an unconstitutional motivation case). For example, in Hall v. Marion Sch. Dist., 31 F.3d 183 (4th Cir. 1994), a school board's unreviewed finding respecting retaliation against an employec for his exercise of free speech rights was held not to be issue-preclusive in federal court, despite the fact that the board hearing had been a "judicial proceeding." Because the federal court had made a finding of "actual bias" on the part of some meinbers of the board, preclusion was denied, even though the court left the door open, absent such a determination, to finding preclusion in the wake of Elliott. See Hall, 31 F.3d at 191. Judicial challenges to agency procedures as violative of due process would also be de novo. See Withrow v. Larkin, 421 U.S. 35 (1975) (entertaining but rejecting on the merits a challenge to an agency's combination of functions). Perhaps judicial action (in addition to legislative or executive action) that was motivated by constitutionally impermissible considerations could also be the subject of injunctive or related relief. Cf. Gibson v. Berryhill, 411 U.S. 564 (1973) (allowing an injunction against an ongoing optometry lieensing proceeding in which the optometry board would have been inotivated by economic gain to rule adversely to plaintiff).

347. If, as in Elliott, the decision maker who acted on the basis of impermissible motivation is an official whose acts the agency would itself review, then perhaps the aggrieved party ought to have filed a federal action and skipped state agency remedial process altogether.

348. See Bose Corp. v. Consumers Union of United States, 466 U.S. 485 (1984).

349. See, e.g., City of Chicago v. International College of Surgeons, 118 S. Ct. 523, 528 (1997) (noting that the state allowed for a de novo hearing on facial constitutional claims).

350. We suggest this approach even if the litigant did not bring the statutory review action. See supra note 340. 


\section{CONCLUSION}

With Burford and its early progeny, the Court came very close to eradicating from memory the once robust tradition of federal court judicial review of state administrative action. In keeping with the New Deal's larger agenda of reforming federal judicial review, the Court sought to root out not only all vestiges of nonfederal general law (Swift) and its sibling, economic due process (Lochner), but to limit the exercise of federal court jurisdiction that had allowed them to develop. While the Court's implementation of a new set of substantive goals may be understandable enough, its broader effort to curtail federal court judicial review of state administrative action appears to have been an overreaction to the admitted excesses of an earlier, more Nationalist, Court.

As we have argued, the Court was wrong to condemn all aspects of the historical tradition of federal court judicial review of state admimistrative action, despite its association with discredited decisions like Swift and Lochner. First, the old Court's insistence on marking out a divide between administrative action and judicial review-a divide critical to the possibility of federal judicial review-is not inextricably linked to those decisions, and should still be followed. Nor does Erie's recognition of the fluidity of the functions among various branches of state governments, and of the lawmaking role played by state courts, warrant the Burford Court's refusal to recoginze such a divide. Moreover, although the exercise of federal jurisdiction to review administrative action was often im service of now disfavored general law or econormic due process principles, it does not follow that federal courts should refuse to exercise jurisdiction when properly invoked today. The federal courts should continue to honor Congress's jurisdictional commitment to the enforcennent of federal rights and to the provision of a neutral forum for out-of-staters, state efforts to curtail their jurisdiction notwithstanding.

Moreover, as we have argued, the usual reasons trotted out im defense of a diminished federal court role in review of state agency action do not hold up. Insofar as review based on state-law is concerned, the blurring of separation of powers in the wake of Erie does not improperly interject federal courts into state policy making when they review state agency action. Nor does the possibility of such review thrust them unduly into an unfamiliar appellate role; nothing prevents federal district courts from according the same level of review-including deferential standards-as would the state courts. In addition, the post-Erie concern that federal courts might resolve issues of state public law differently than state courts, while real enough, has been overstatedparticularly given the limited nature of judgment-made law. While federal courts can no longer fashion nonfederal general law, there remains 
a legitimate federal interest in insuring a fair forum to out-of-staters, even as to undecided issues of state administrative law. The concern that federal courts not intrude upon a state's power to determine its own public law nnay therefore require abstention only when a misreading of state law would produce class-wide or similar fallout that effectively disables a state from elaborating its own law in the future. Absent such circumstances, we believe that the disadvantages of potentially nonconforming federal court decisions are outweighed by the continuing role of diversity in providing a neutral forum for out-of-staters-not only for the determination of facts, but for the determination of law and for law application as well.

Insofar as federal-law challenges to state administrative action are concerned, we have argued that the decline of economic due process and the accession of fundamental rights calls for careful attention to which claims present appropriate issues for original federal question jurisdiction. On the one hand, we have suggested that federal courts should ordinarily decline to entertain claims that a state agency has acted unreasonably or has applied state law in an arbitrary manner in individual (as opposed to systemic) cases. Many such challenges present only the inost marginal of due process claims (if at all), and they bear a certain resemblance to the low-level due process clainis to which the Court has since denied an original federal forum in Parratt v. Taylor. Limiting the scope of due process in this nuanner helps maintain a reasonable division between state and federal law and, consisteut with the de-einphasis on due process reasonableuess, keeps federal courts from policing state compliance with state regulatory law in nondiversity settings. On the other hand, as to challenges implicating fundamental rights or systemic due process claims, we have argued that final state agency action ordinarily should be no inore immune from federal court challenges based on federal law and the Constitution than any other action of the state or its officials. A threat to federal rights enforcenient in the agency context that is perhaps the equal of abstention is the Court's uncritical application of preclusion principles to state agency decision making. We have therefore argued for reforming those principles so that federal rights claimants are no worse off challenging agency action in federal court than they would be challenging it in state court. 